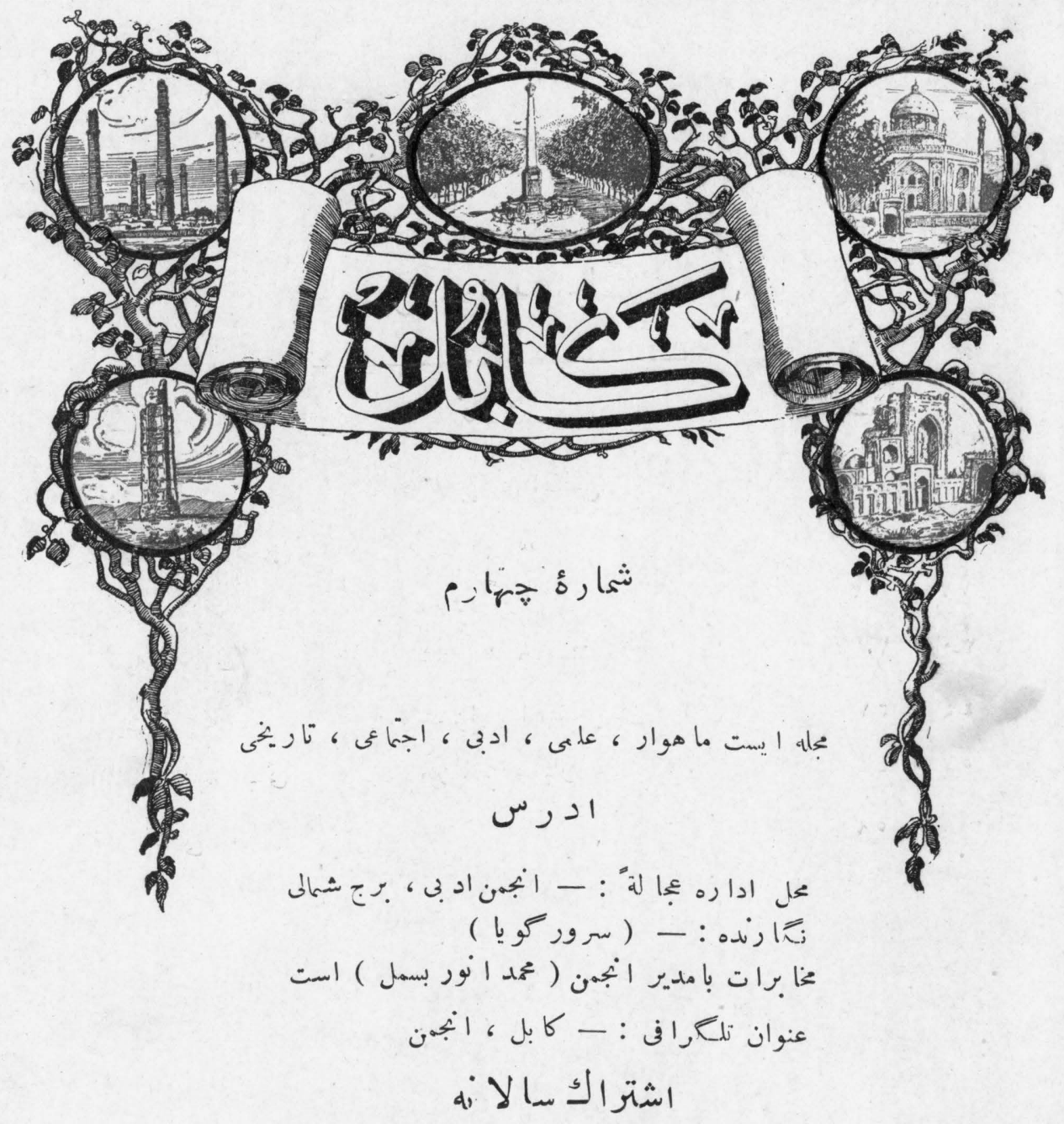

is ك بل

$$
\begin{aligned}
& 12 \\
& \text { مئ عند انعليسى } \\
& \text { رايڤان } \\
& \text { نصف قيمهت }
\end{aligned}
$$

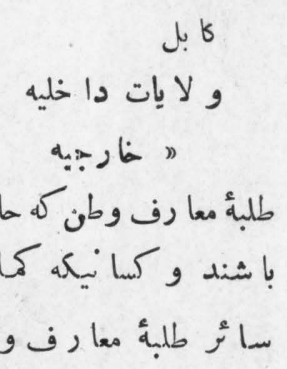

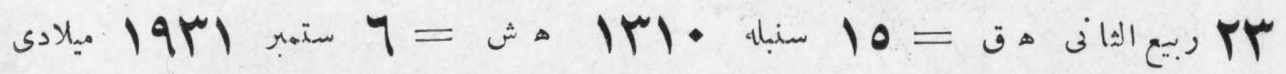




$$
\text { فهرست مندر جات }
$$

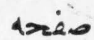

ا الي 11

rI I I

vr" Ir

$r \cdot m r v$

Eะग

o $V \geq \leq \varepsilon$

$\rightarrow A$

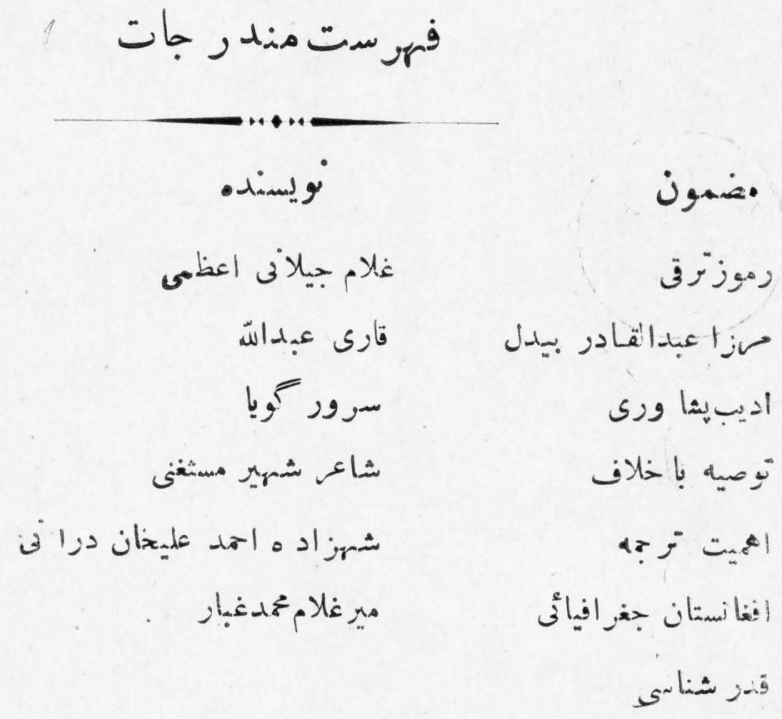

SER
SACKU
S226

$a 02$ 


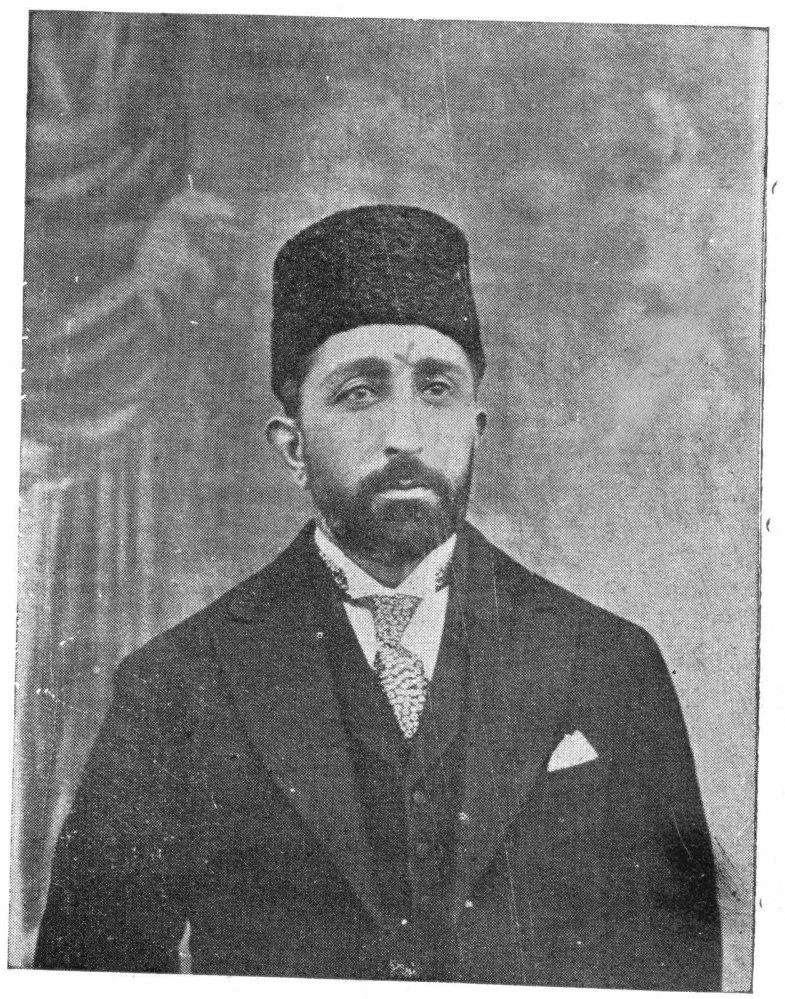

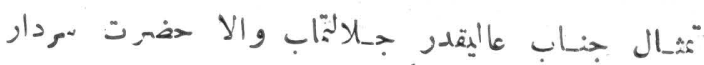

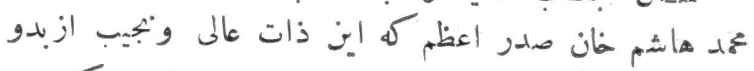

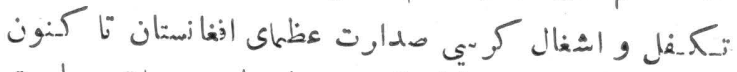

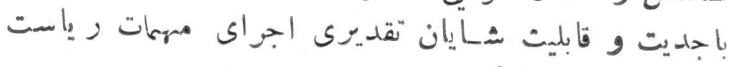

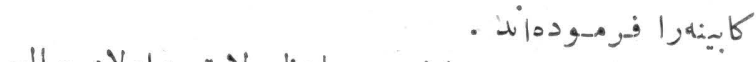

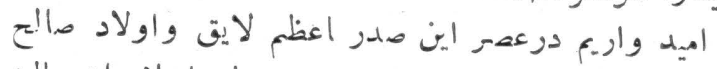

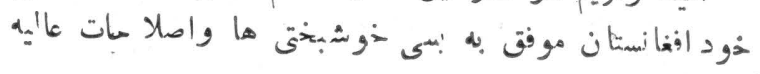
. 20 
صفحة) (1) (

\section{رمزز زرقى}

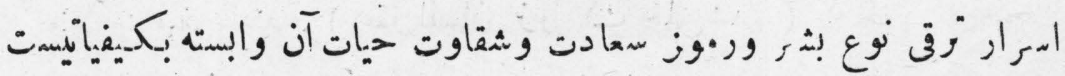

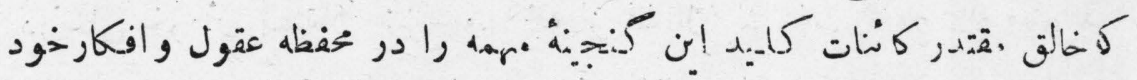

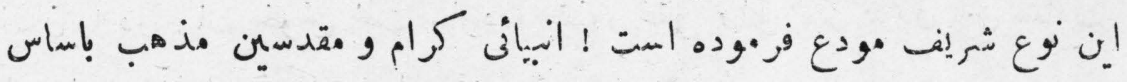

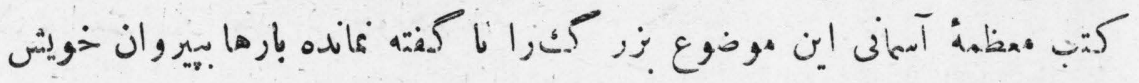

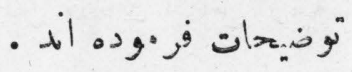

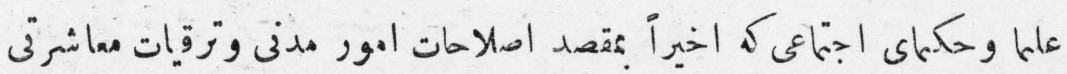

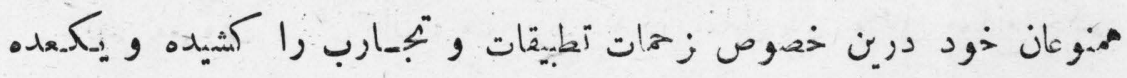

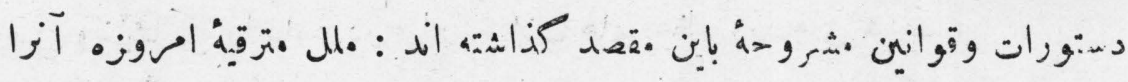

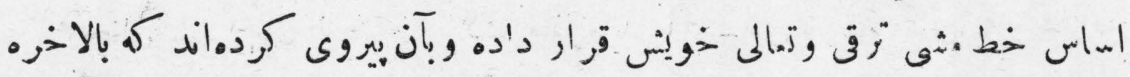

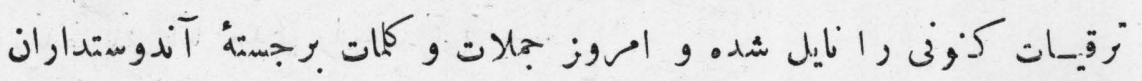

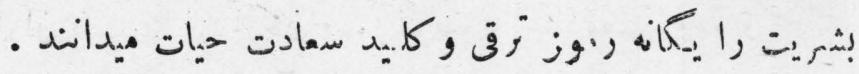

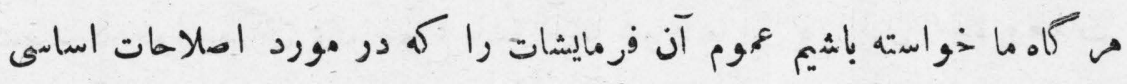

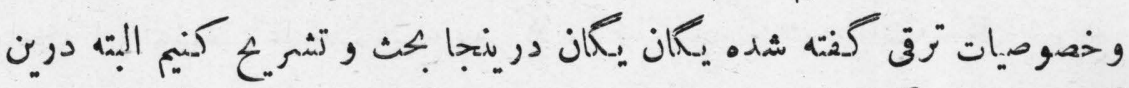

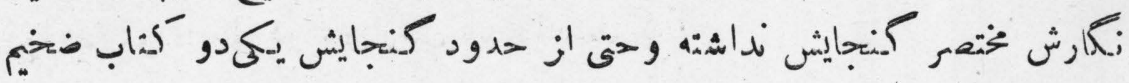

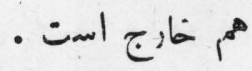

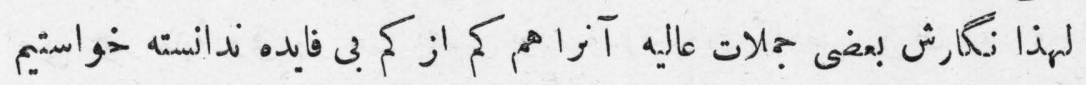

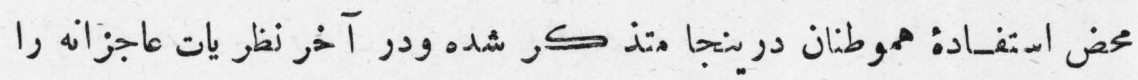
معروضداريم:

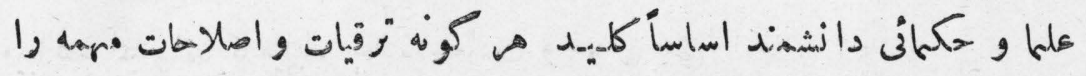




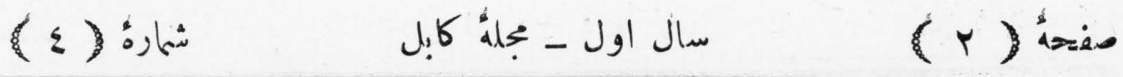

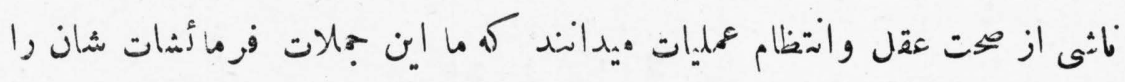

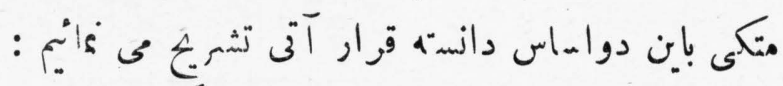

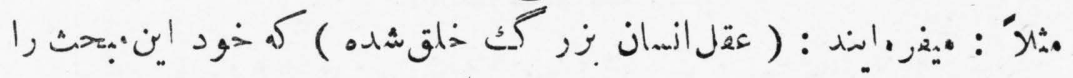

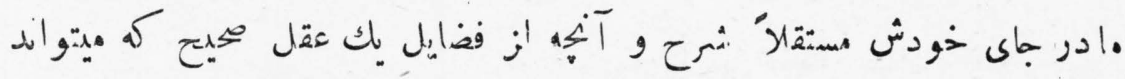

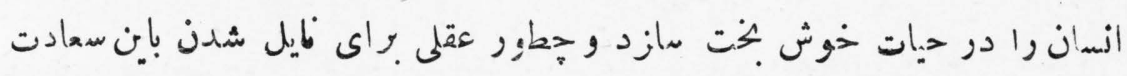

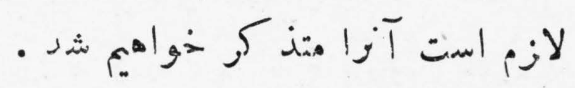

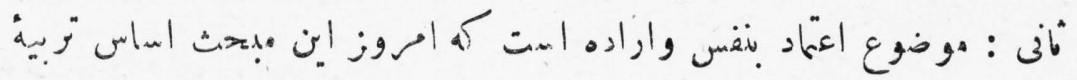

$$
\text { • }
$$

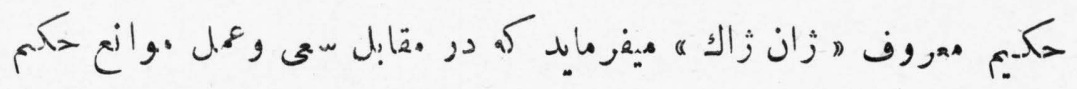

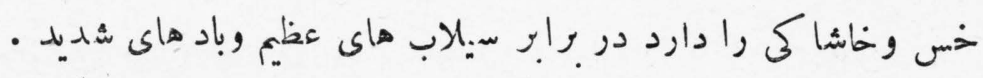

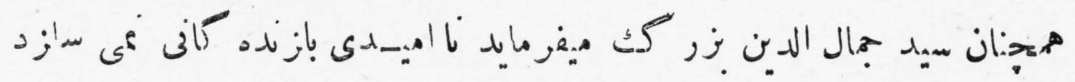

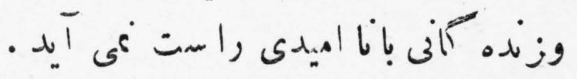

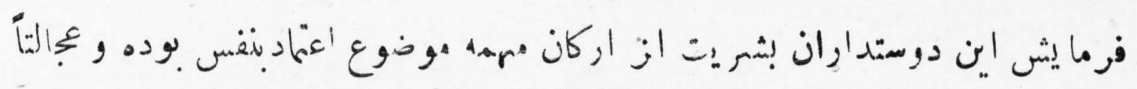

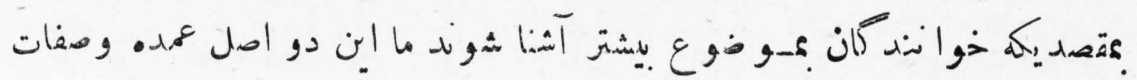

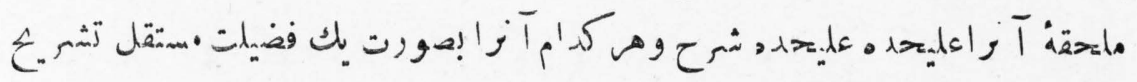

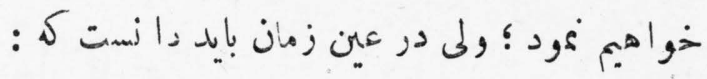

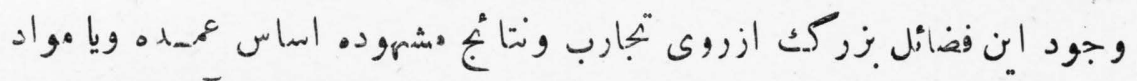

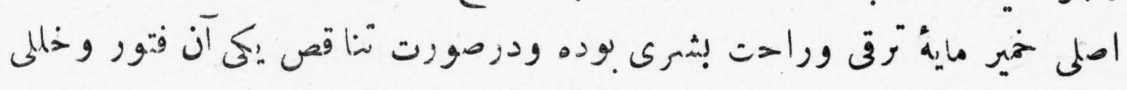

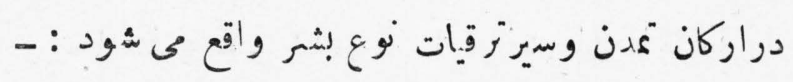

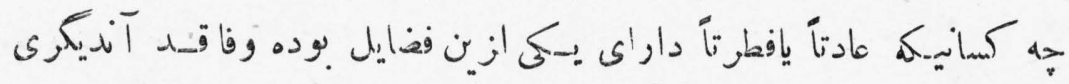

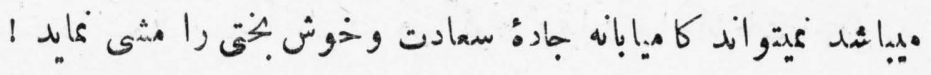




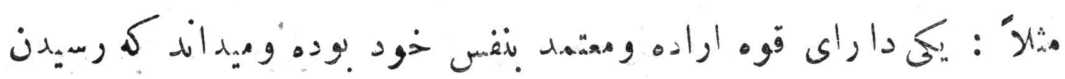

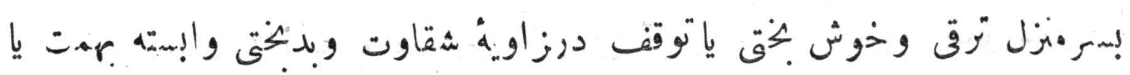

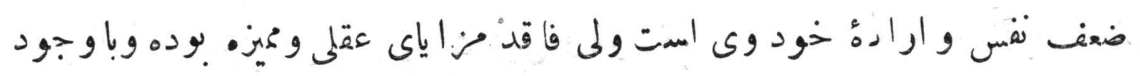

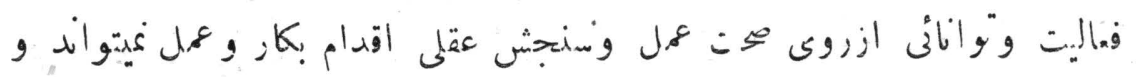

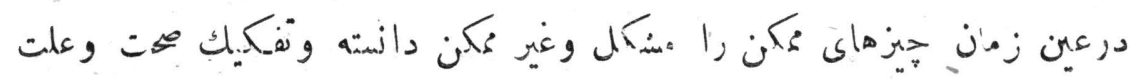

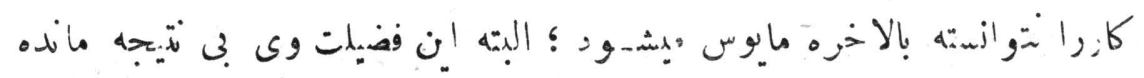

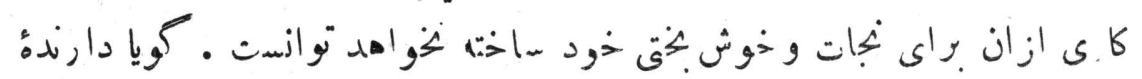

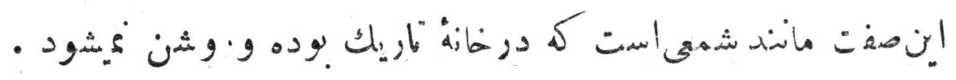

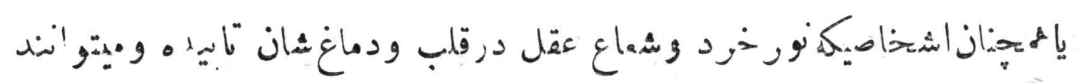

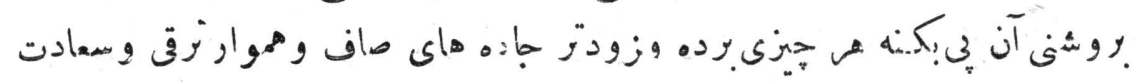

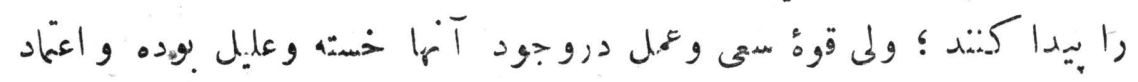

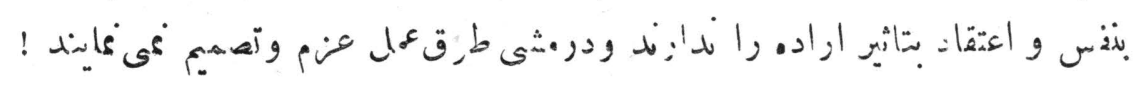

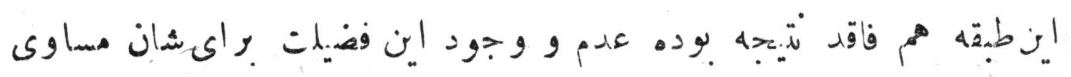

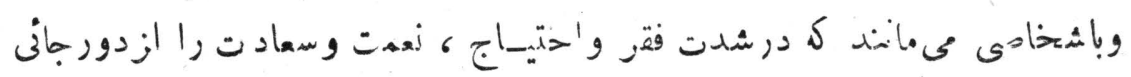

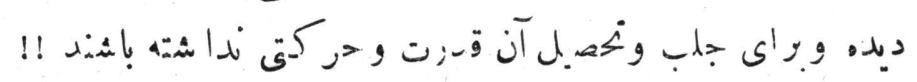

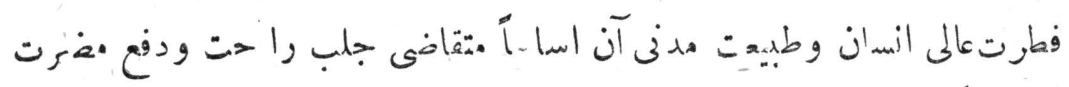

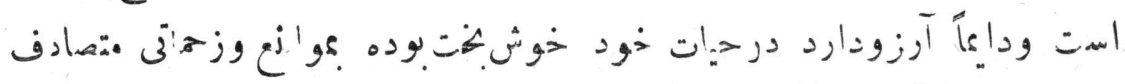

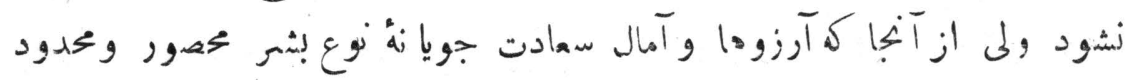

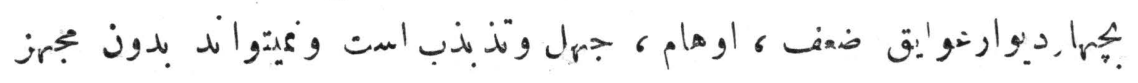

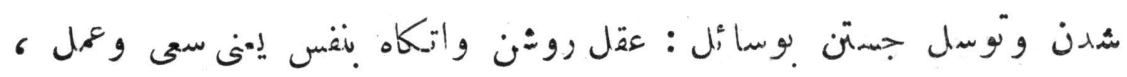

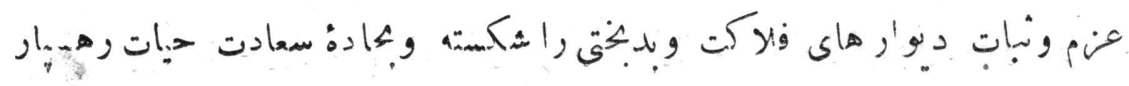


شود البته لازم هينايد ك انسان بايد حصول اين و سايل ثهم را هقدهة نانل

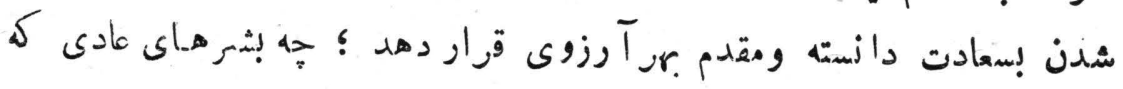

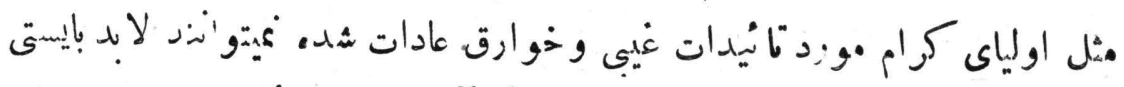

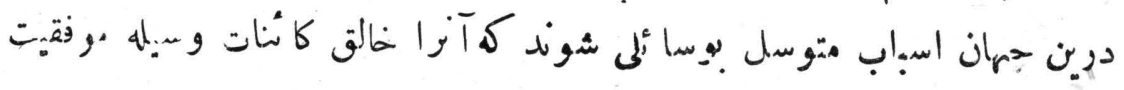

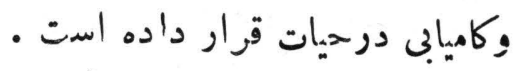

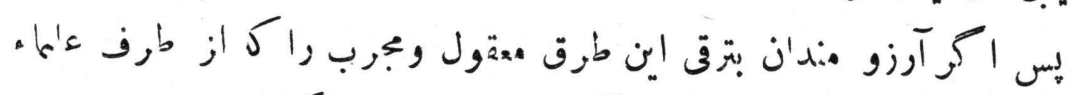

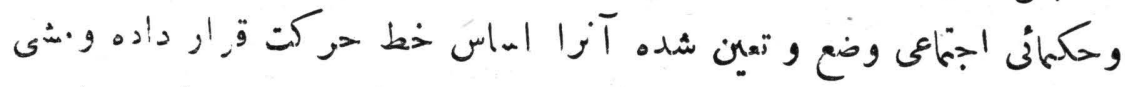

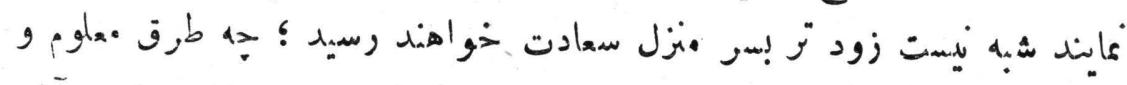

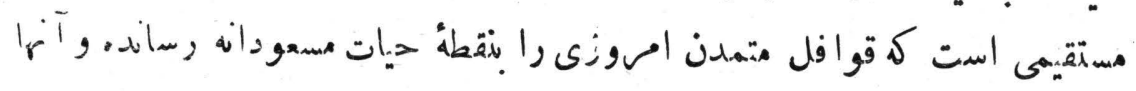

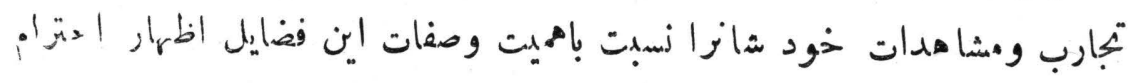
مى نماند

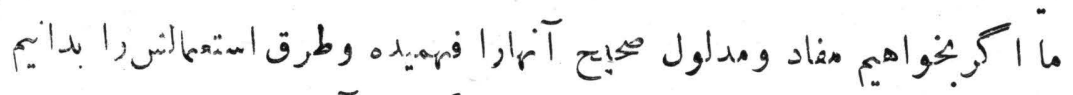

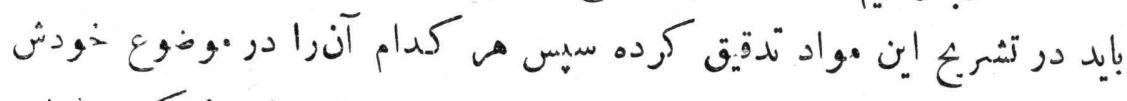

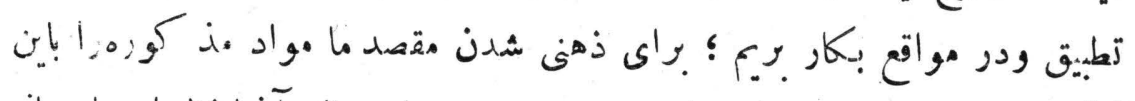

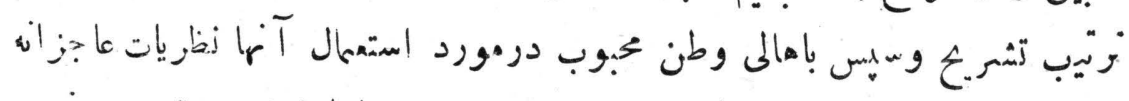

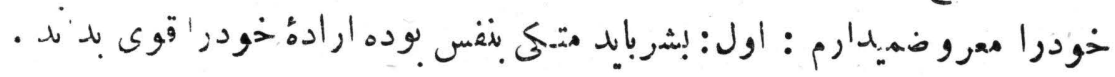

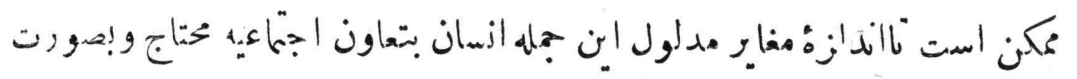

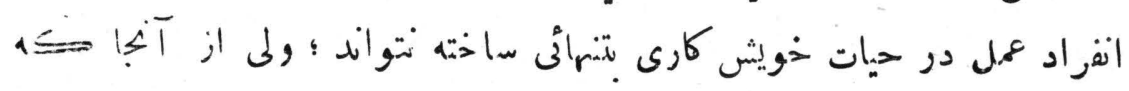

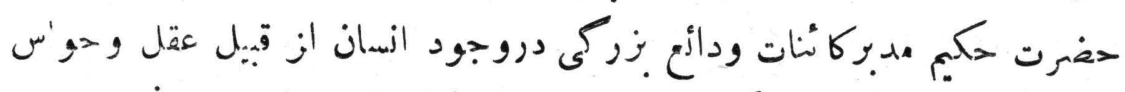

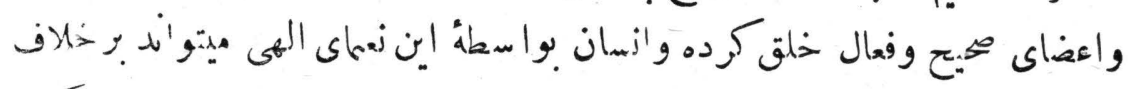

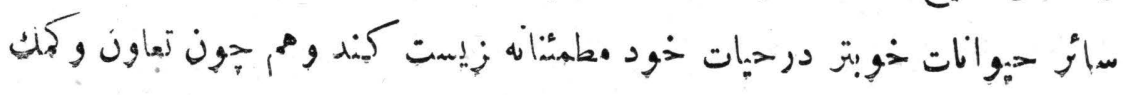




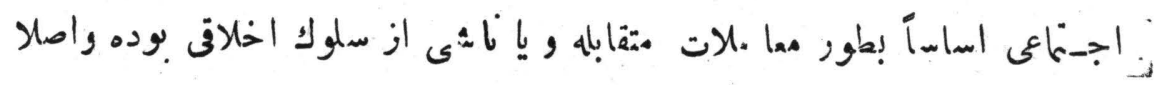

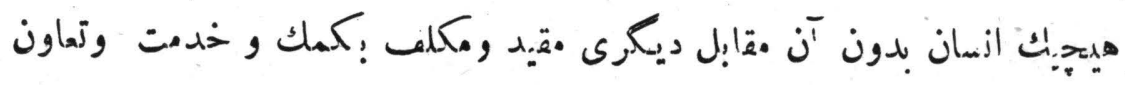

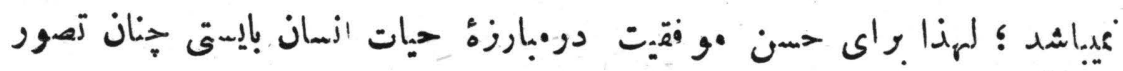

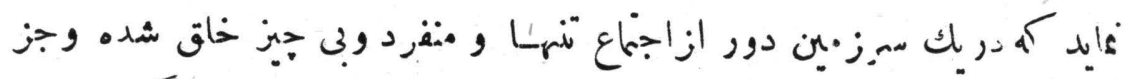

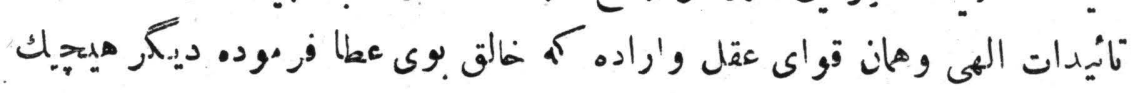

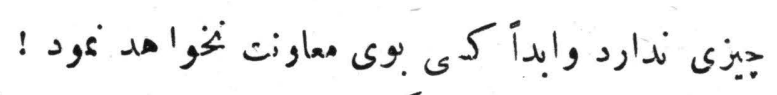

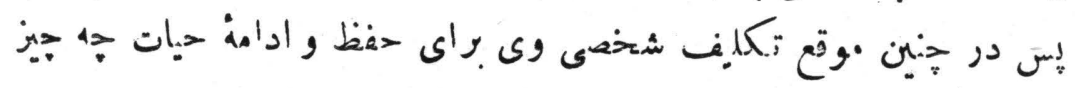

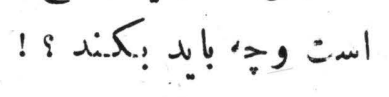

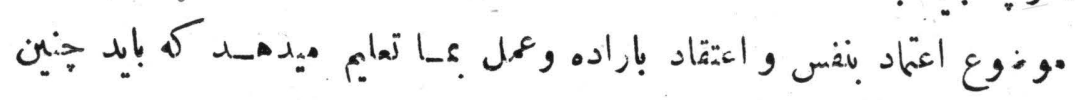

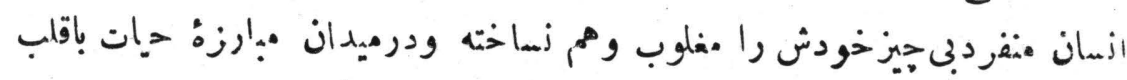

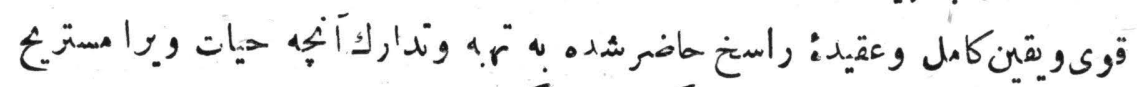

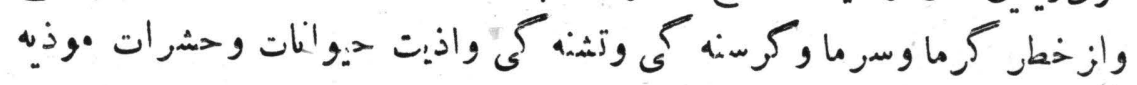

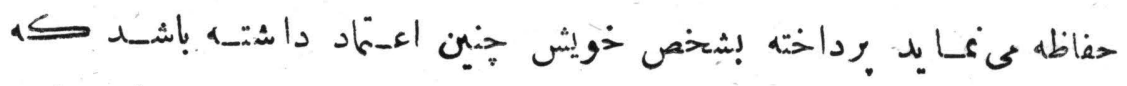

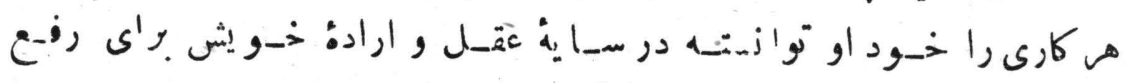

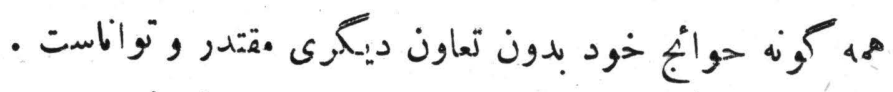

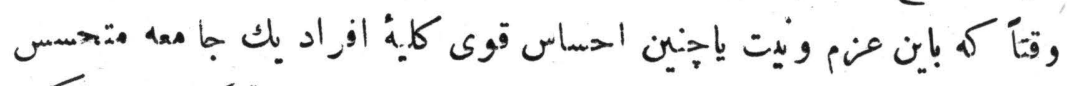

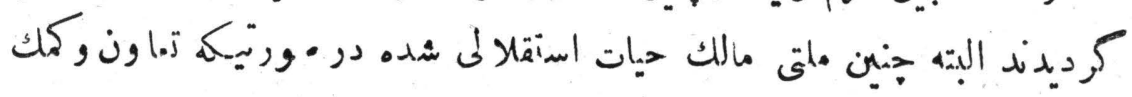

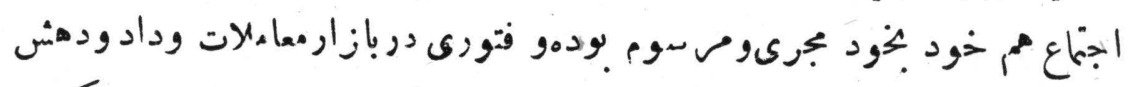

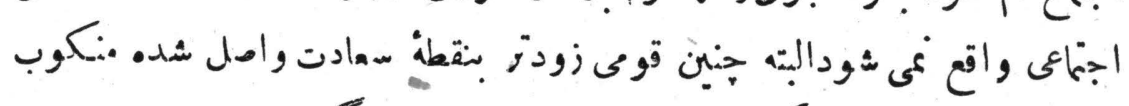

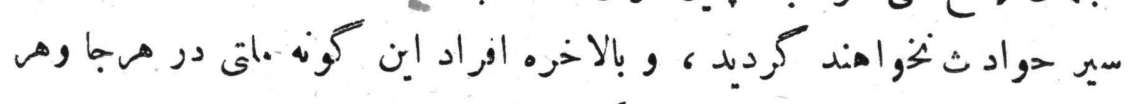

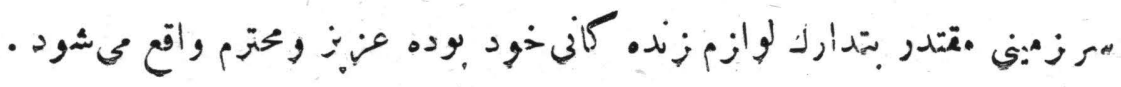


(2)

مسال اول - مجلة كا بل

(1) ixin

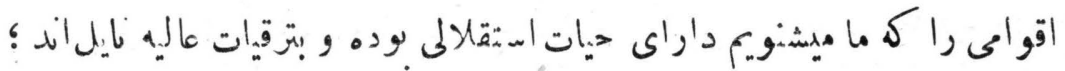

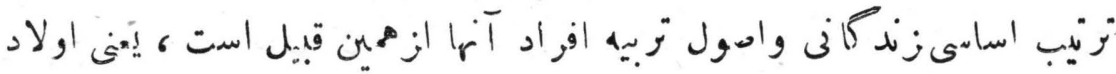

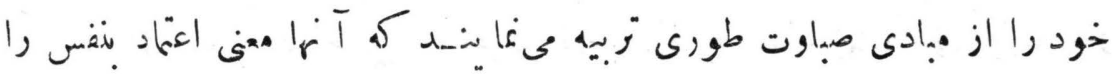

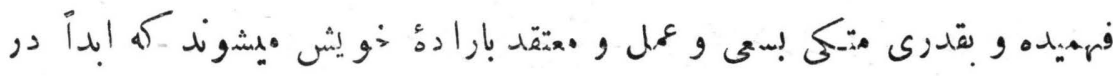

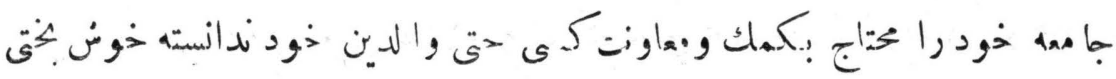

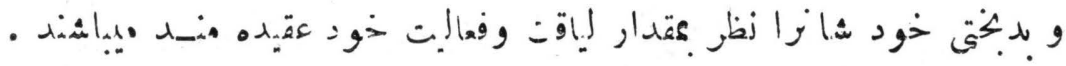

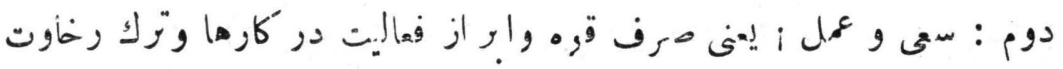

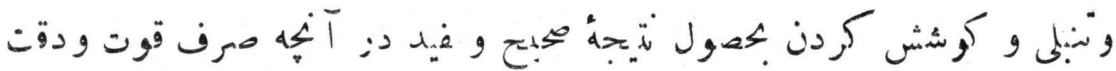

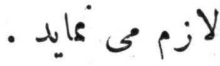

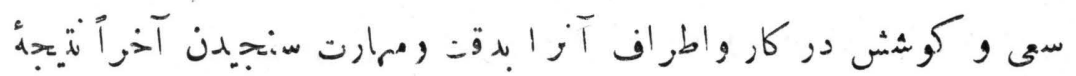

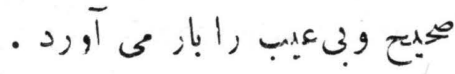

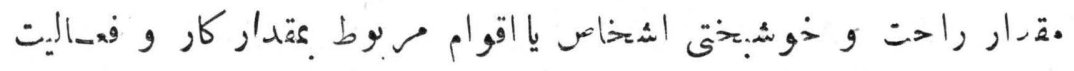

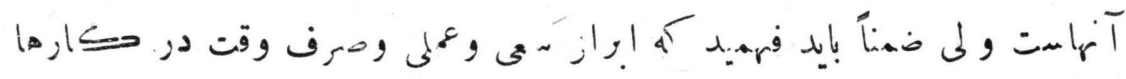

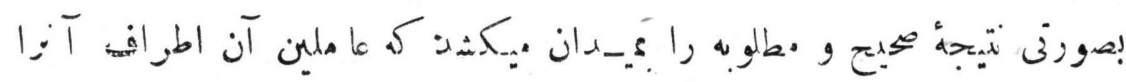

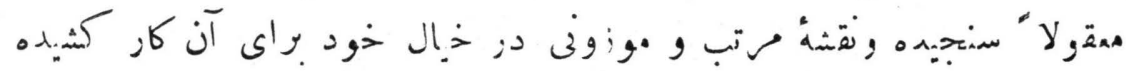

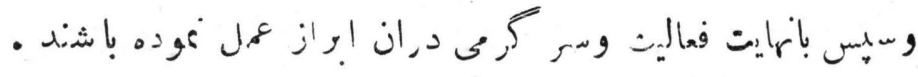

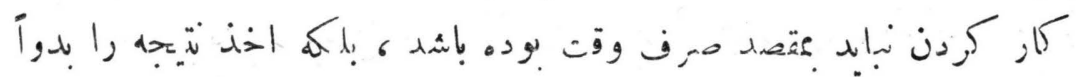

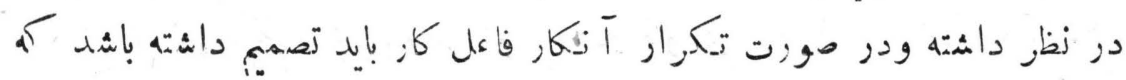

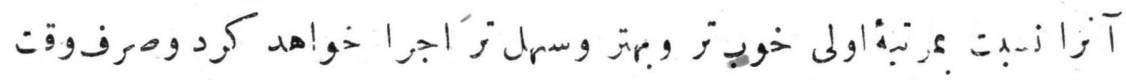

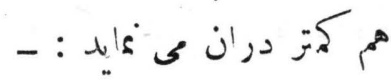

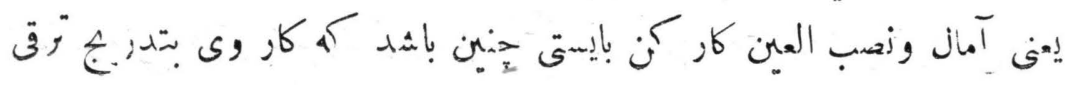


(2) شال أول -

(v) area

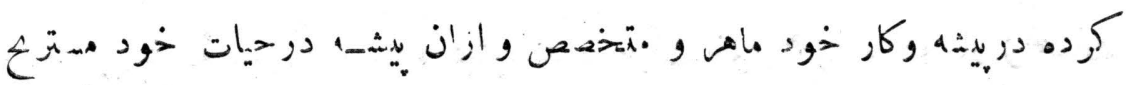

واقع شود . نره دون

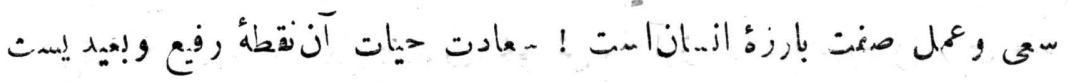

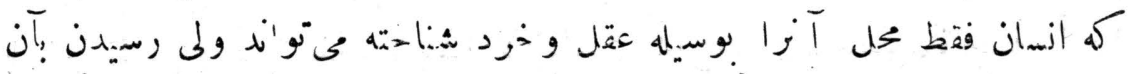

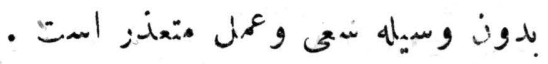

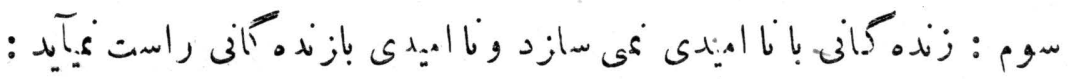

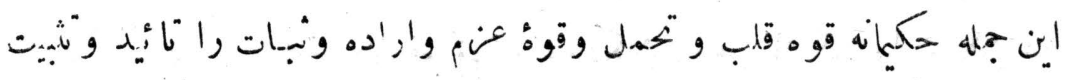

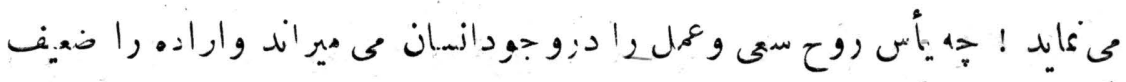

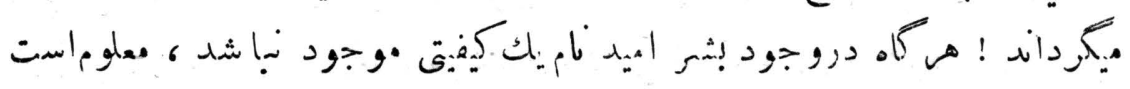

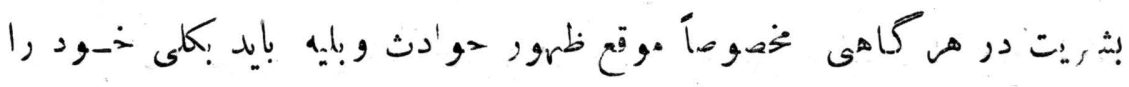

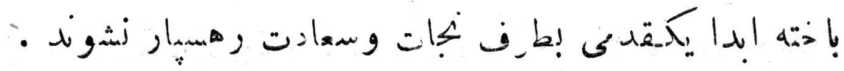

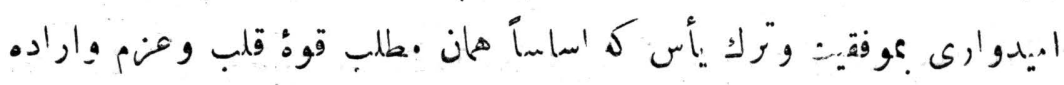

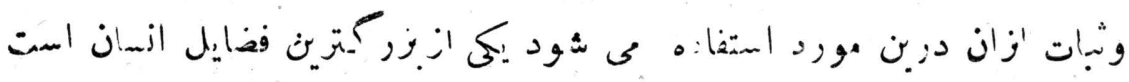

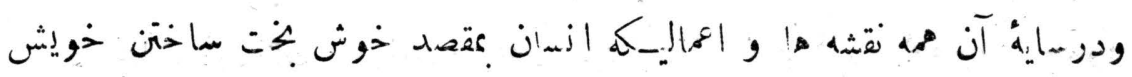

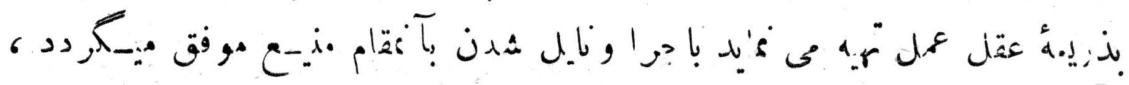

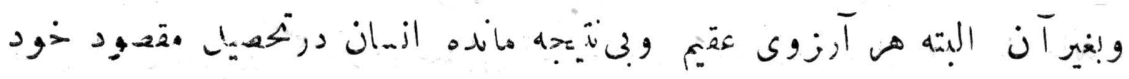

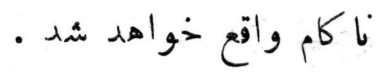

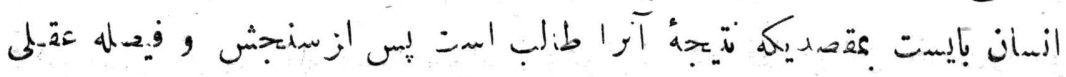

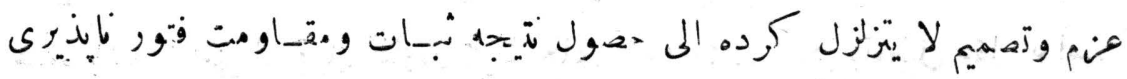

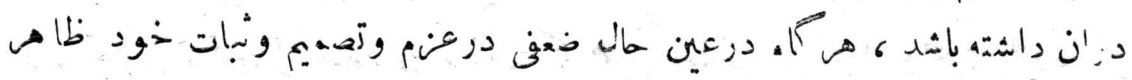

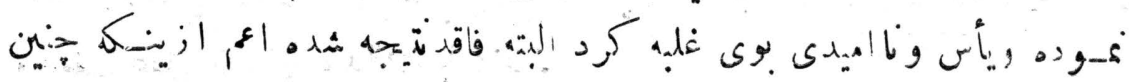




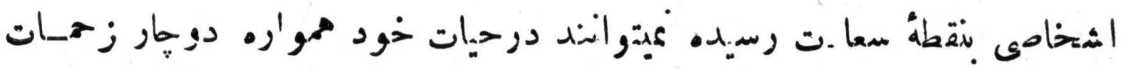

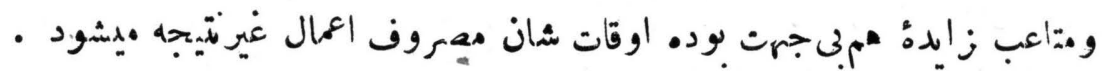

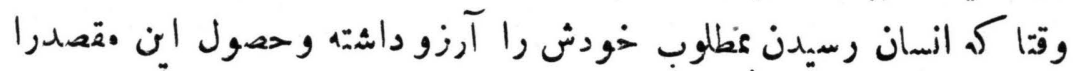

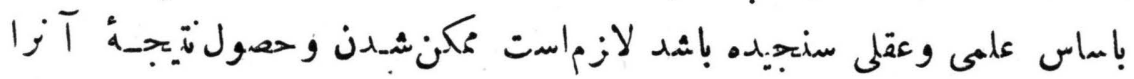

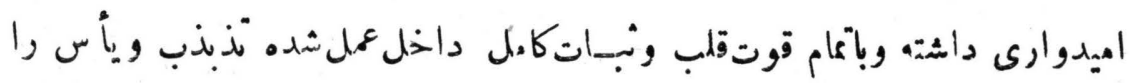
- درخاطر راه ندهد

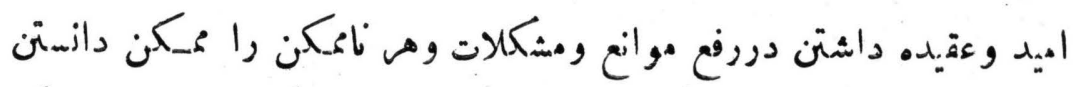

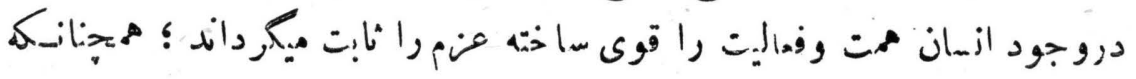

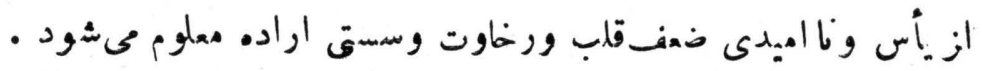

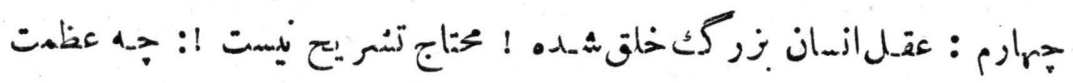

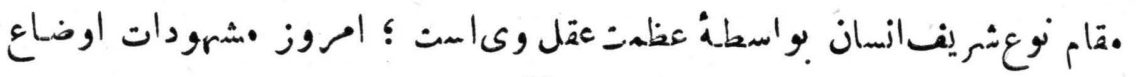

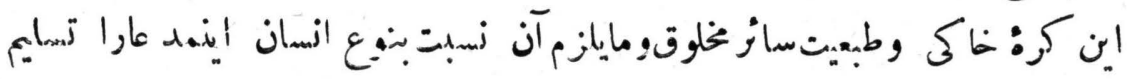

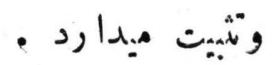

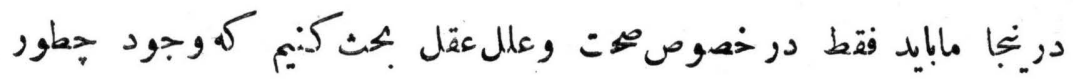

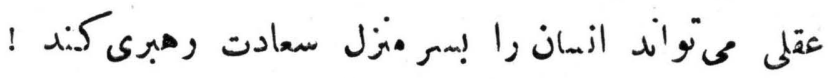

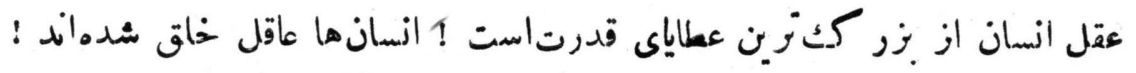

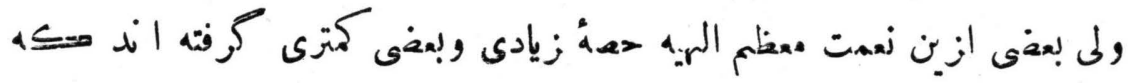

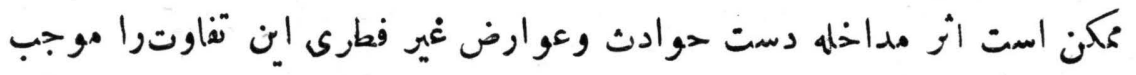

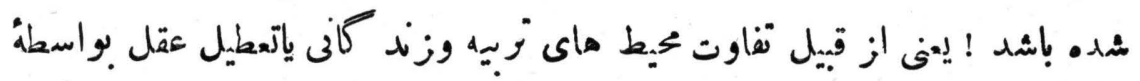

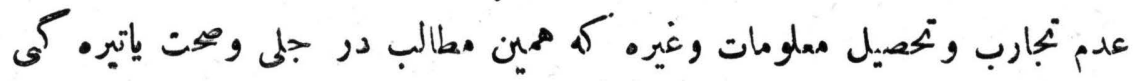

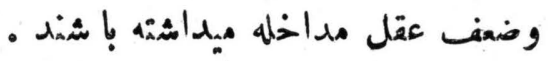




\section{سال اول - مجله كابل}

هروحال وقتا كه ما همترف شيديم كم هـ انسان فطرتاً عاقل است ودر سايه.

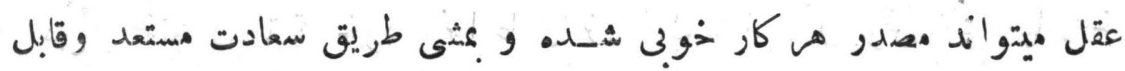

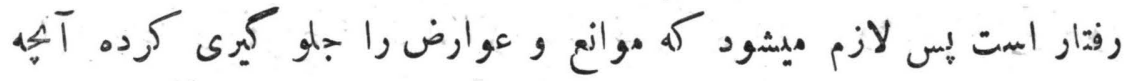

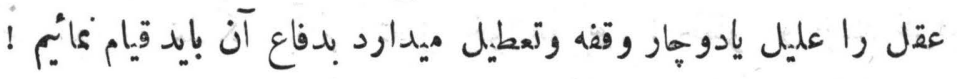

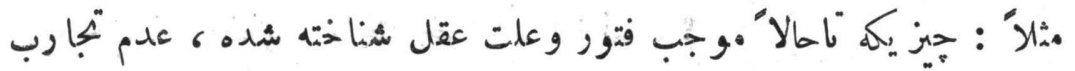

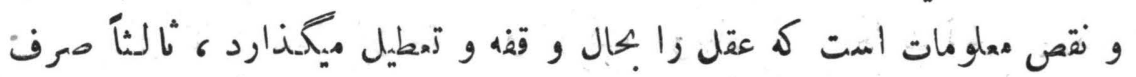

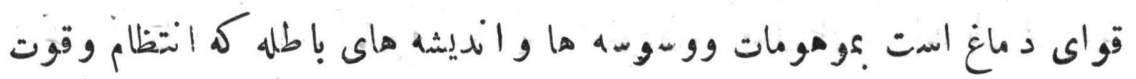

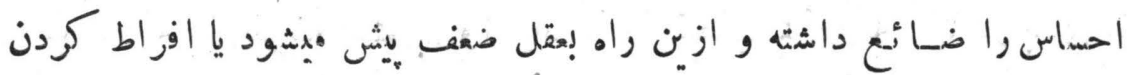

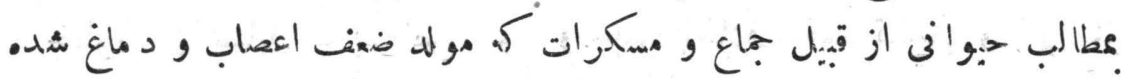

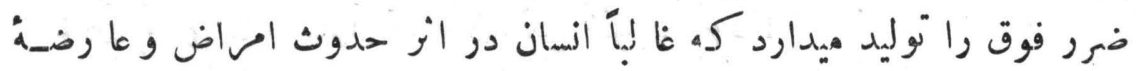

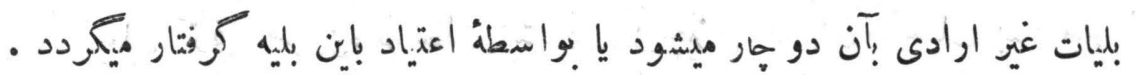

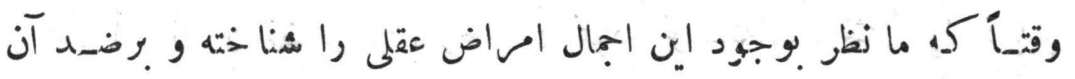

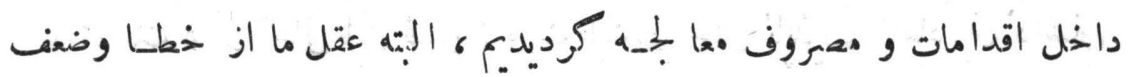

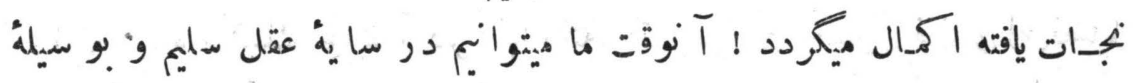

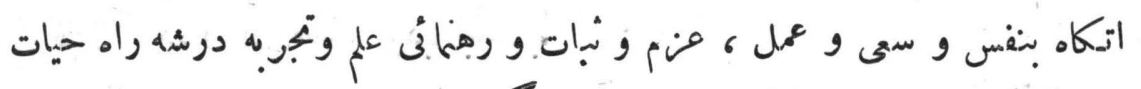

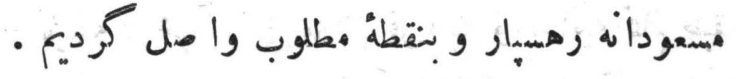

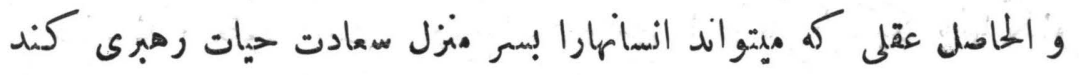

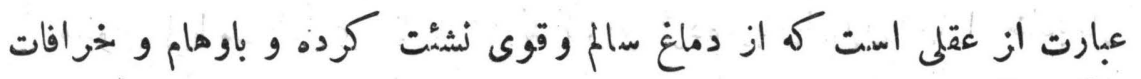

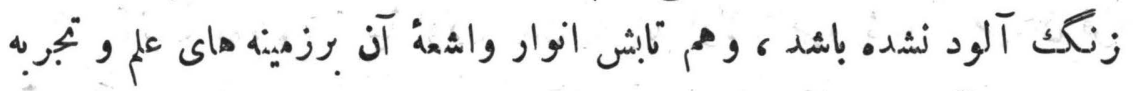

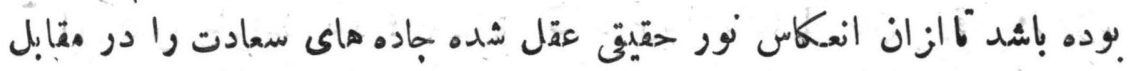

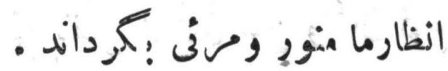




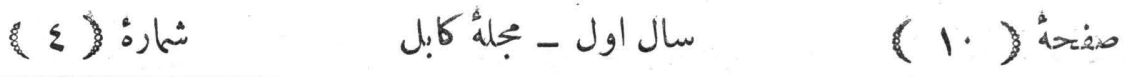

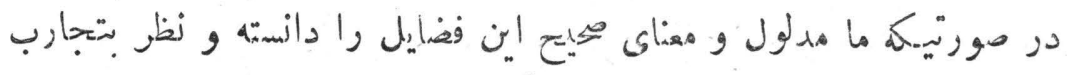

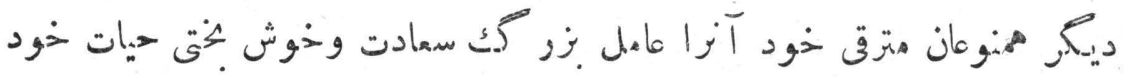

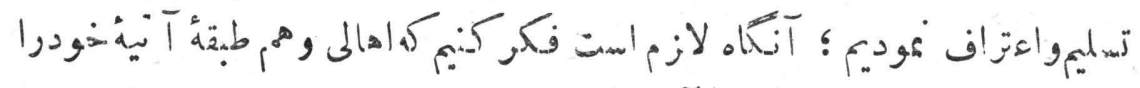

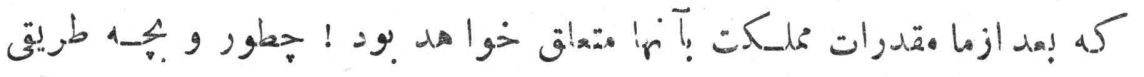

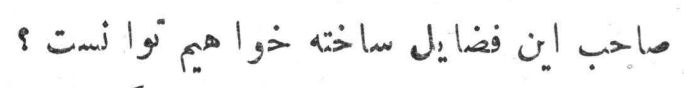

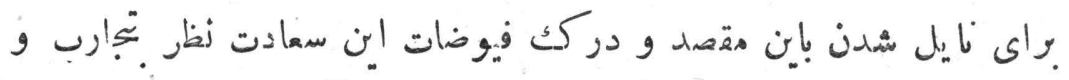

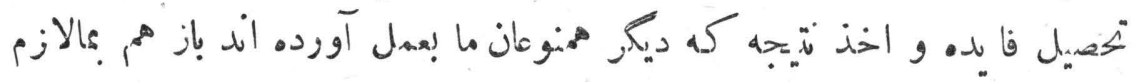

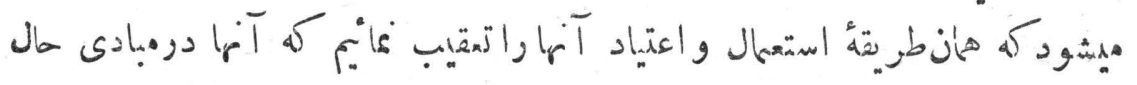

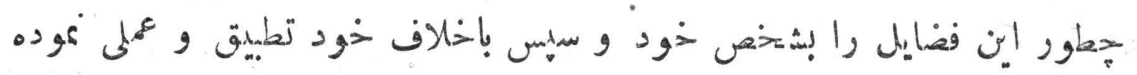

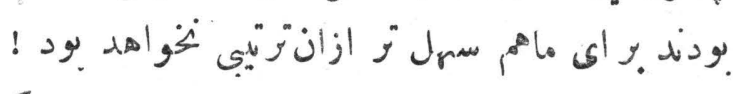

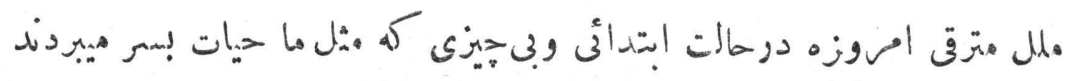

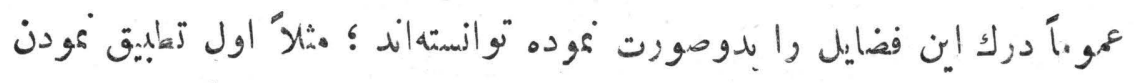

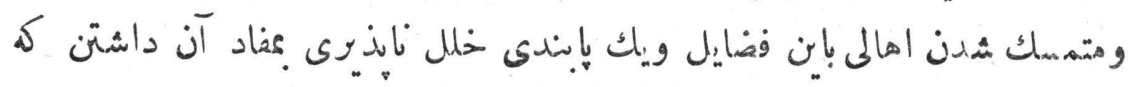

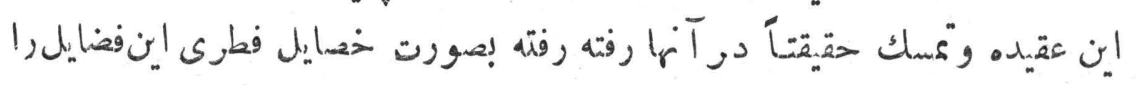

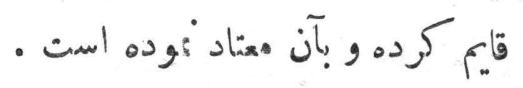

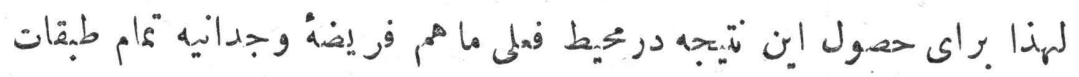

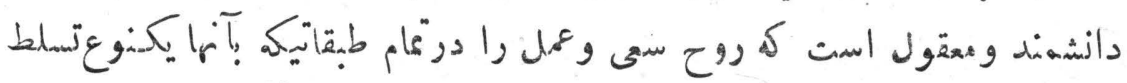

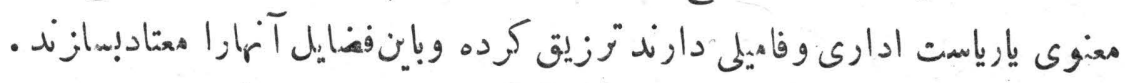

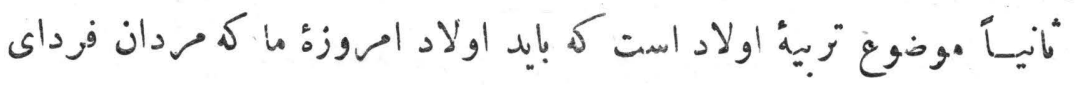

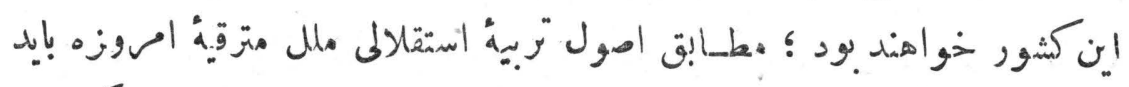

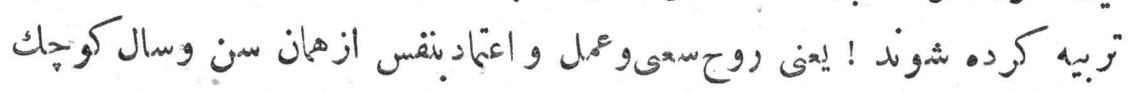




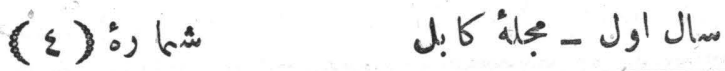

درانها جلومكرشده عقل شان بمرض كرفنتارنشود.

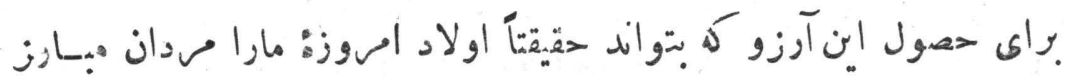

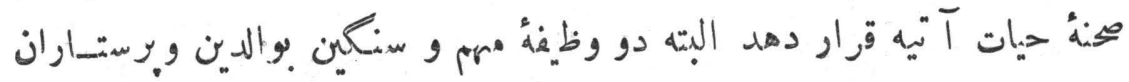

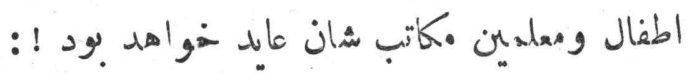

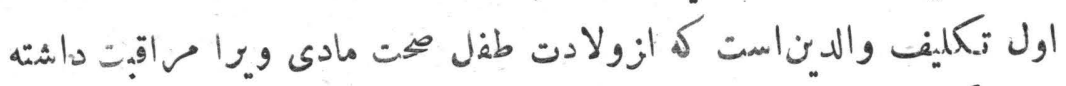

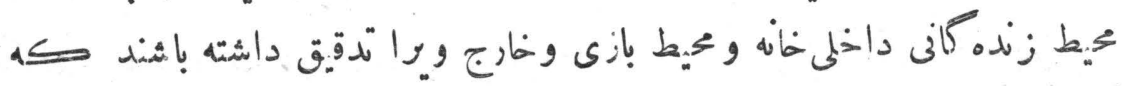

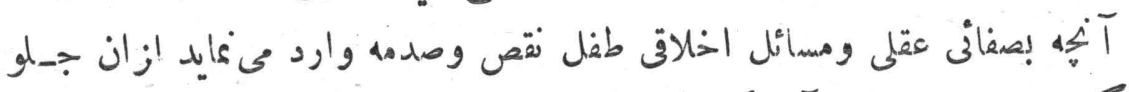

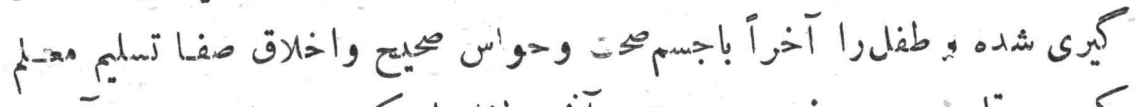

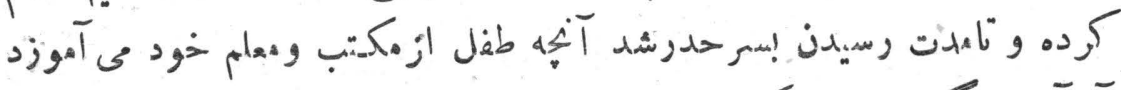

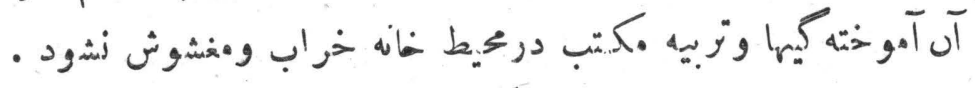

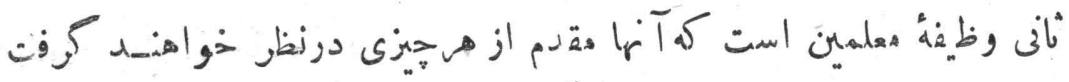

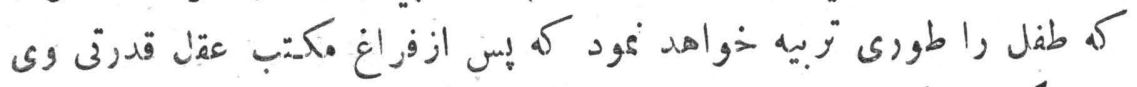

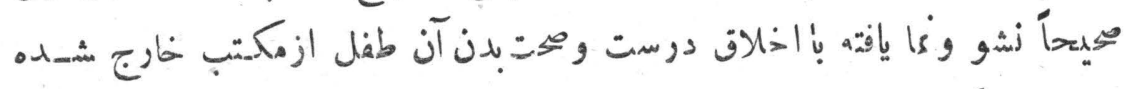

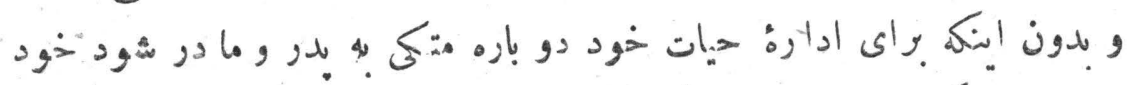

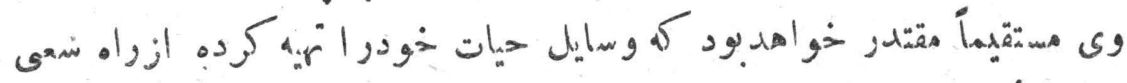

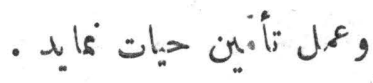

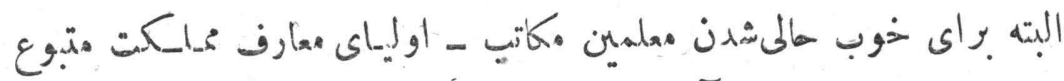

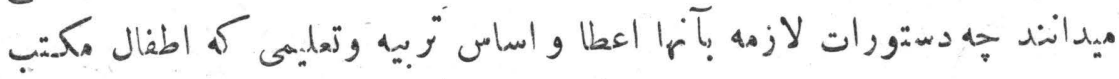

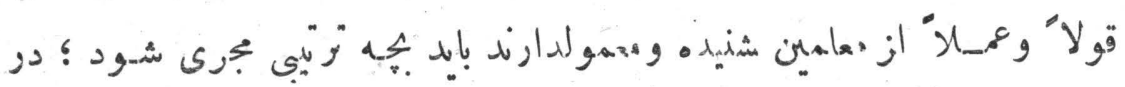

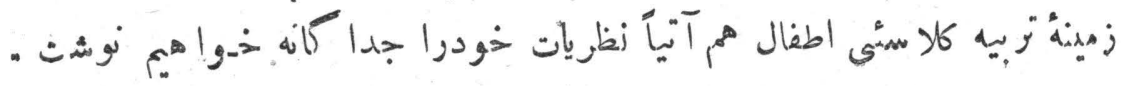

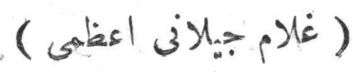




\section{مبرزا عبد القادر بيدل}

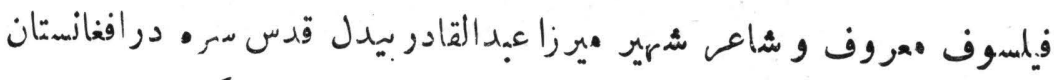

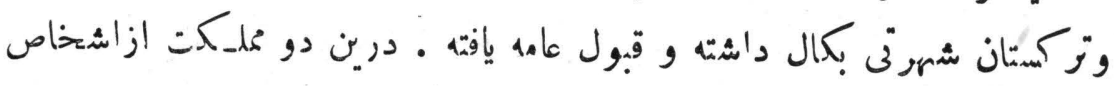

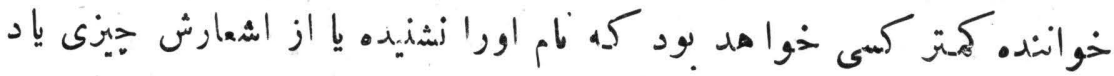

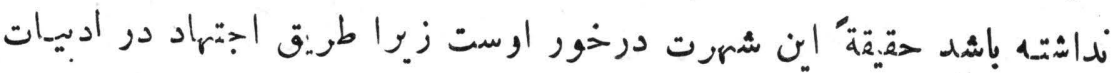

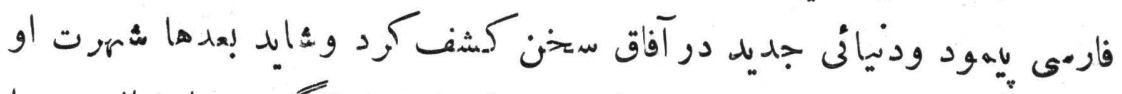

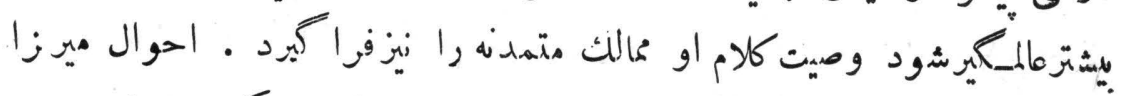

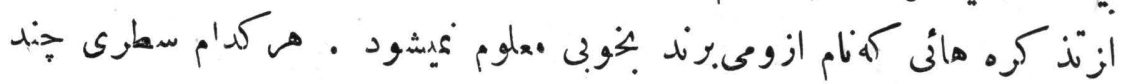

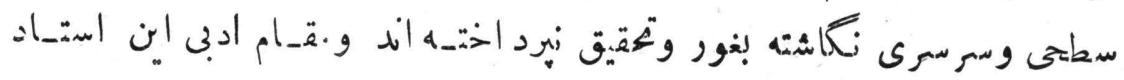

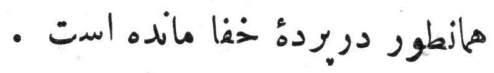

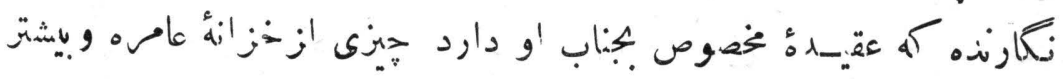

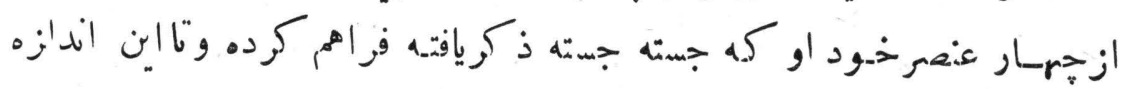

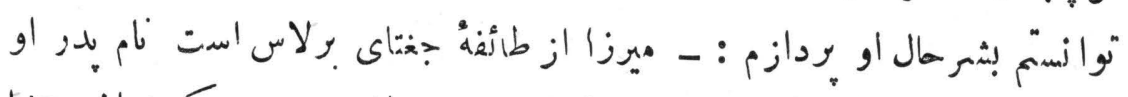

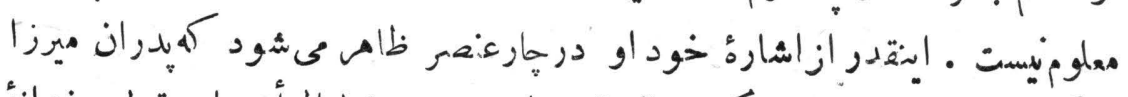

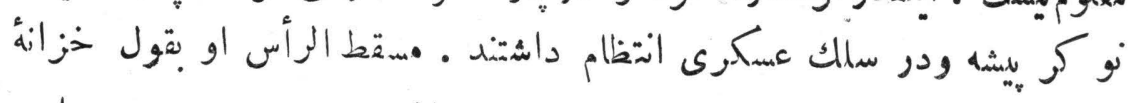

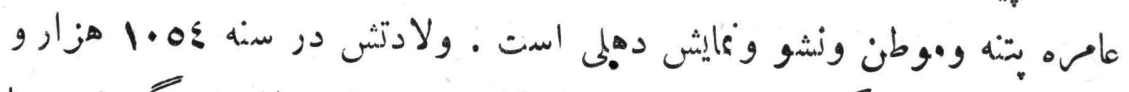

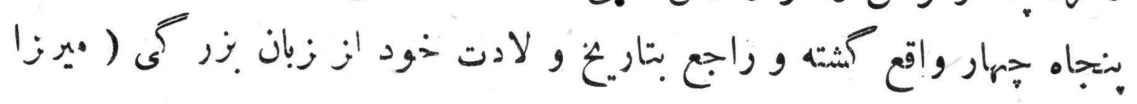

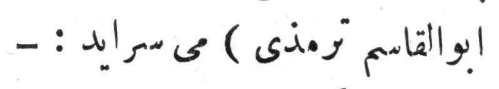

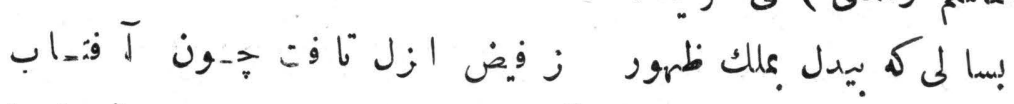

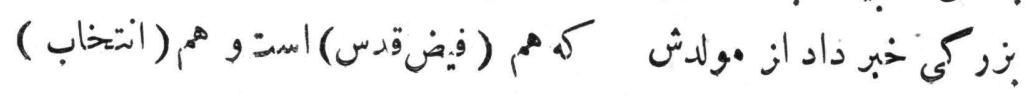




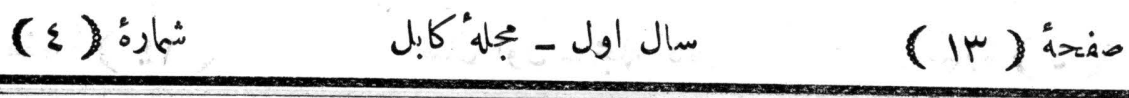

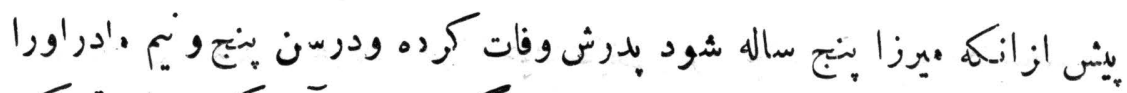

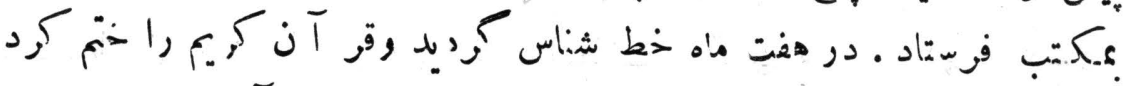

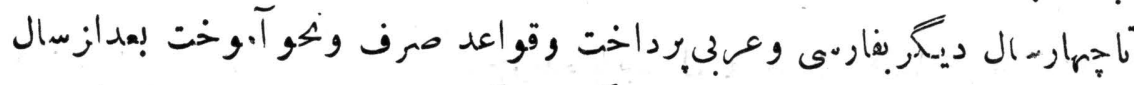

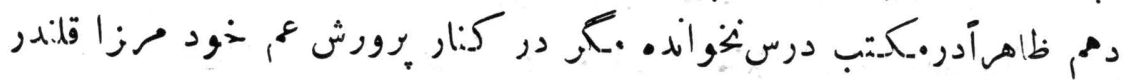

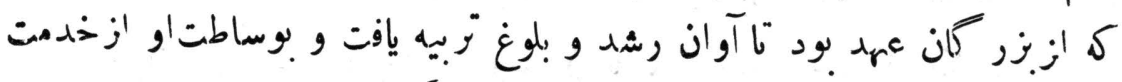

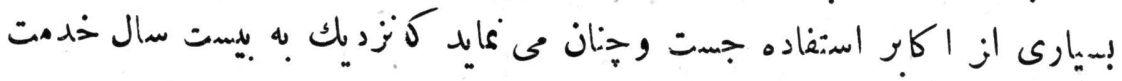

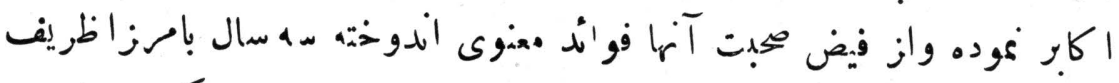

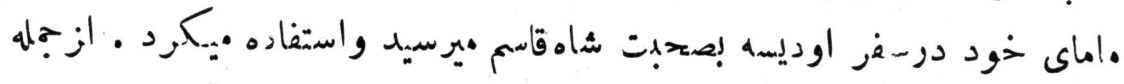

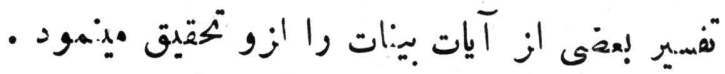

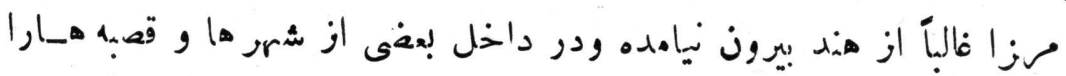

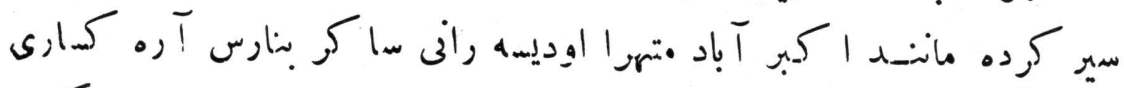

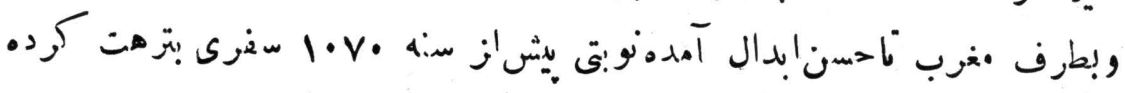

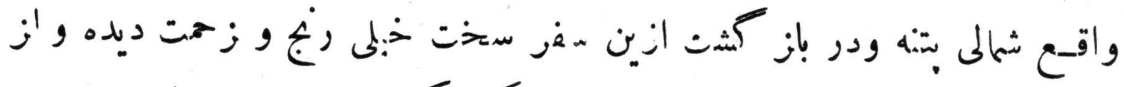

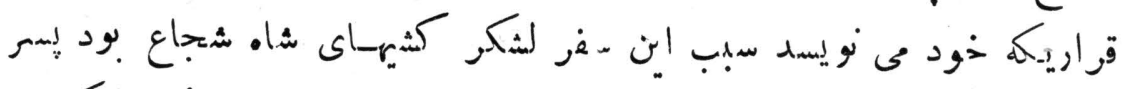

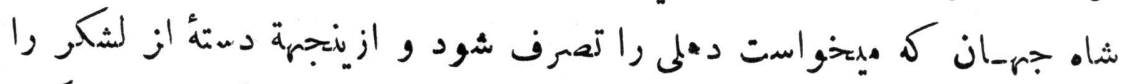

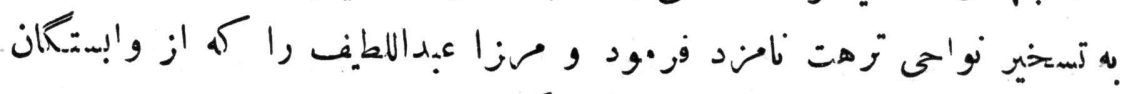

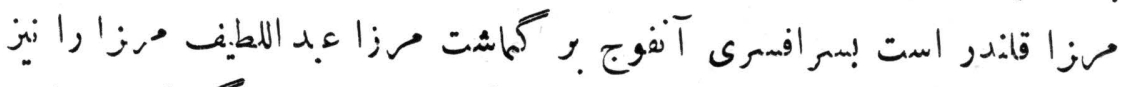

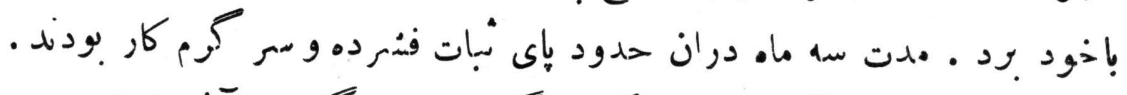

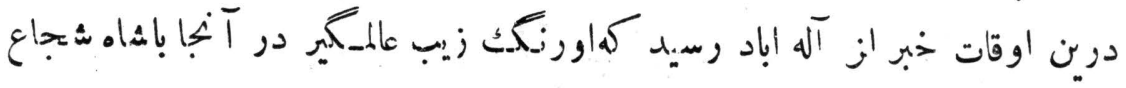

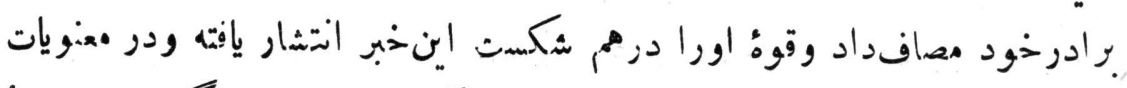

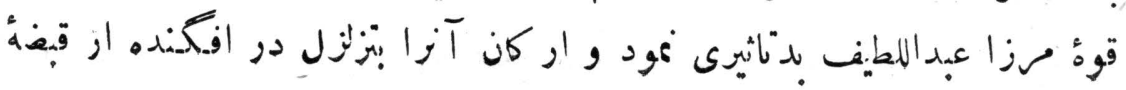




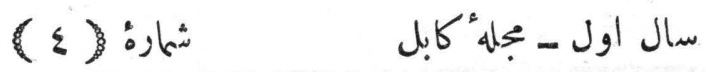

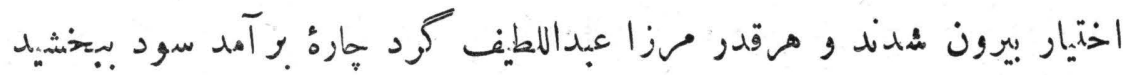

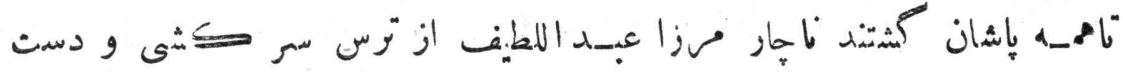

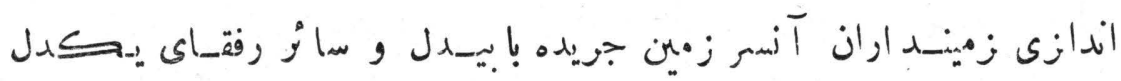

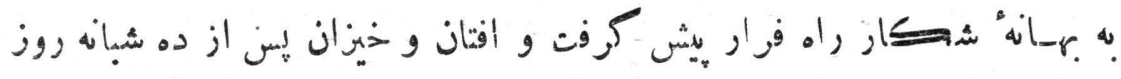

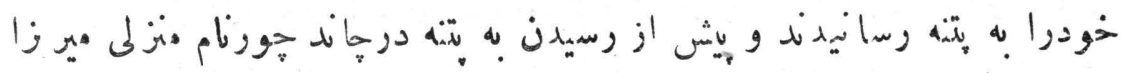

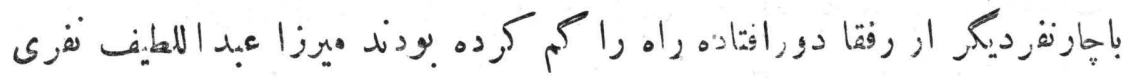

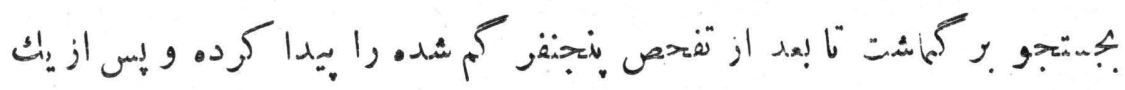

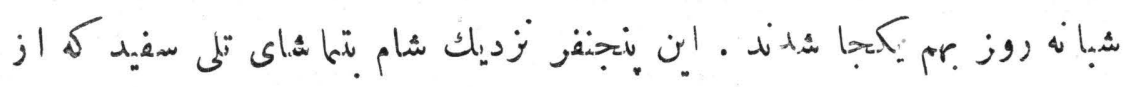

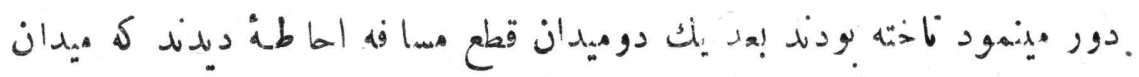

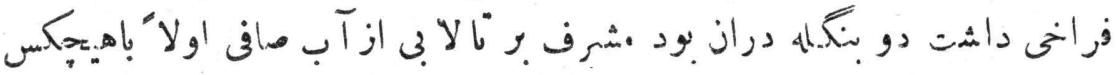

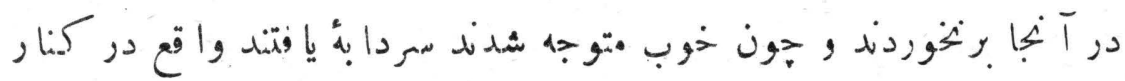

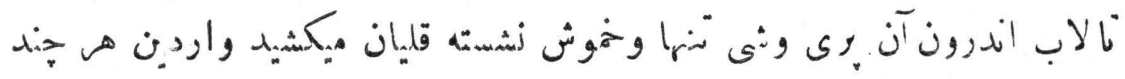

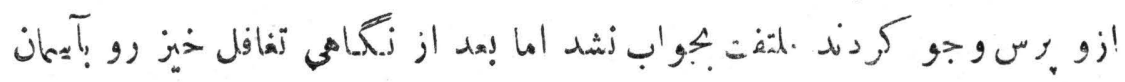

$$
\text { كر }
$$

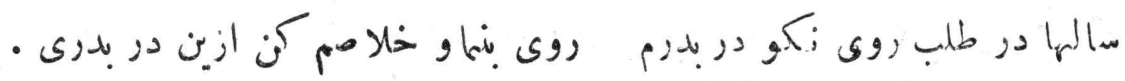

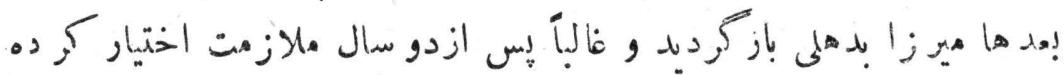

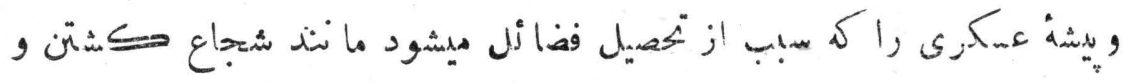

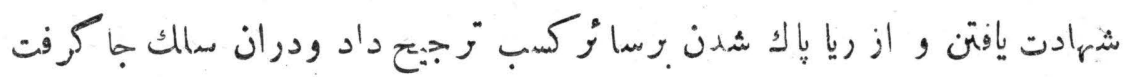

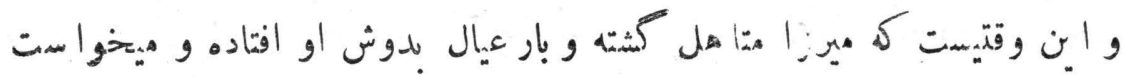

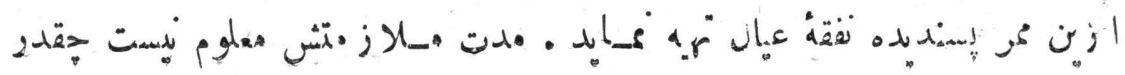




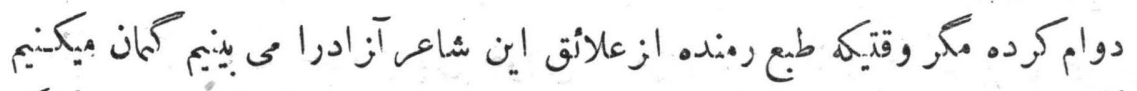

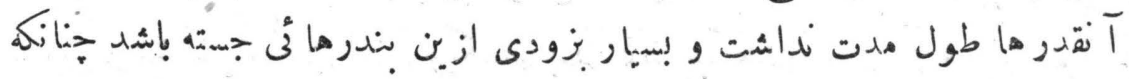

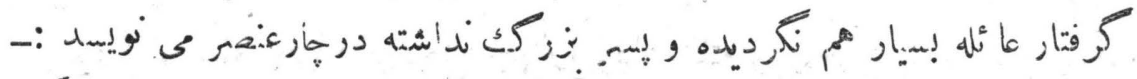

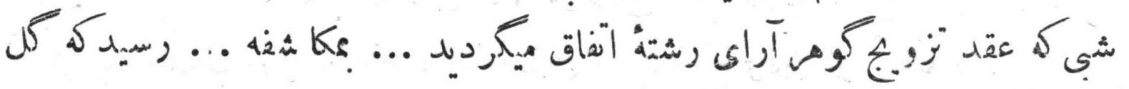

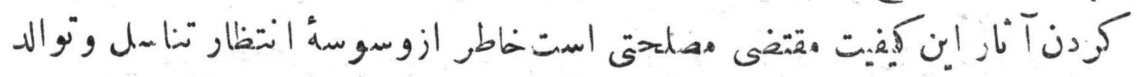

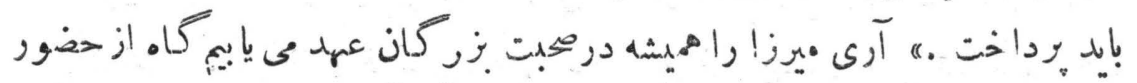

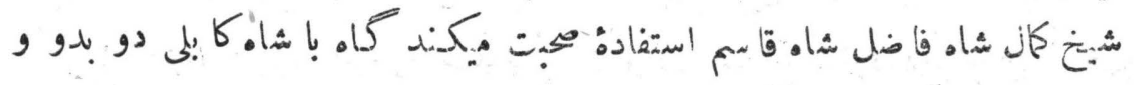

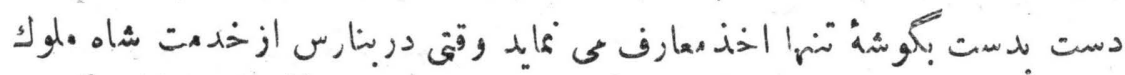

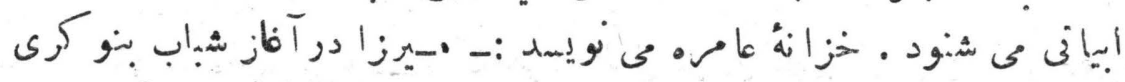

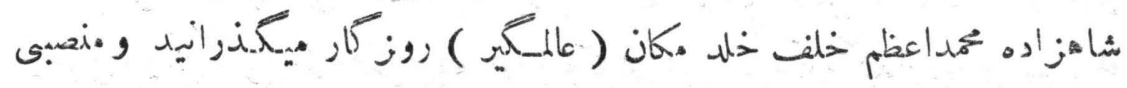

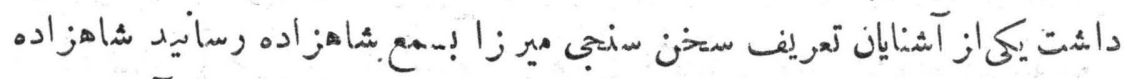

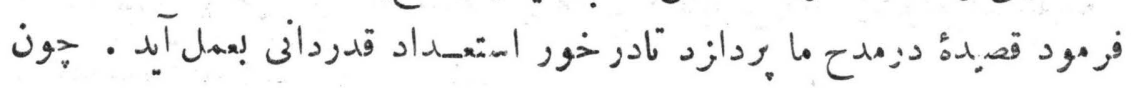

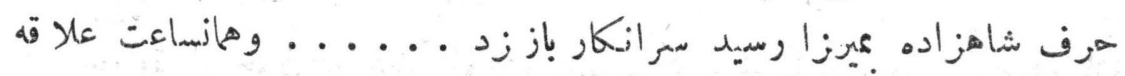

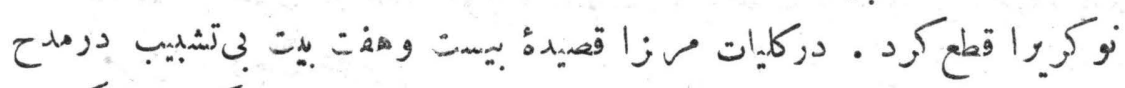

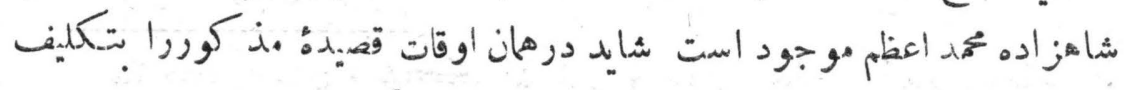

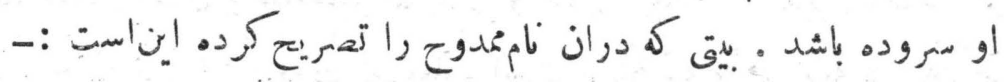

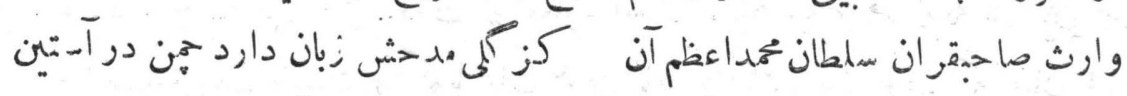

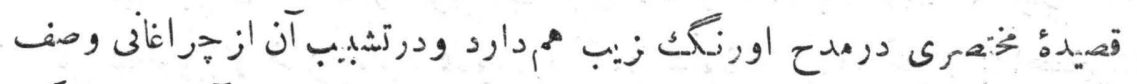

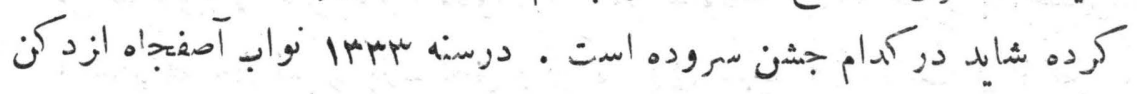

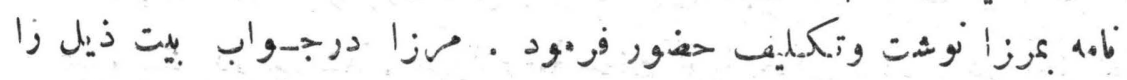

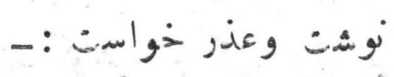


(s): ش

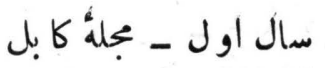

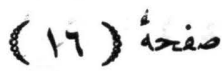

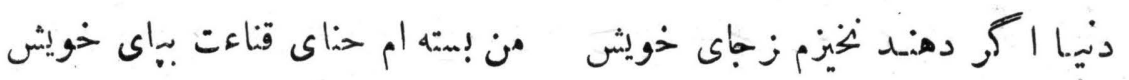

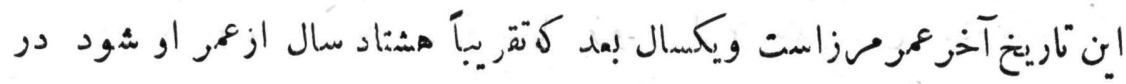

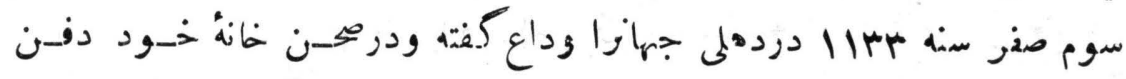

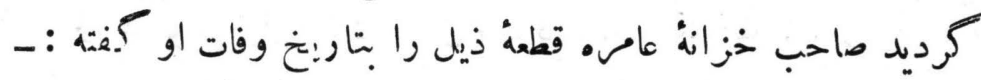

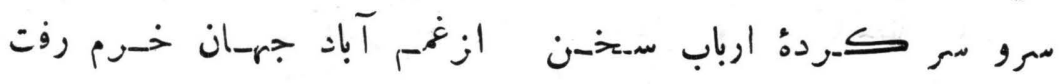

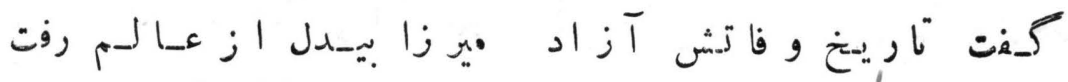

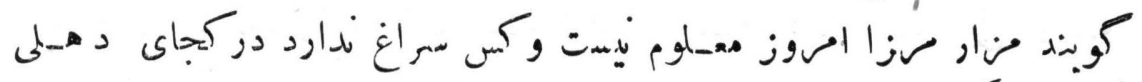

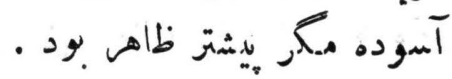

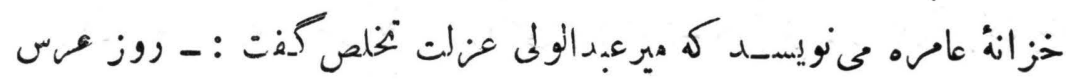

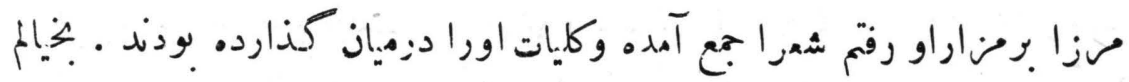

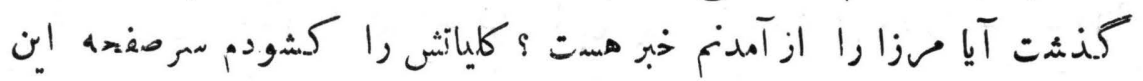

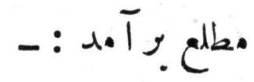

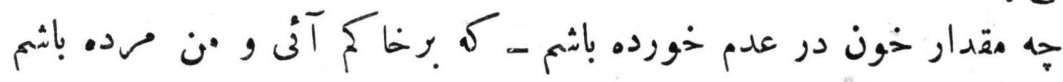

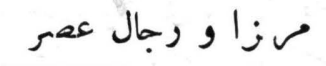

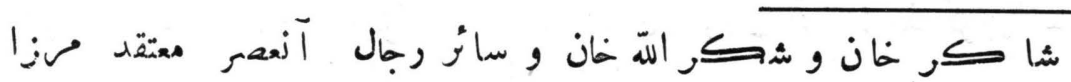

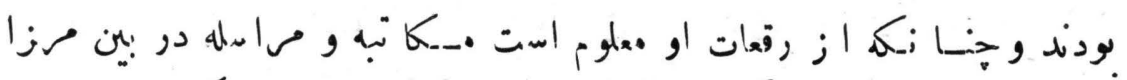

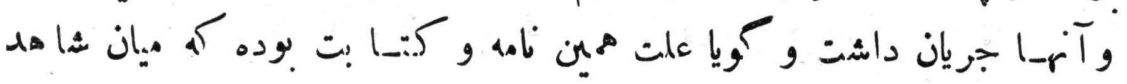

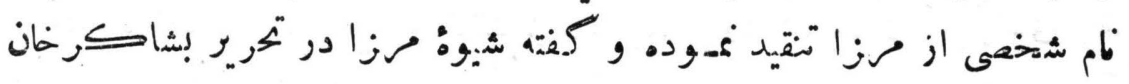

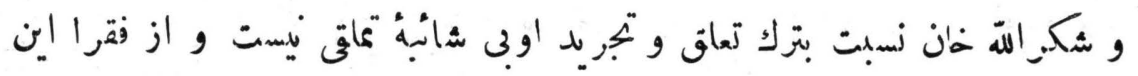

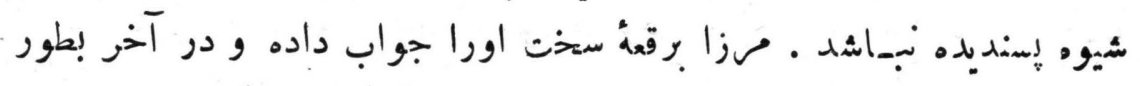

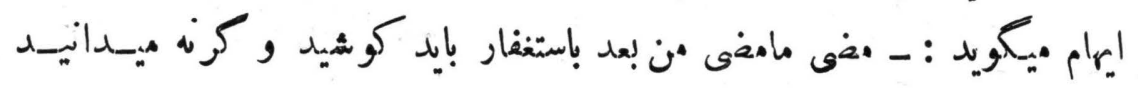


(c)

سال أول - مجله كابل

(IV) (20)

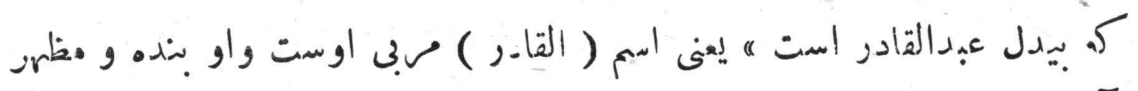

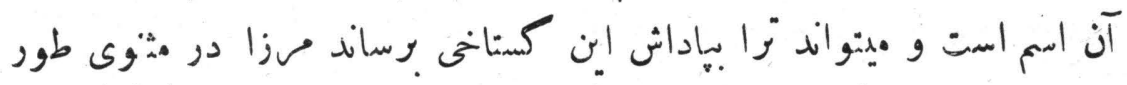

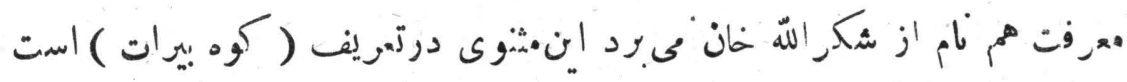

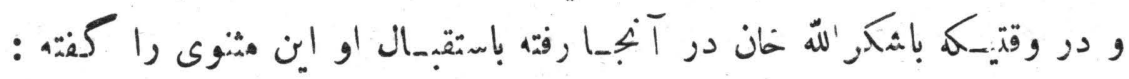

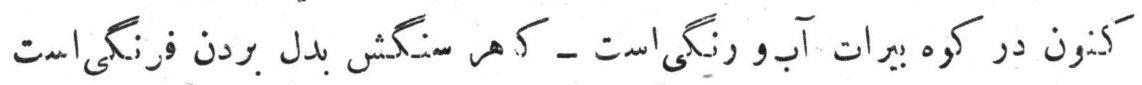

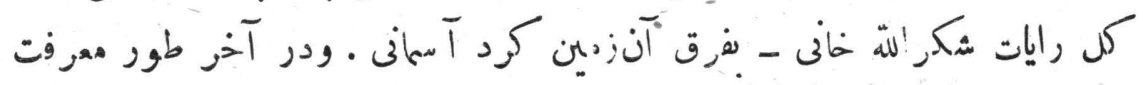

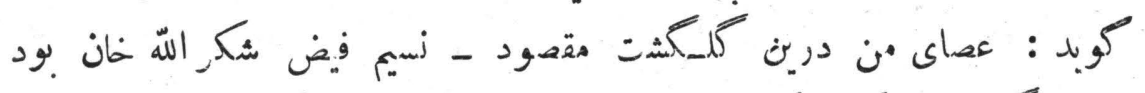

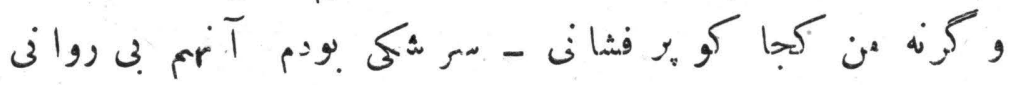

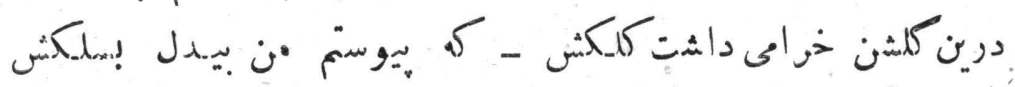

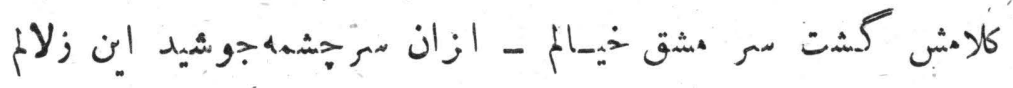

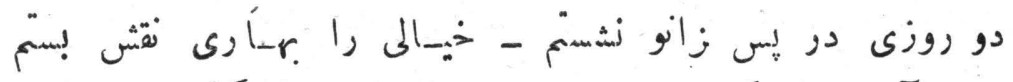

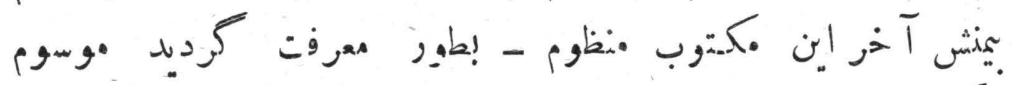

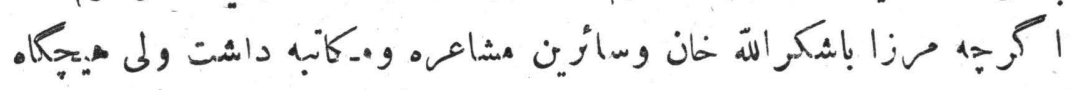

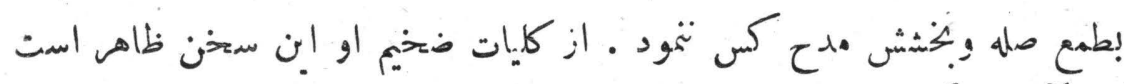

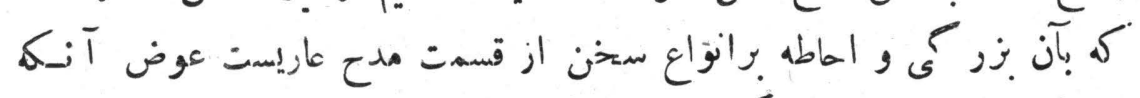

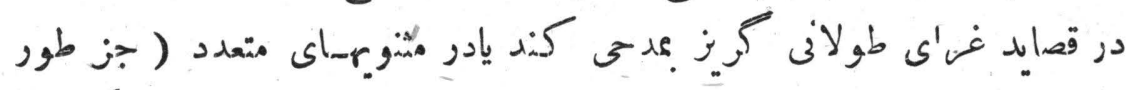

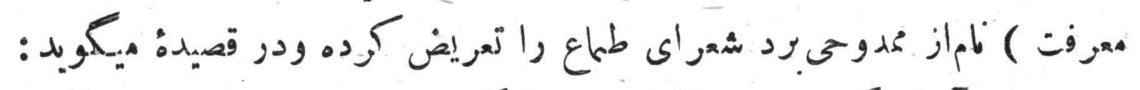

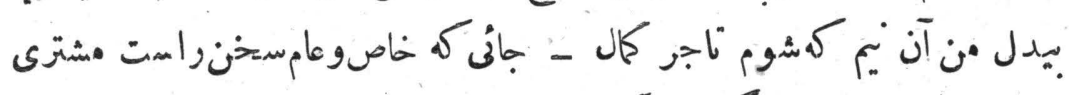

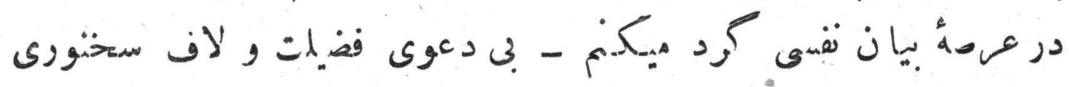

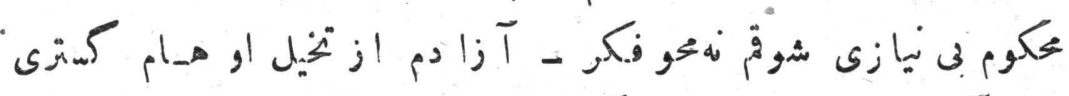

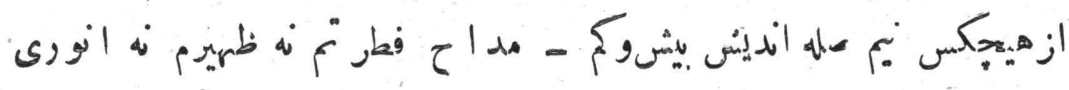




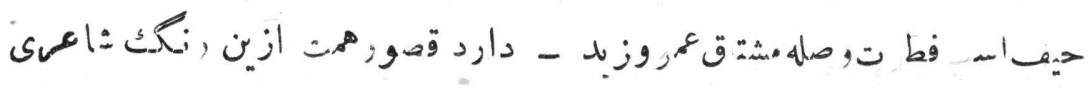

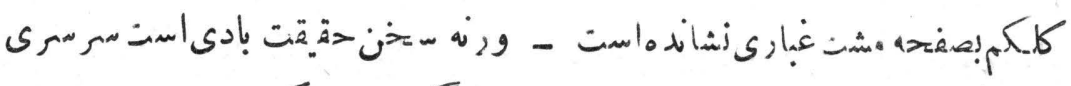

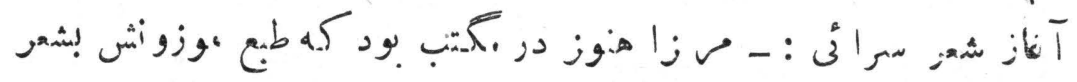

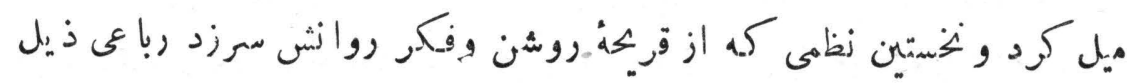

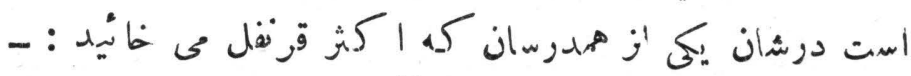

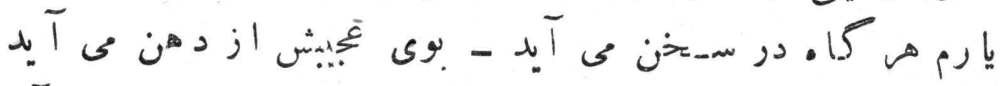

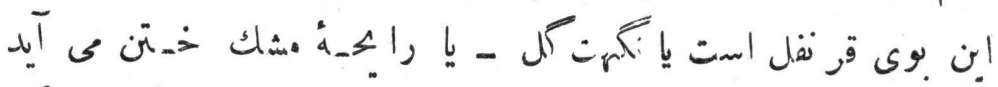

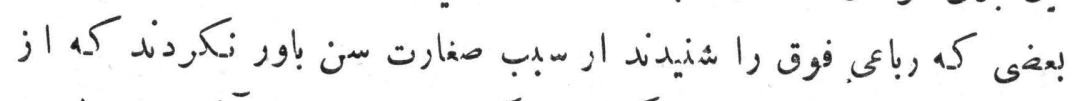

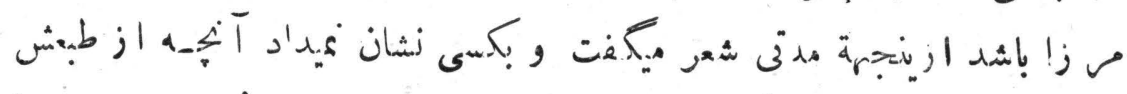

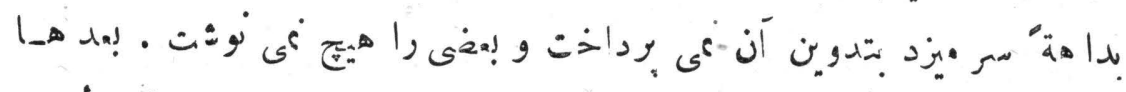

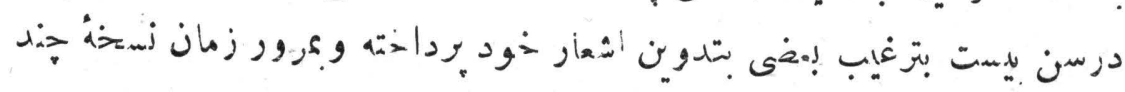

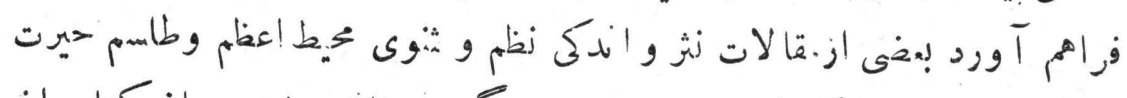

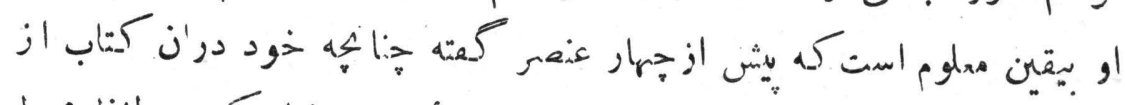

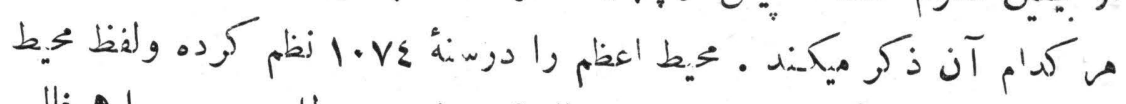

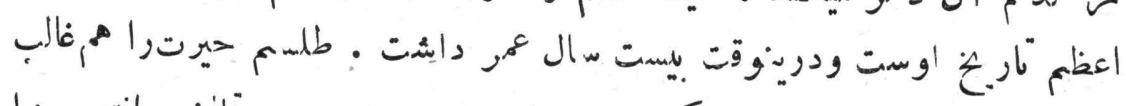

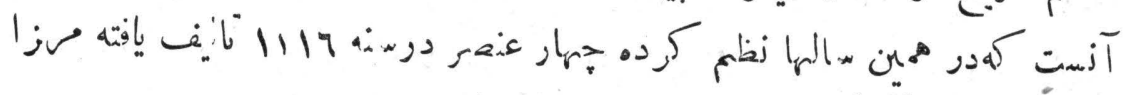

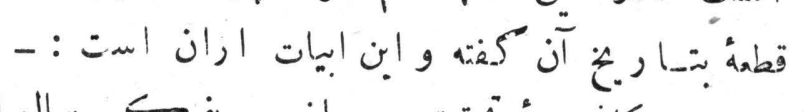

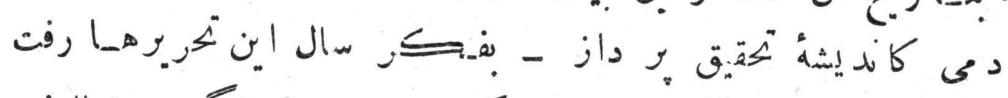

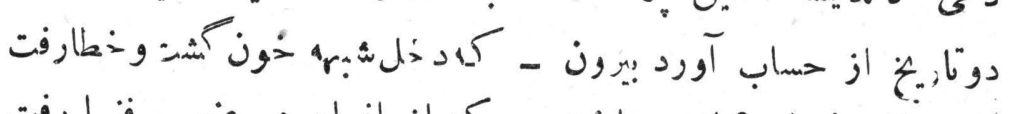

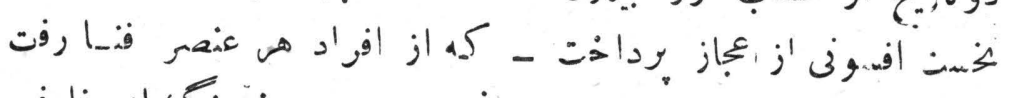

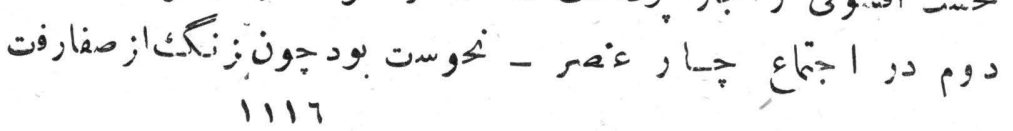




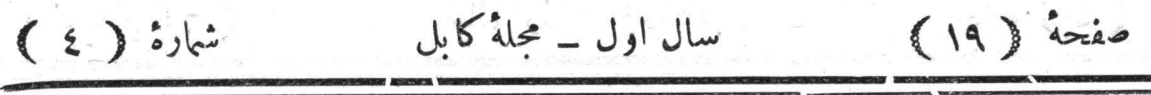

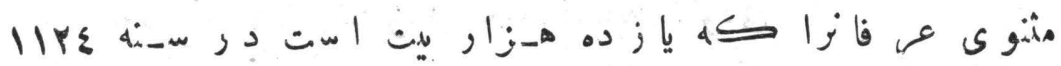

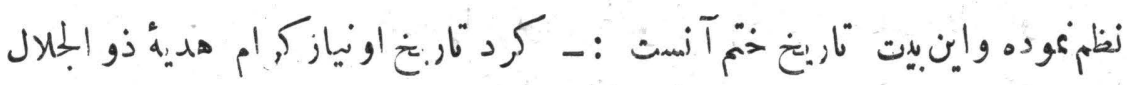
دצ

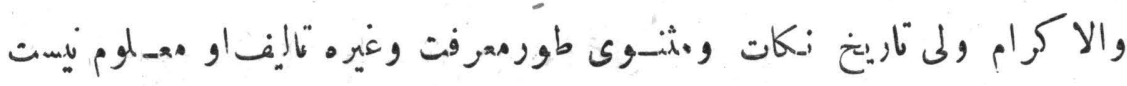

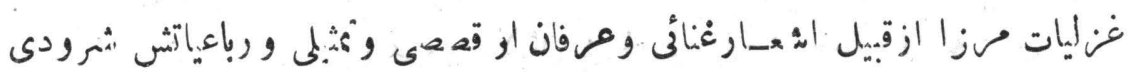

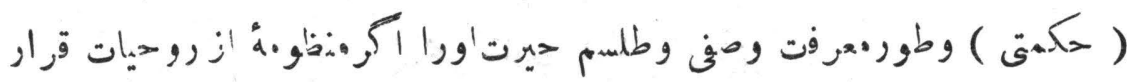

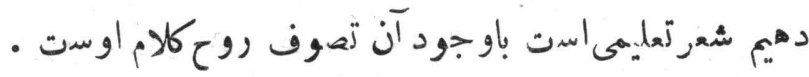

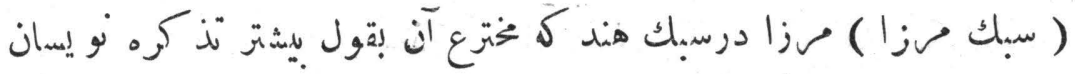

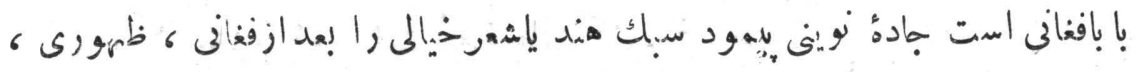

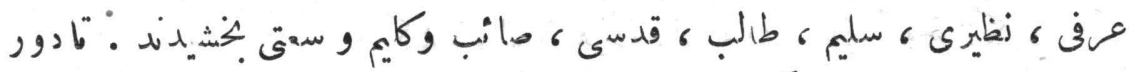

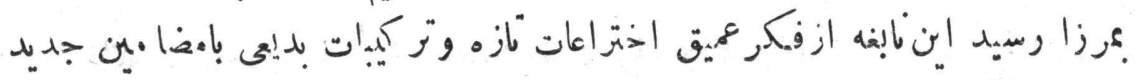

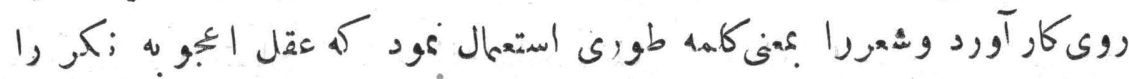

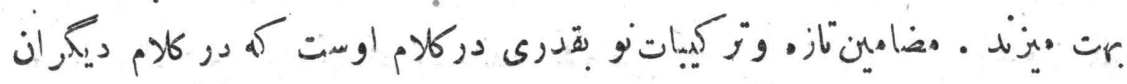

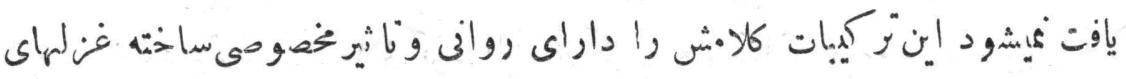

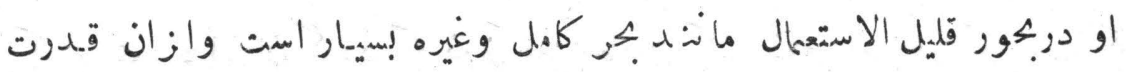

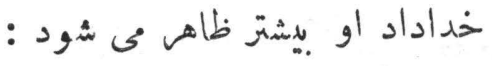

بركر كامل

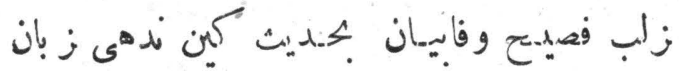

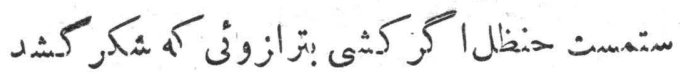

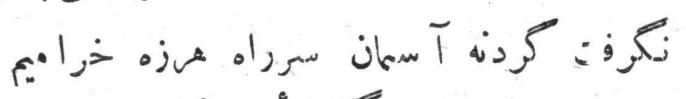

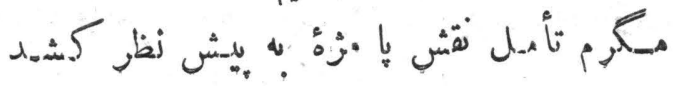




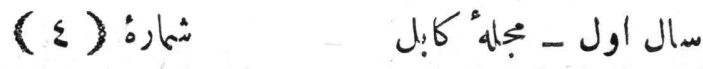

$(Y \cdot) \times 20$

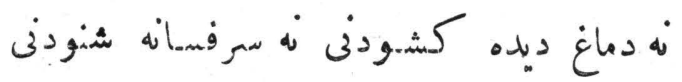

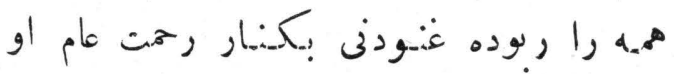

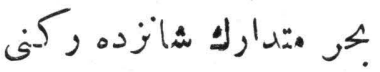

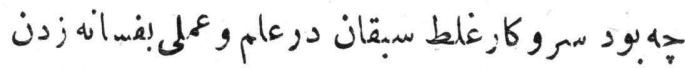

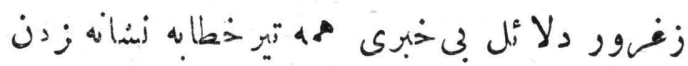

ازيحر "تقارب شانزده ركني

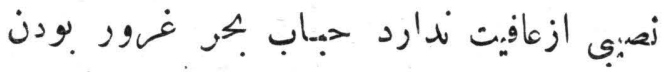

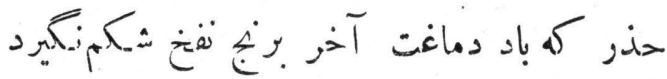

اكر بنازم بزور همت نمخجالتكش غراهت

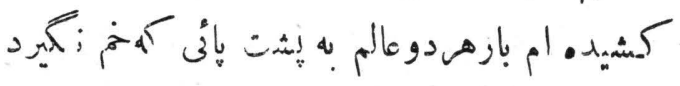

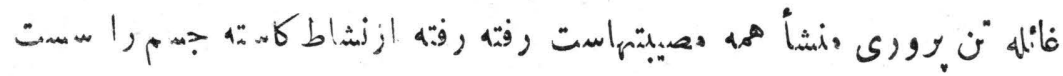

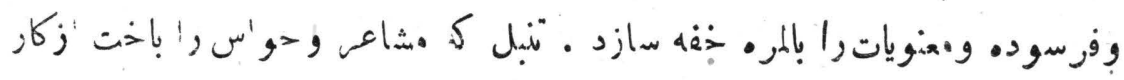

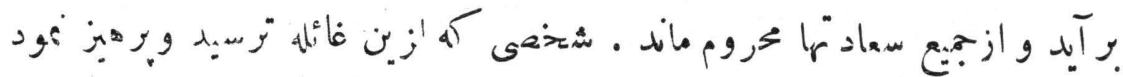

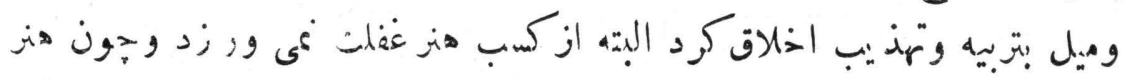

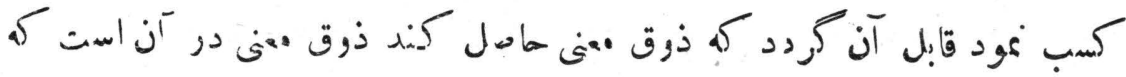

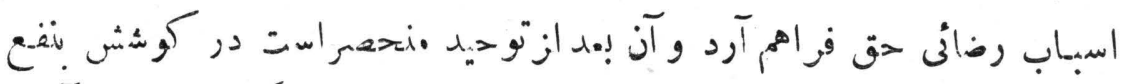

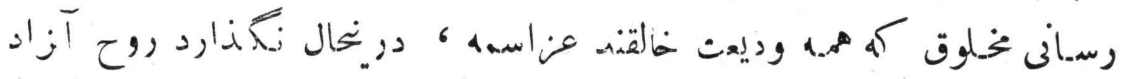

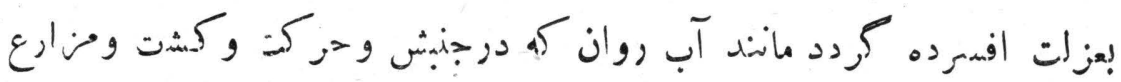

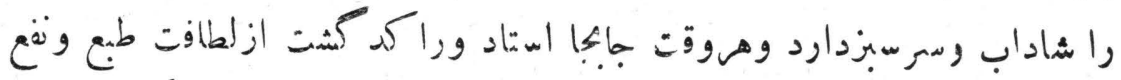

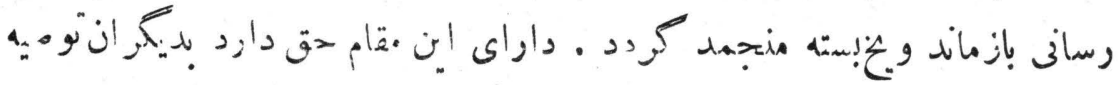

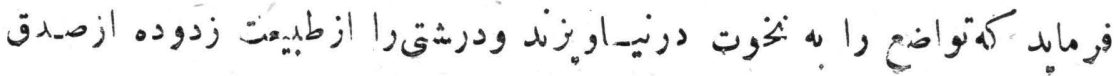




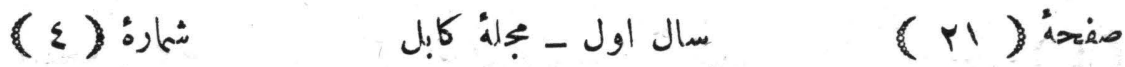

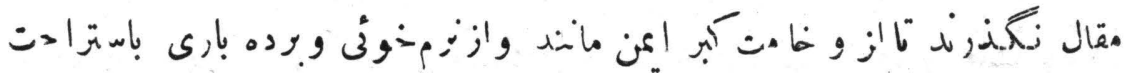

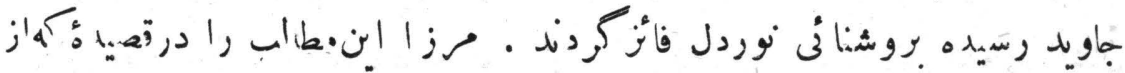

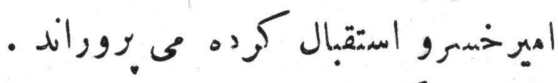

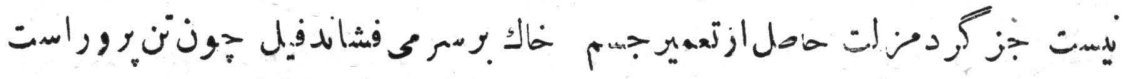

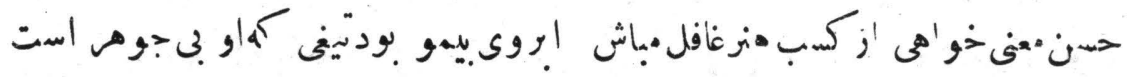

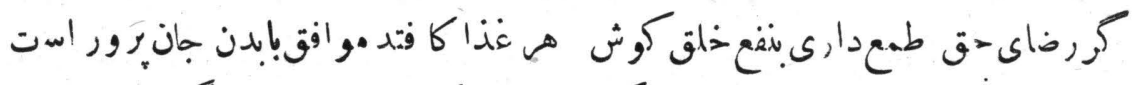

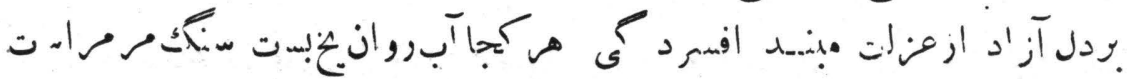

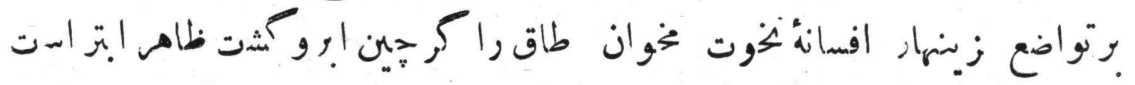

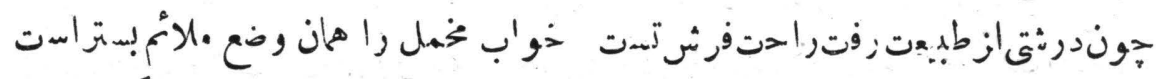

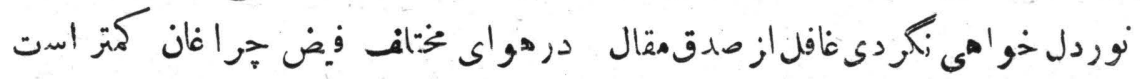
( قازى ع.دالة )

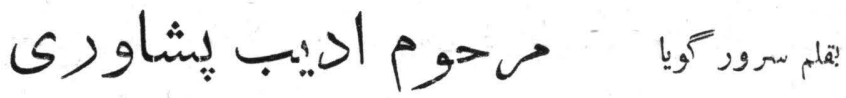

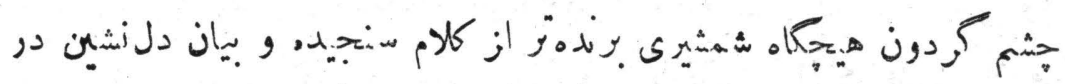

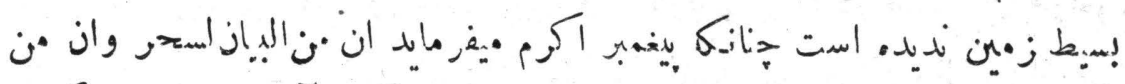

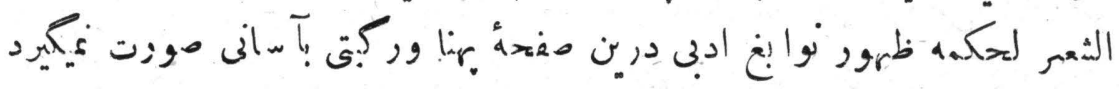

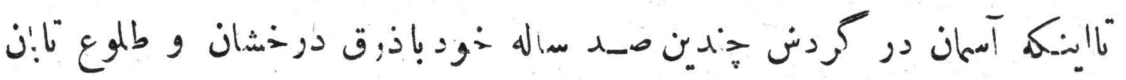

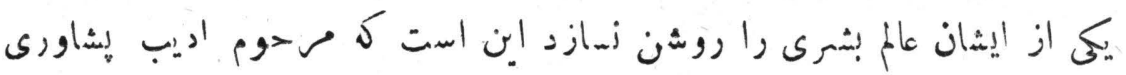

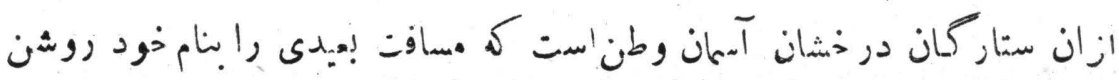

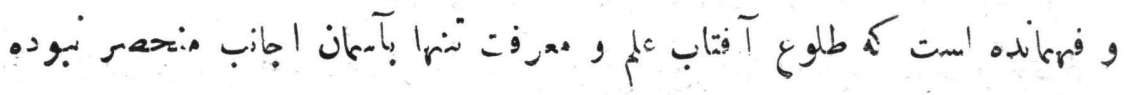




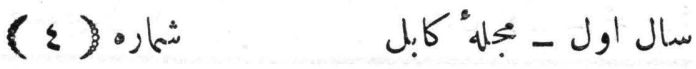

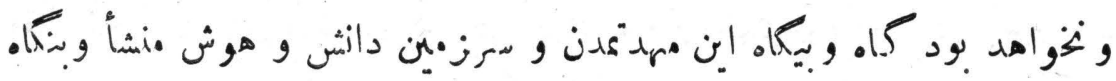

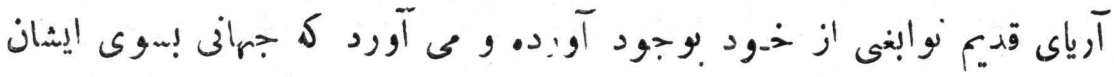

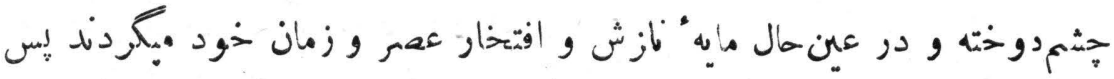

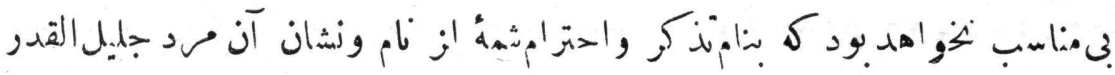

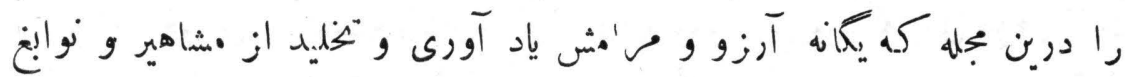

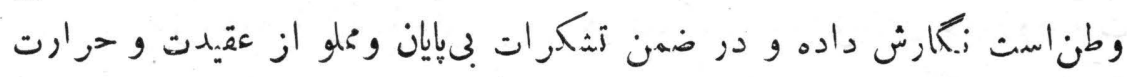

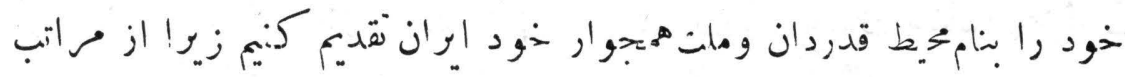

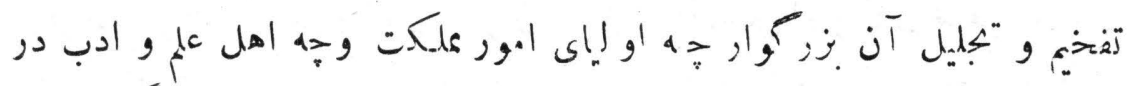

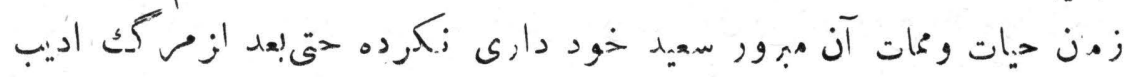

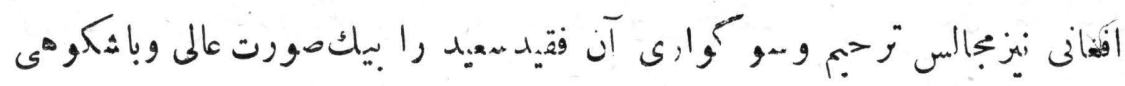

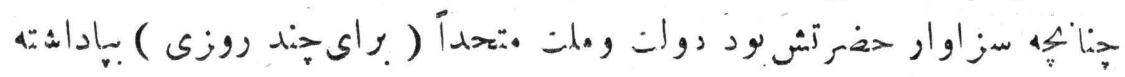

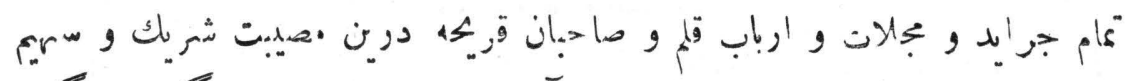

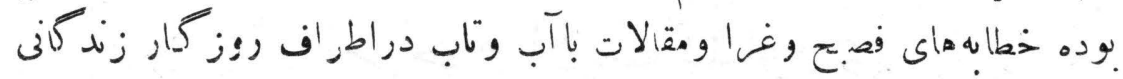

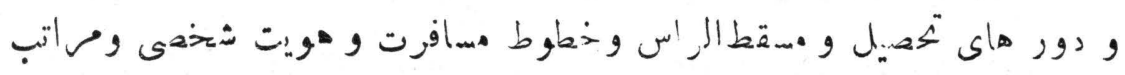

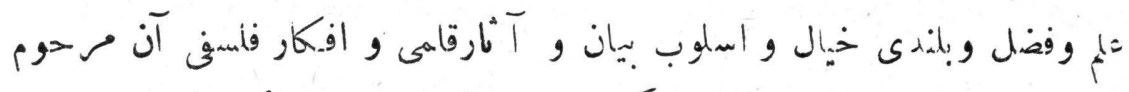

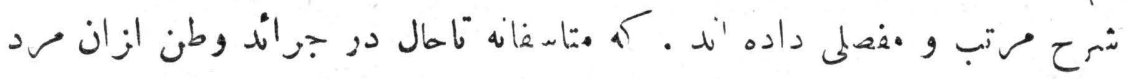

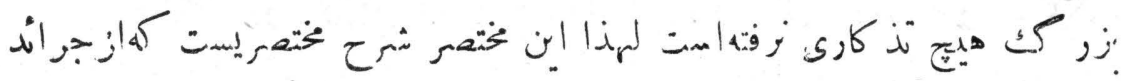

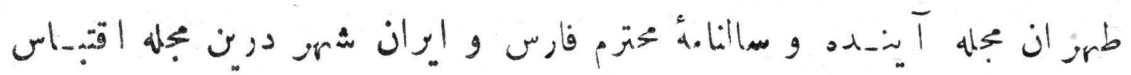

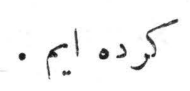

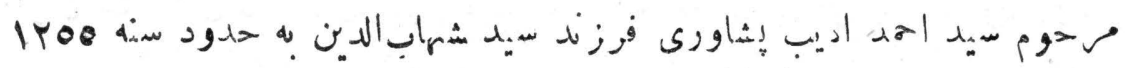

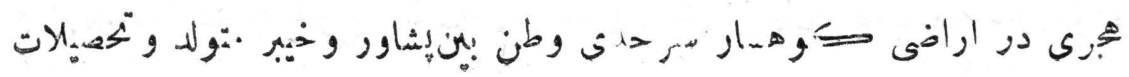




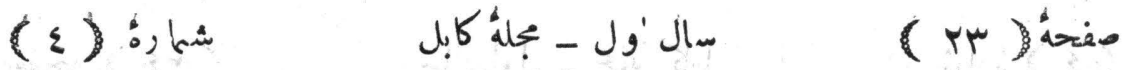

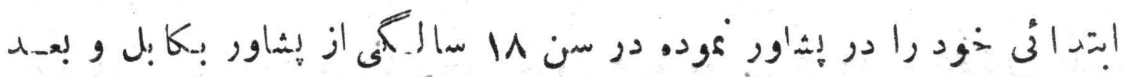

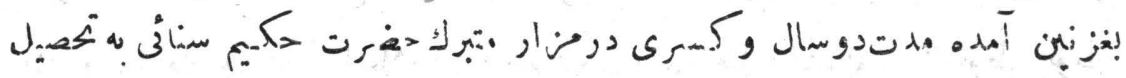

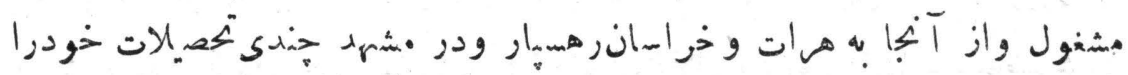

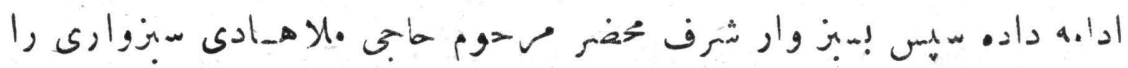

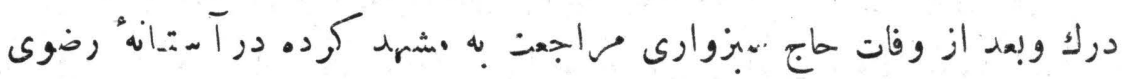

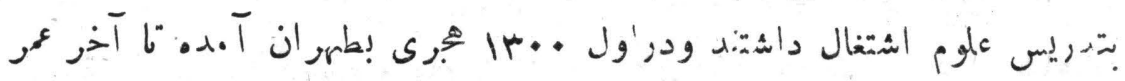

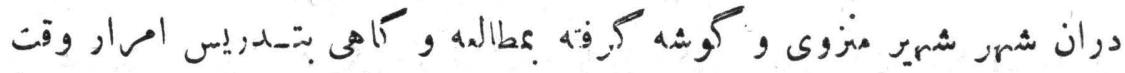

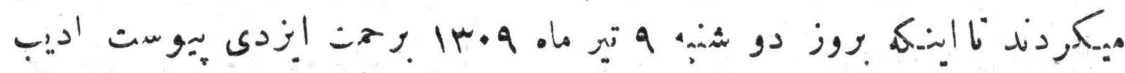

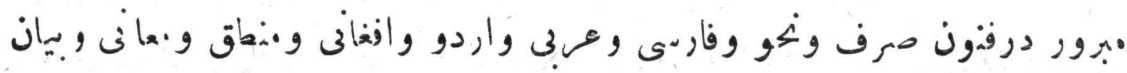

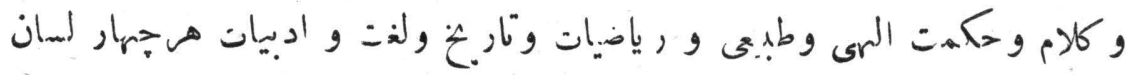

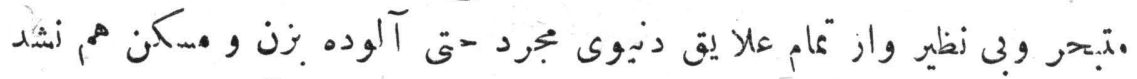

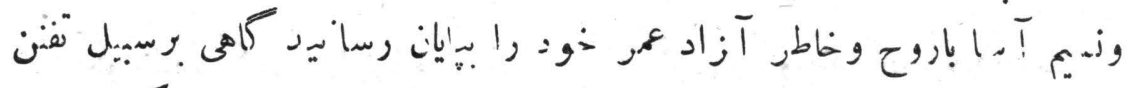

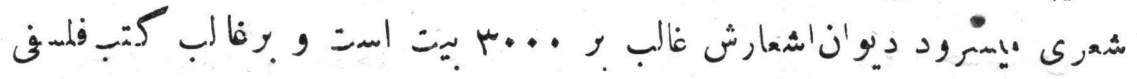

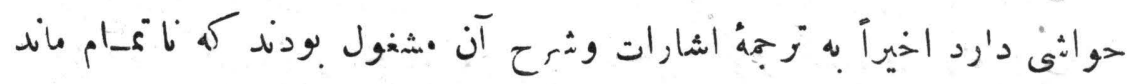

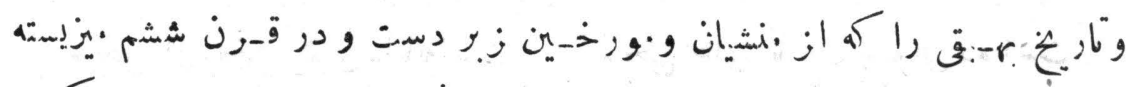

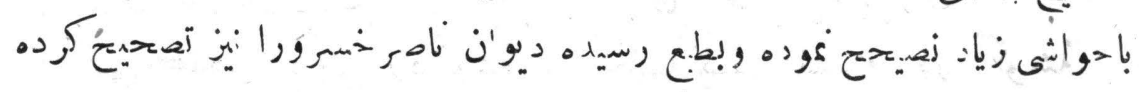

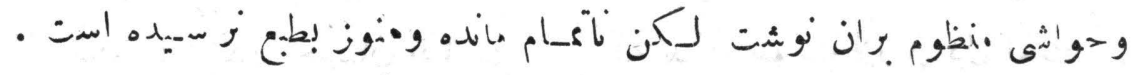

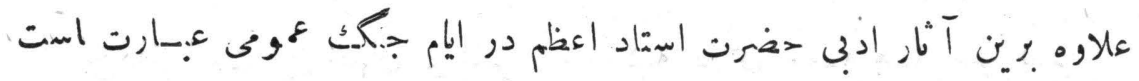

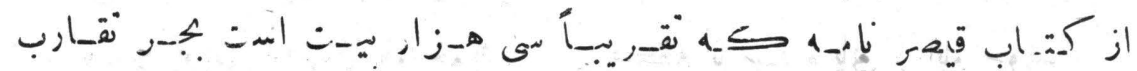

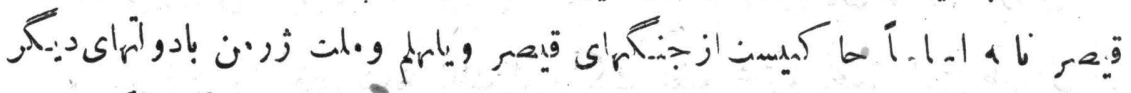

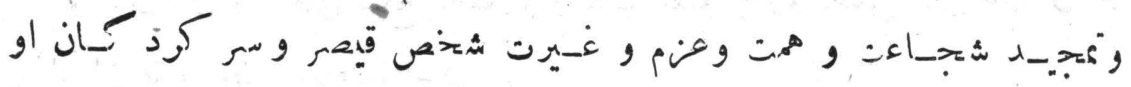




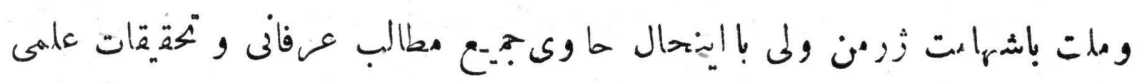

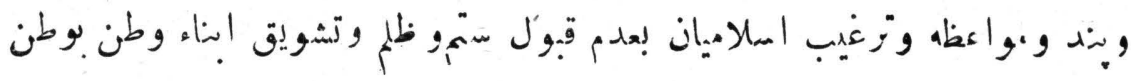

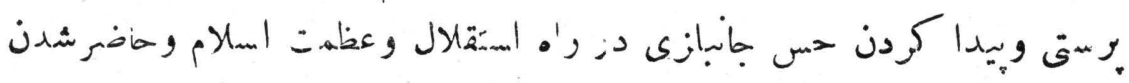

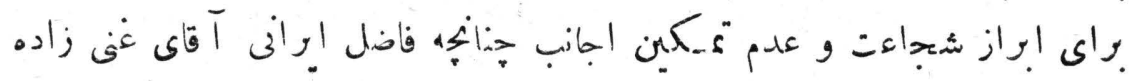

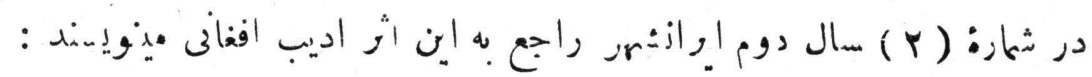

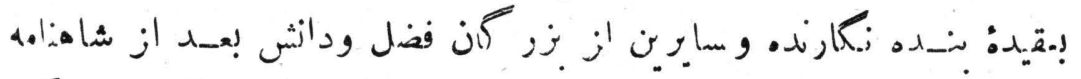

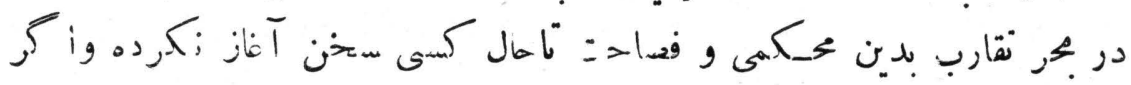

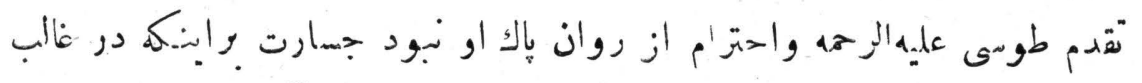

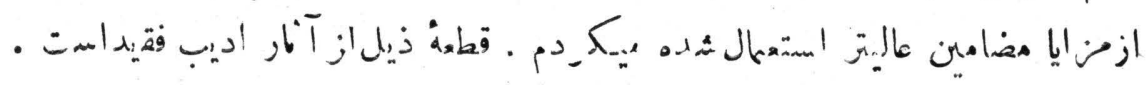

\section{دفترجمان}

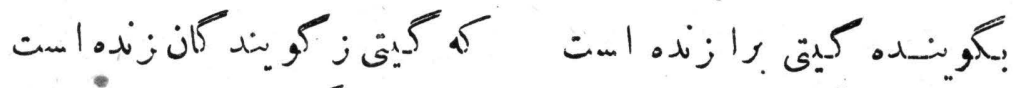

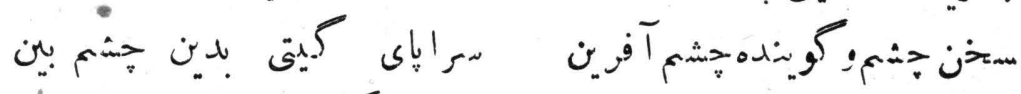

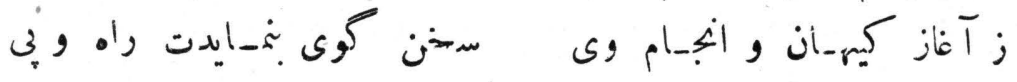

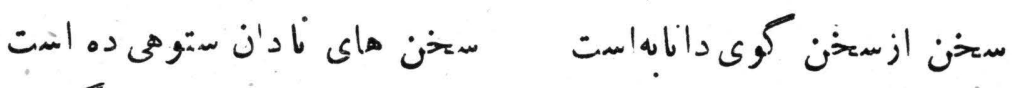

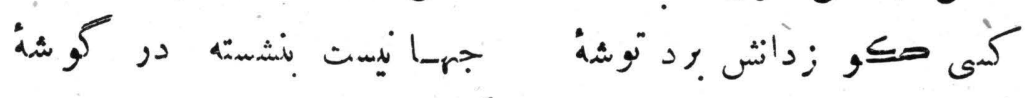
نكمو مار اندز جهـان مقبلهت

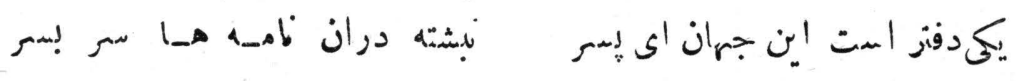

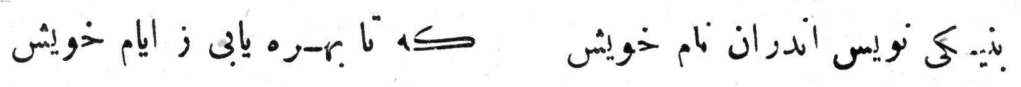

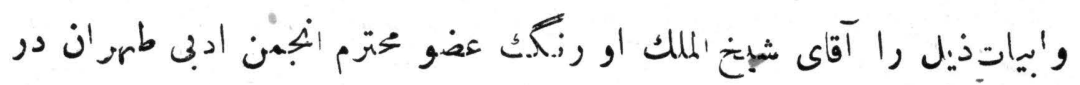

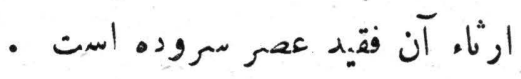




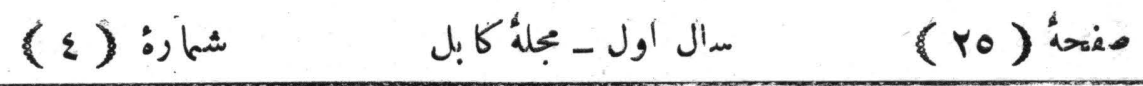

حرثية اليب

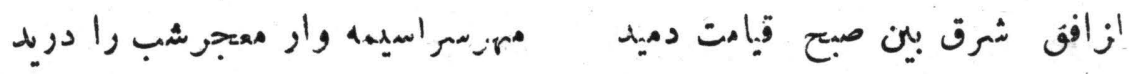

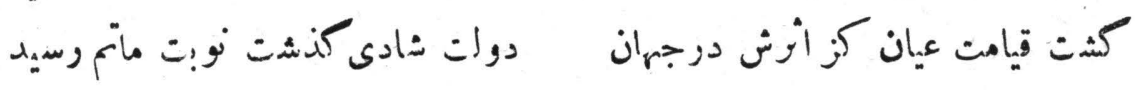

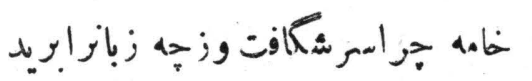

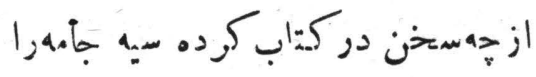

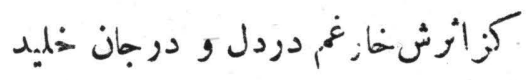

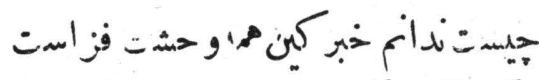

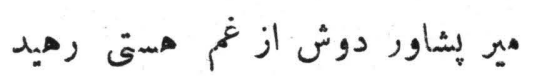

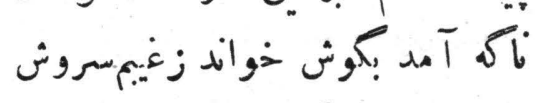

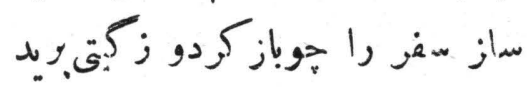

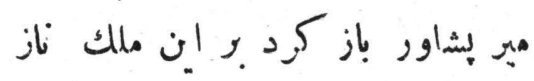

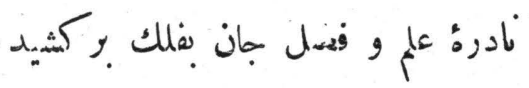

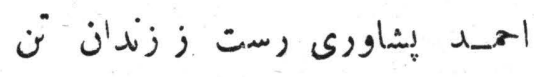

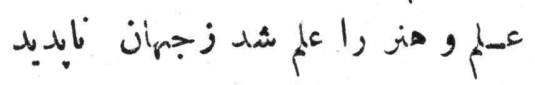

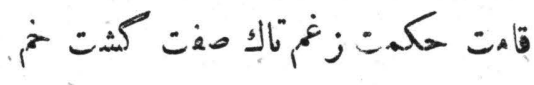

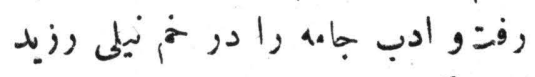

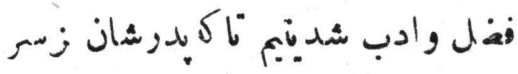

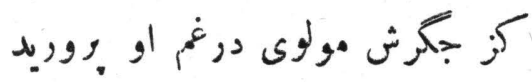

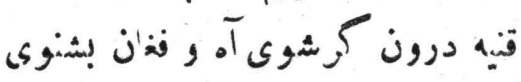

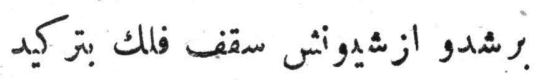

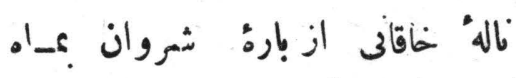

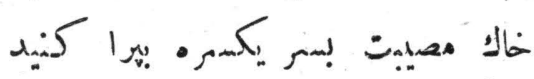

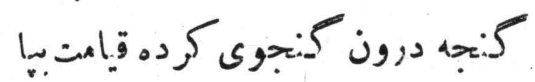

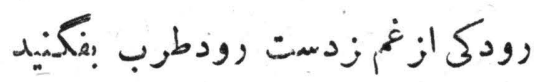
ززبت فردوسى از خون دلش لعل فام

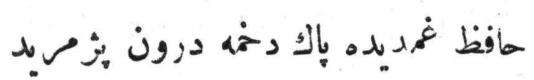

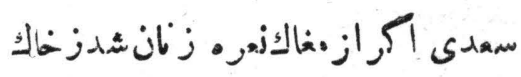
ناصر رابسكه خون ازبن مز كاني جهيد درو: ككان درون جماله شده لعل كون

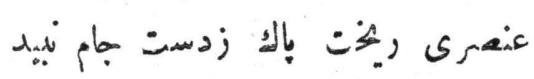

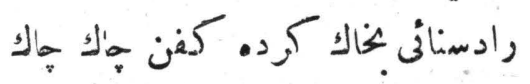

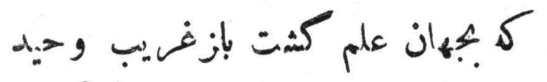

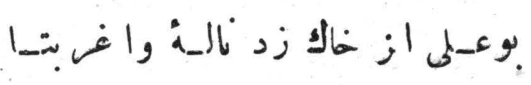

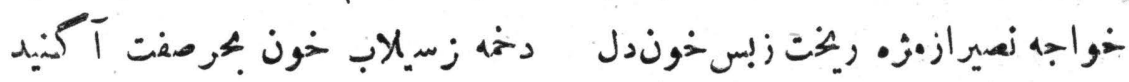

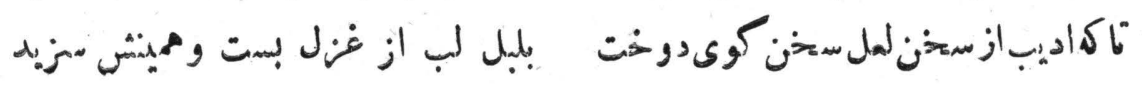




\section{مال اول - مجلة كابل}

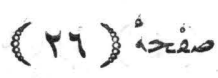

فَرى از شاخ سمرو دربن هاهى خزيد

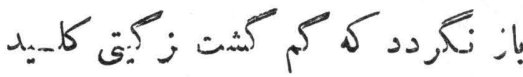

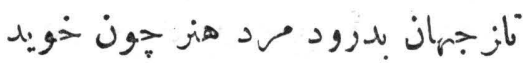

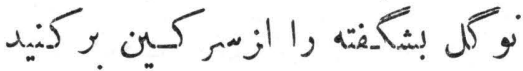

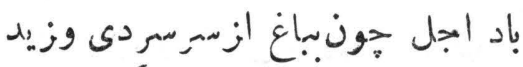

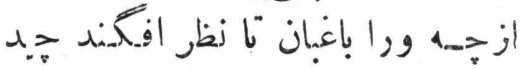

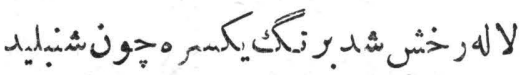

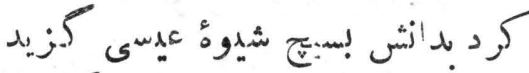

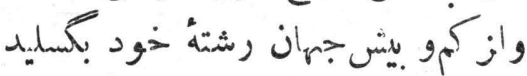

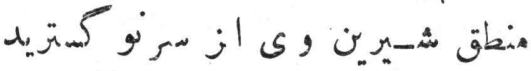

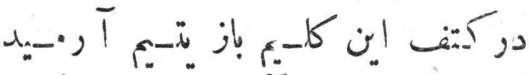

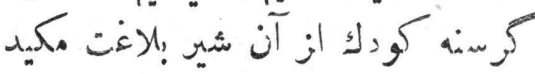

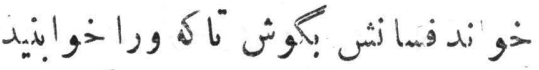

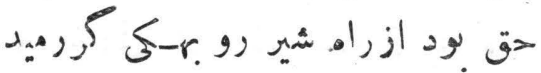

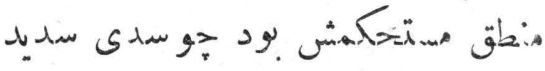

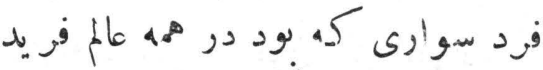

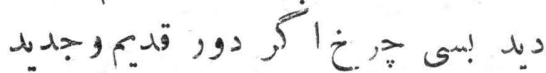

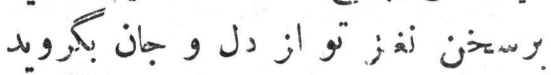

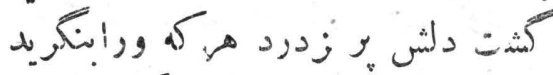

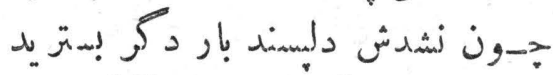

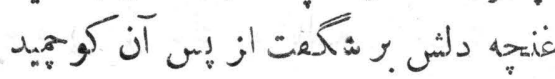

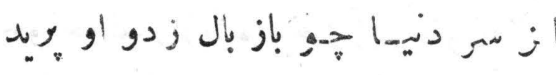

كنين انشبسو خت كثت بويشان هزار

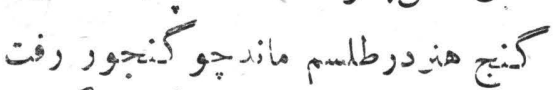

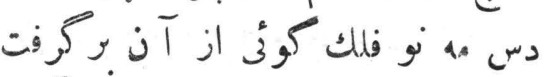

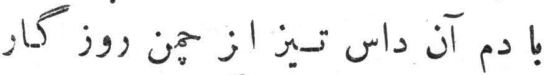

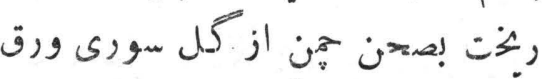

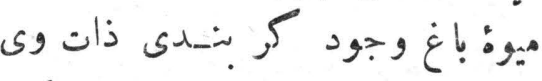

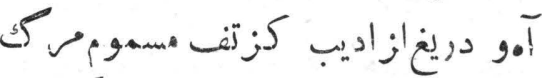

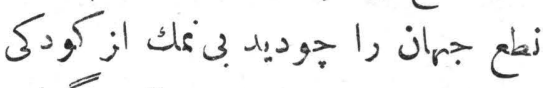

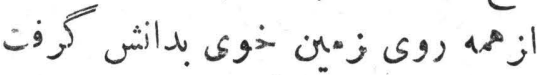

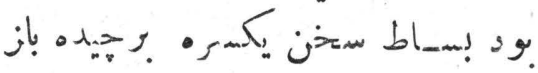

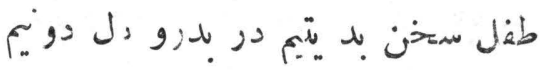

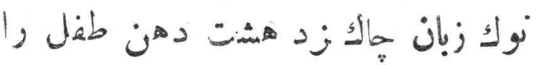

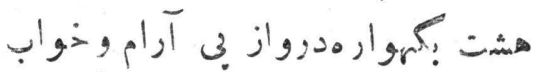

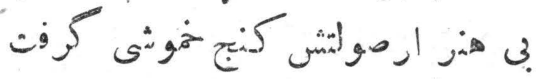

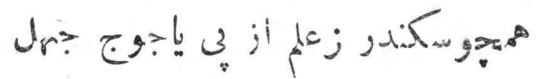

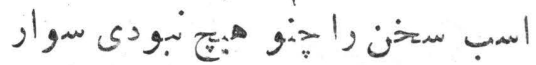

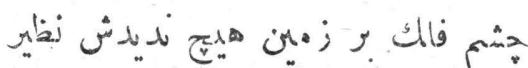

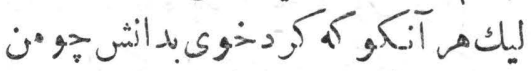

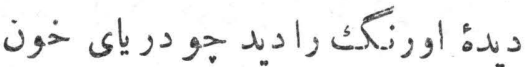

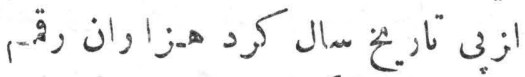

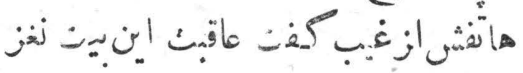

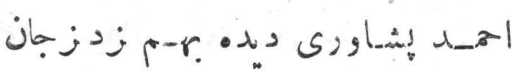
همبرى 


\section{تو صية باخاخلا}

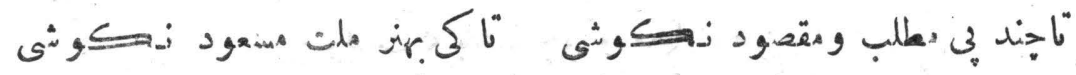

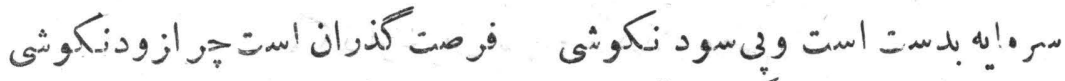

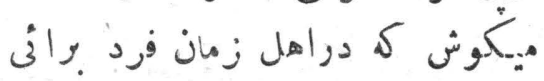

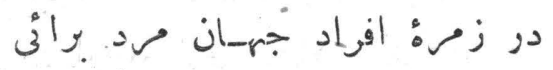

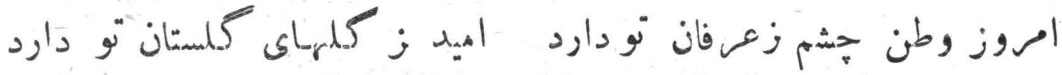

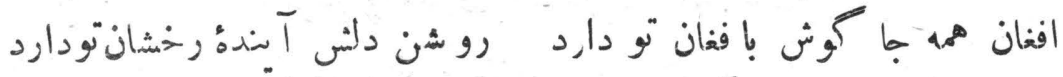

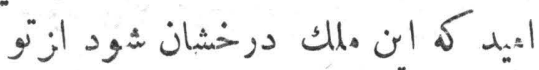

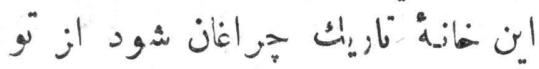

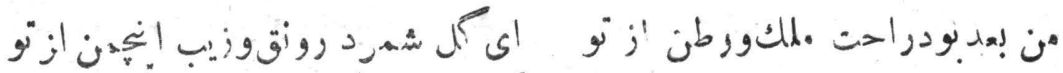

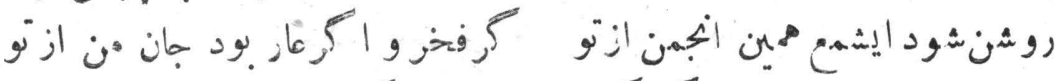

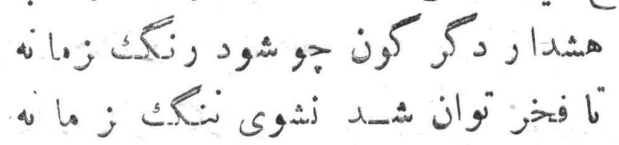

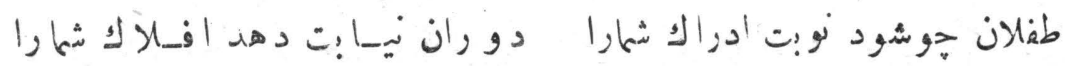

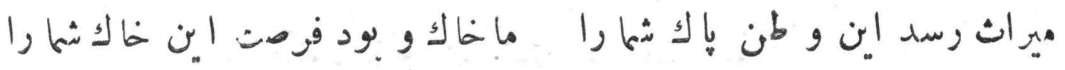

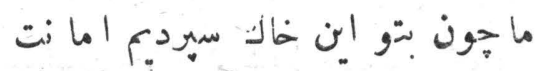

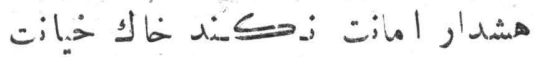

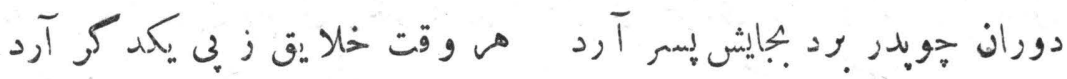

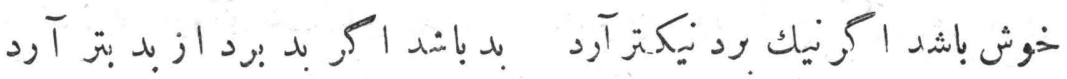

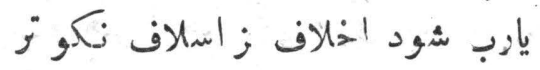

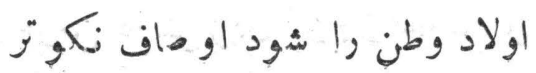




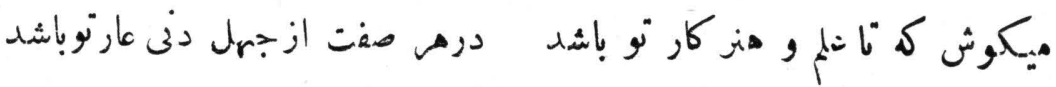

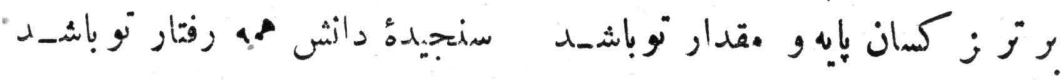

$$
\begin{aligned}
& \text { خوبستك باشد جو تو بملرار وطنرا }
\end{aligned}
$$

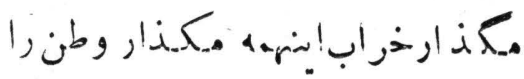

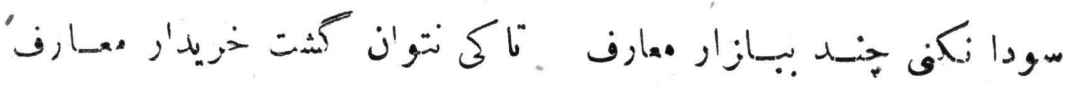

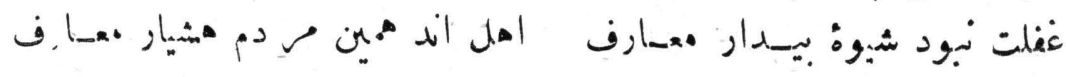

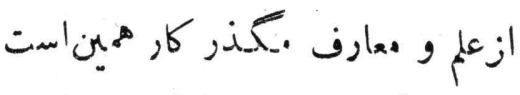

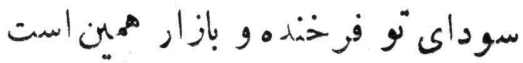

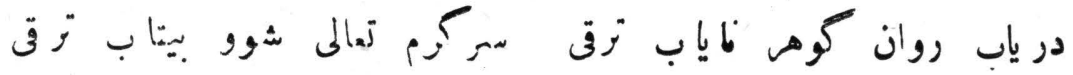

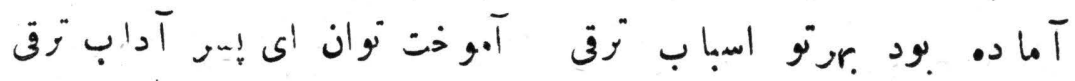

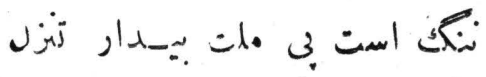

$$
\begin{aligned}
& \text { هشدار دربن عهر بود عار تنزل }
\end{aligned}
$$

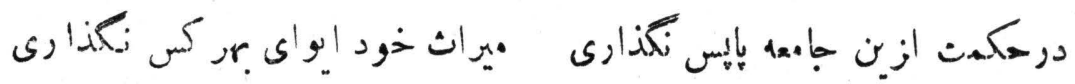

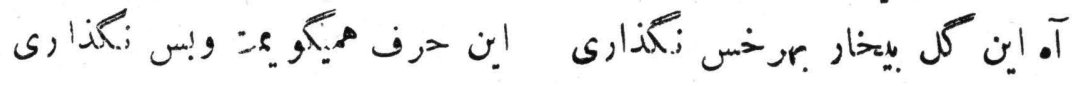

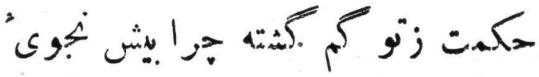

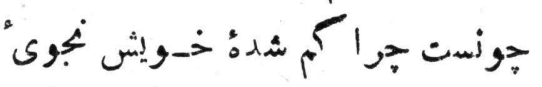

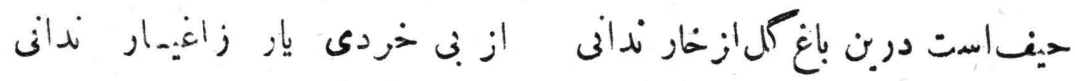

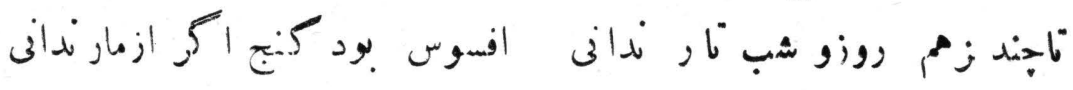

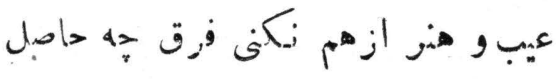

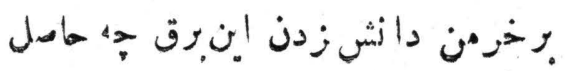


(2): :

( ra) irie

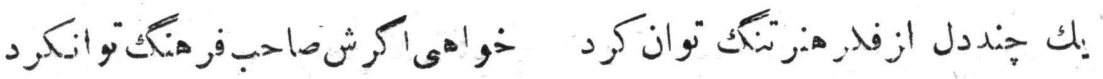

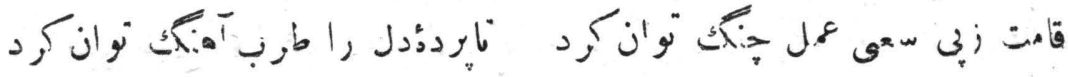

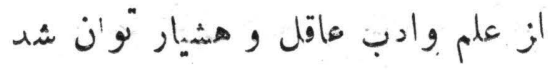

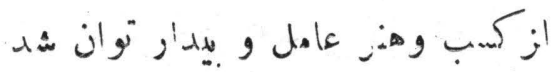

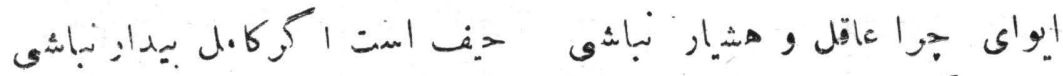

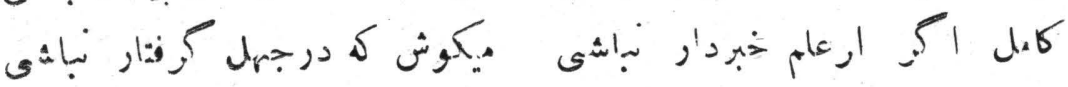

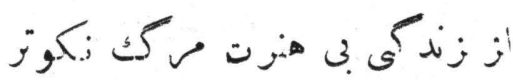

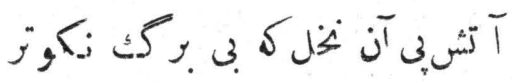

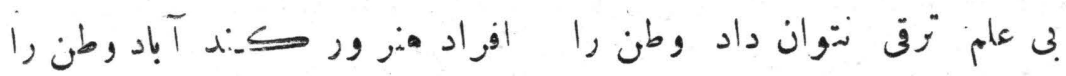

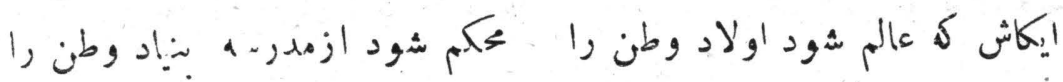

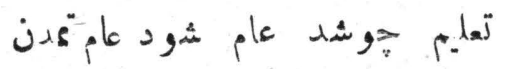

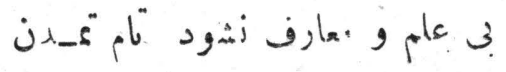

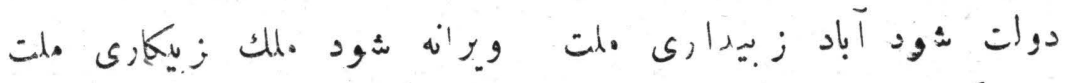

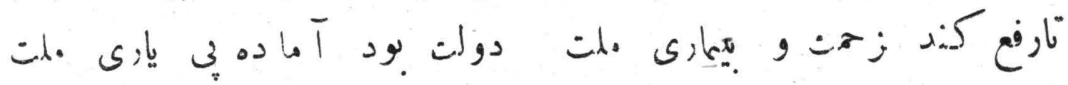

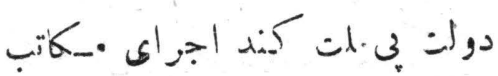

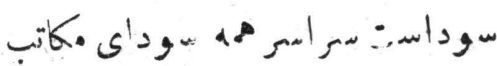

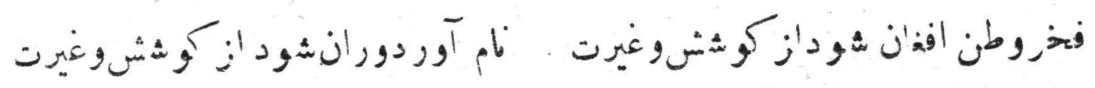

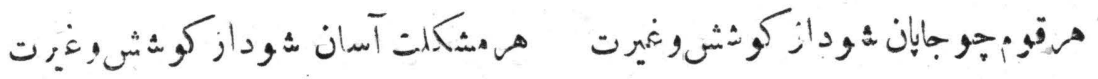

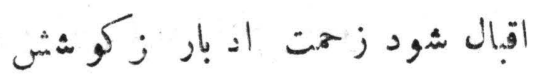

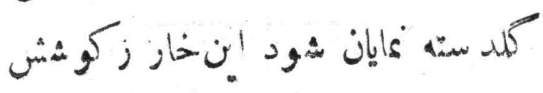




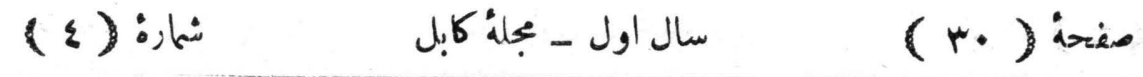

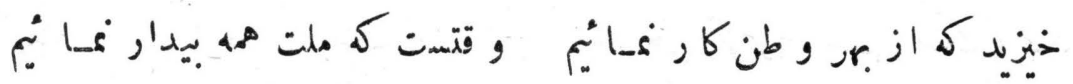

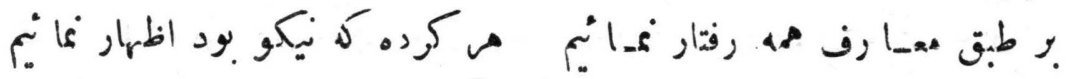

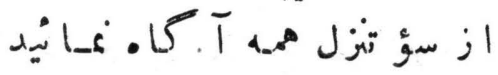

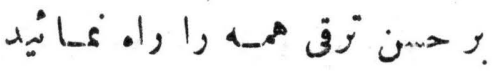

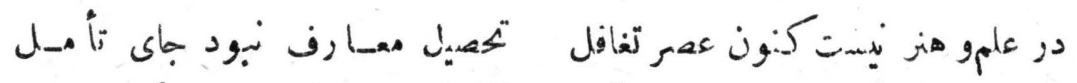

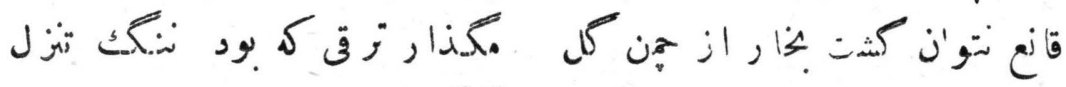

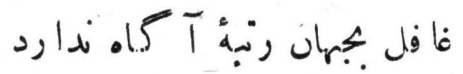

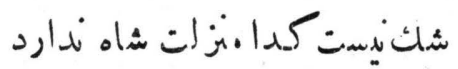

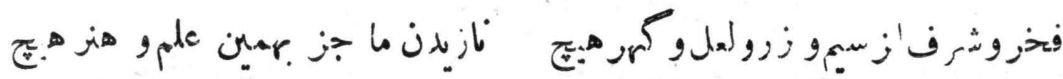

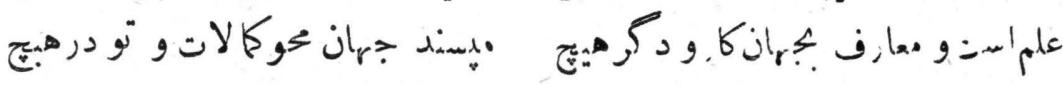

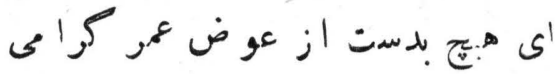

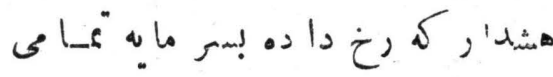

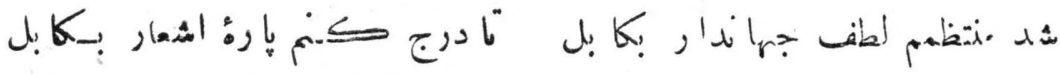

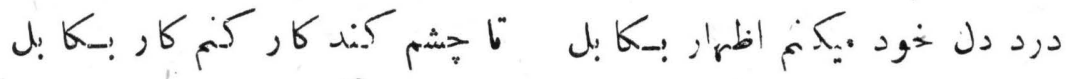

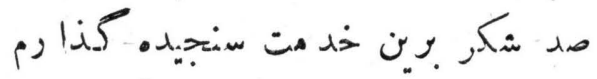

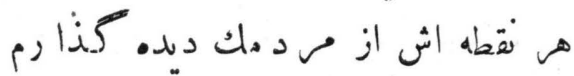

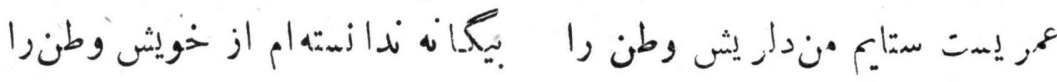

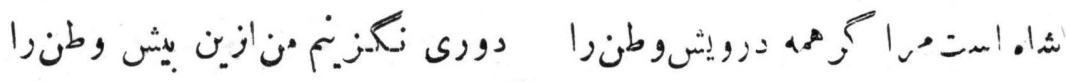

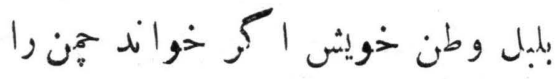

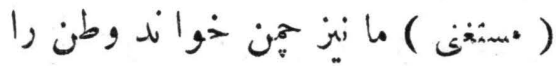




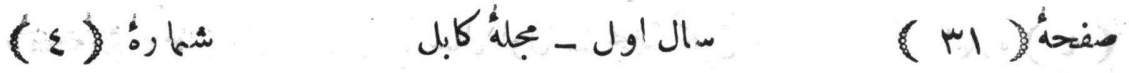

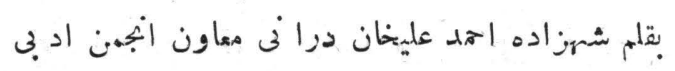

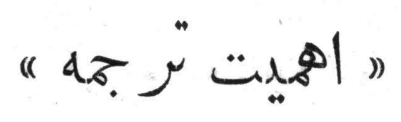

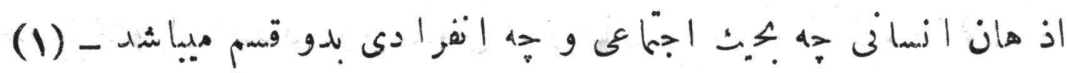

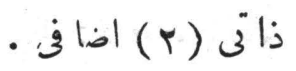

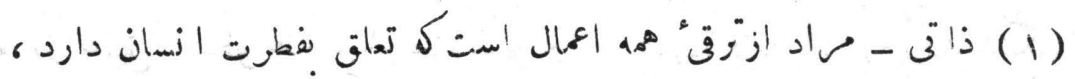

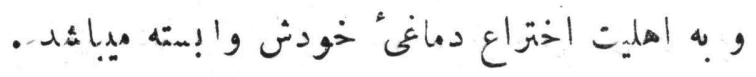

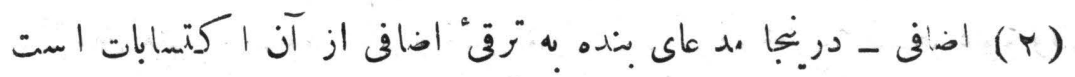

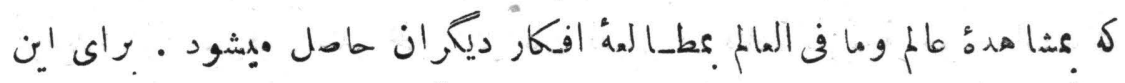

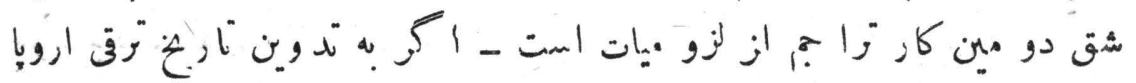

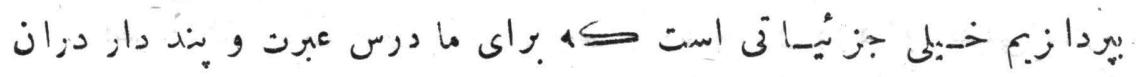

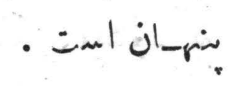

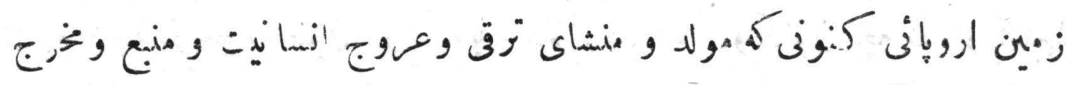

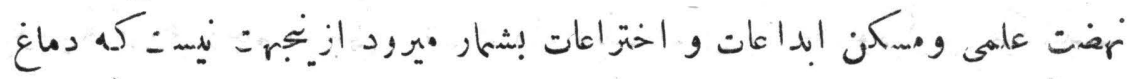

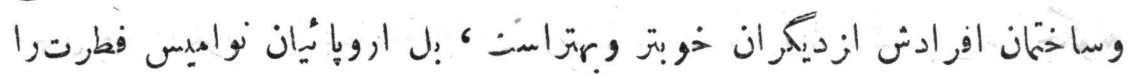

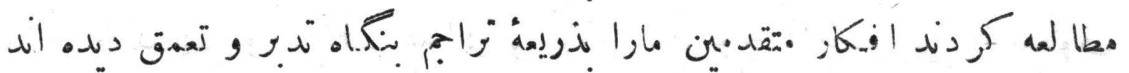

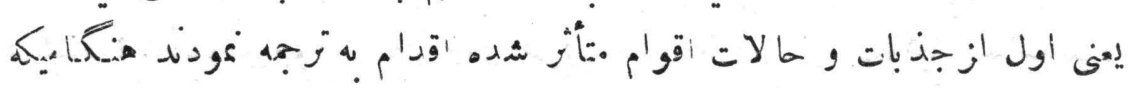

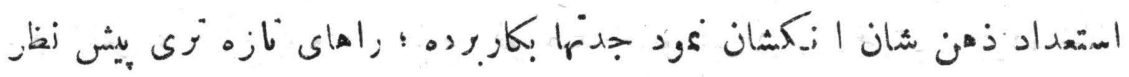

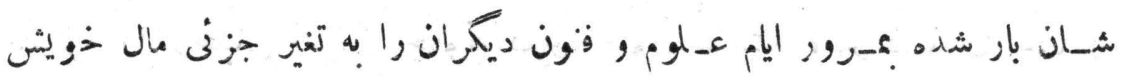

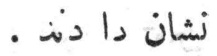




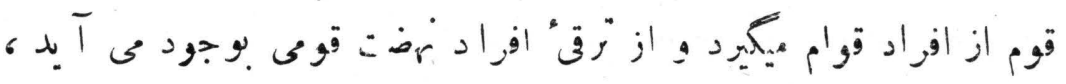

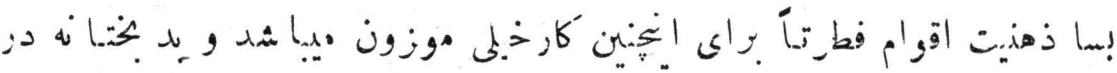

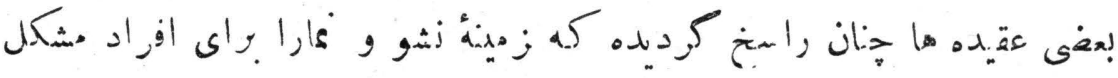

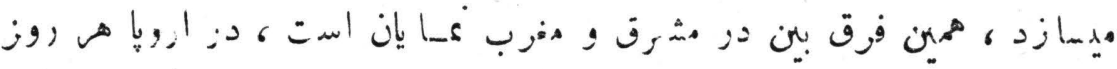

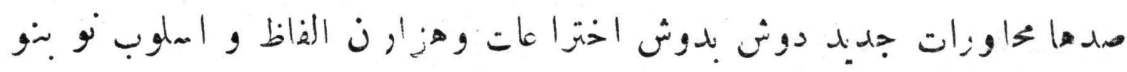

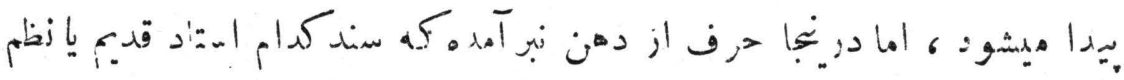

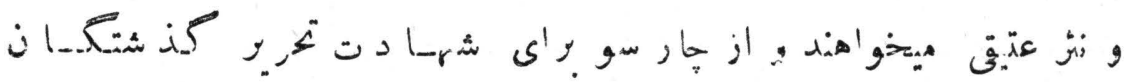

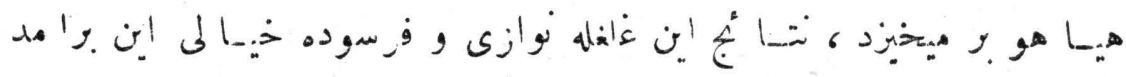

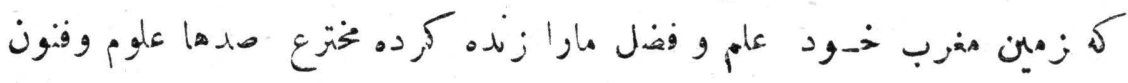

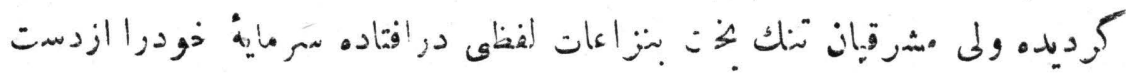

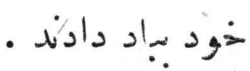

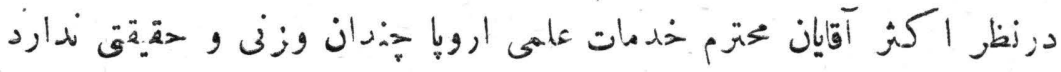

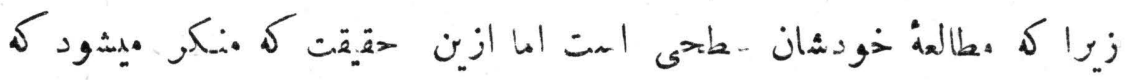

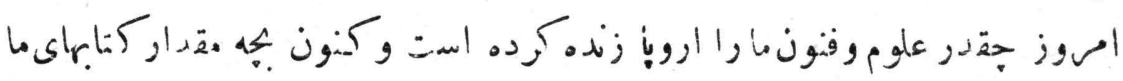

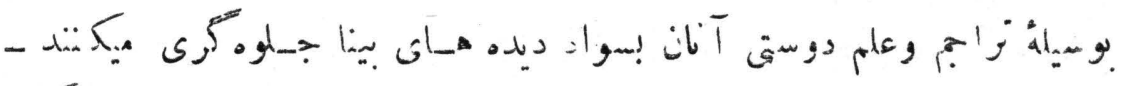

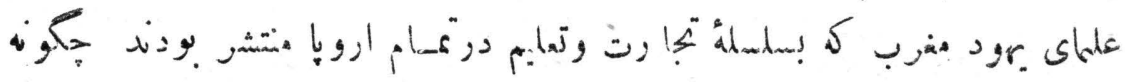

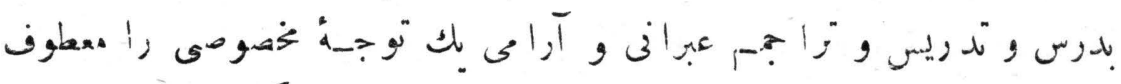

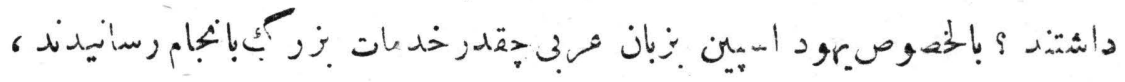

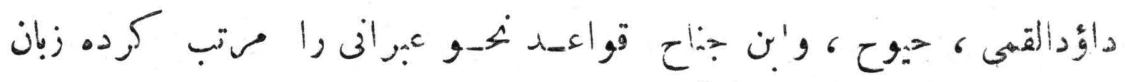

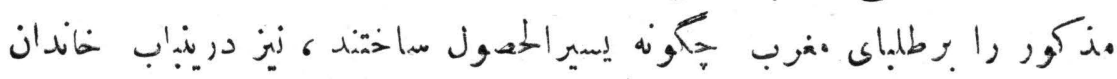

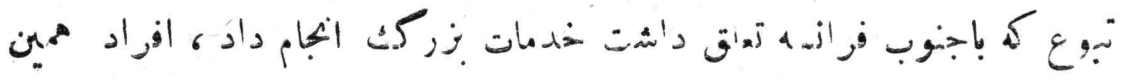




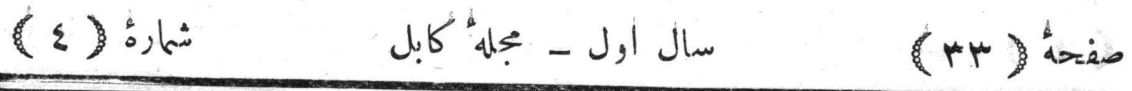

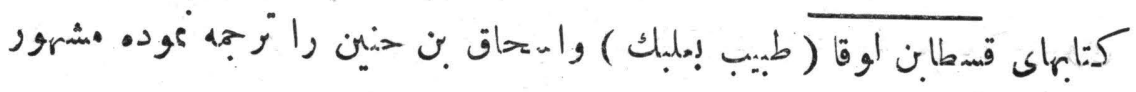

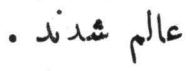

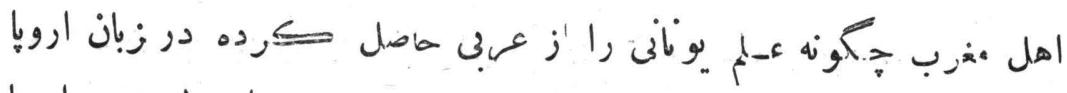

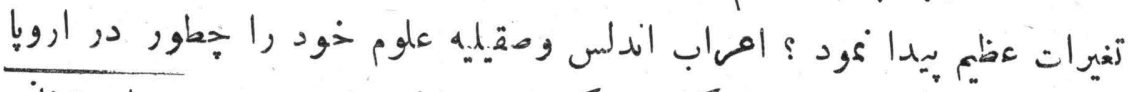

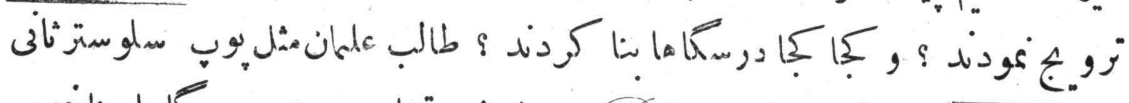

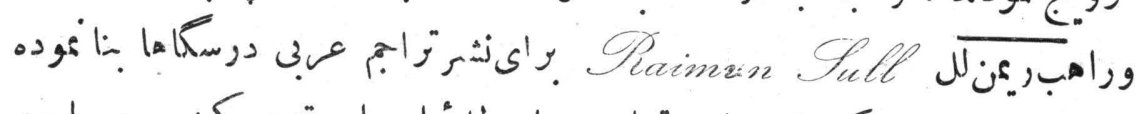

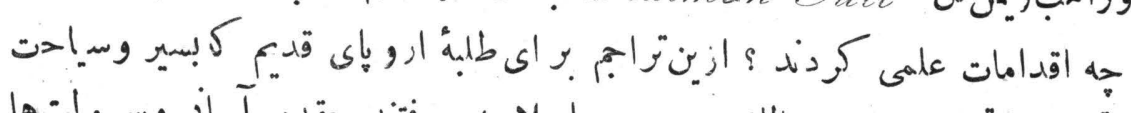

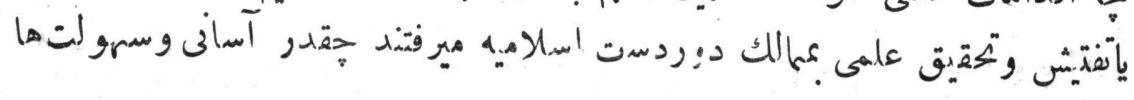

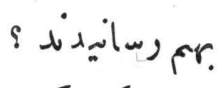

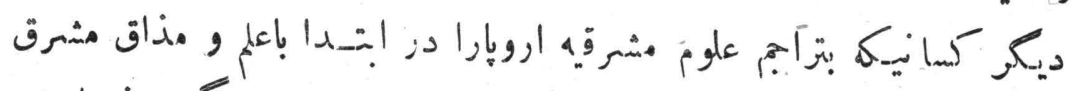

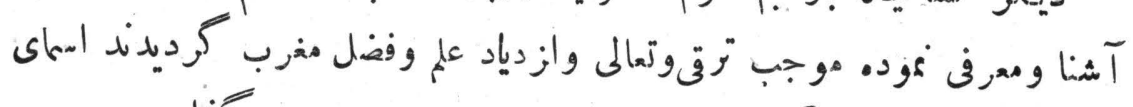

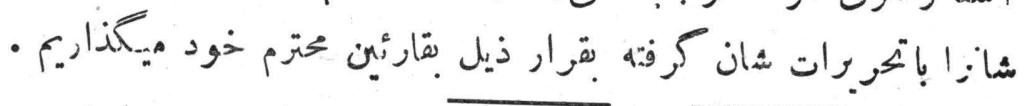
1

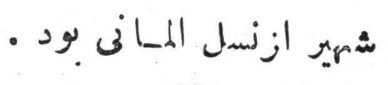

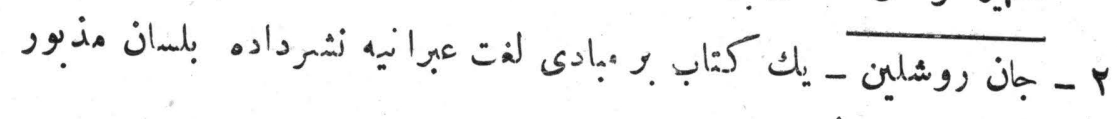

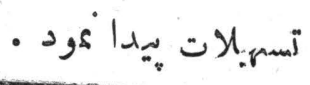

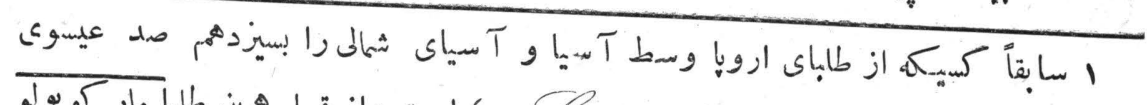

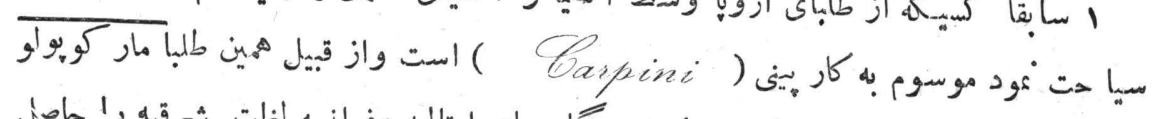

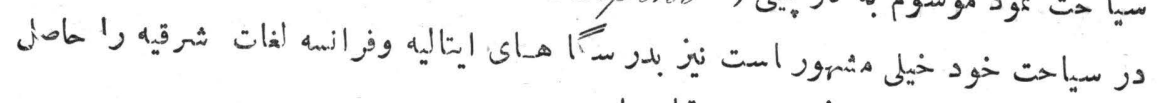

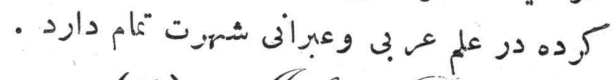

(1) Canaid. Pellicanas (r) Gohn Pinchlin 


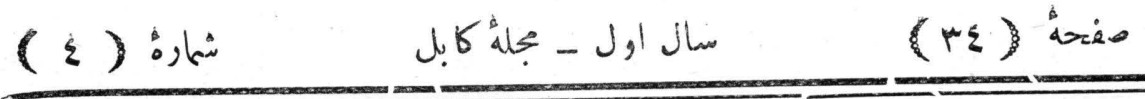

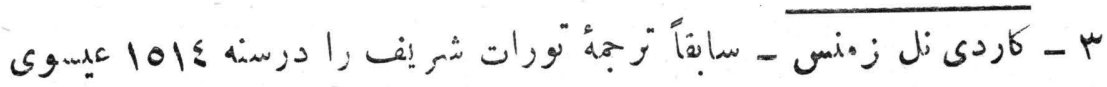

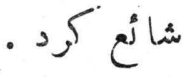

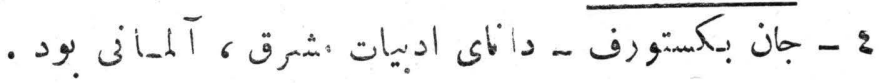

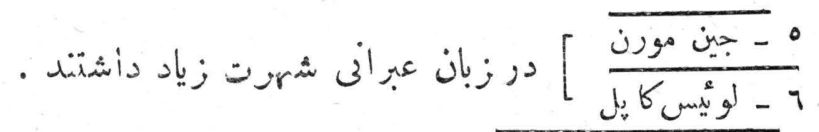

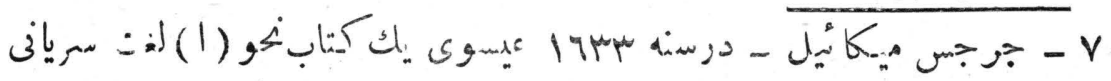

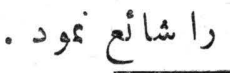

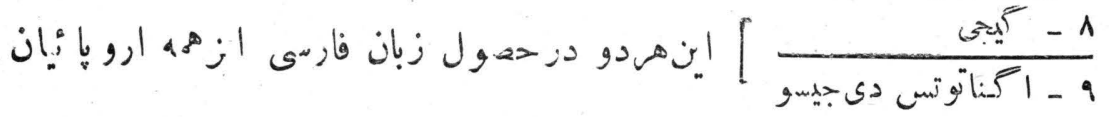

سمقت دارند د د

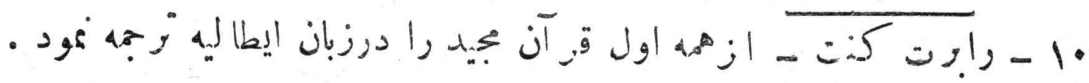

. - 11

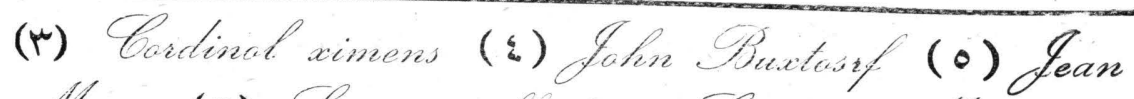

Harin ( v) Lanis capelle (V) Geijies Nicaiel.

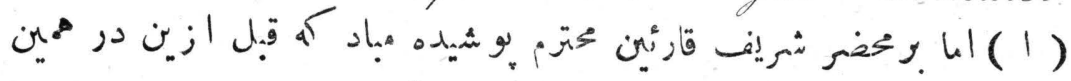

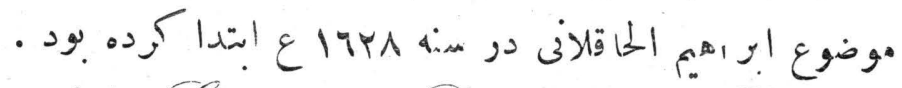

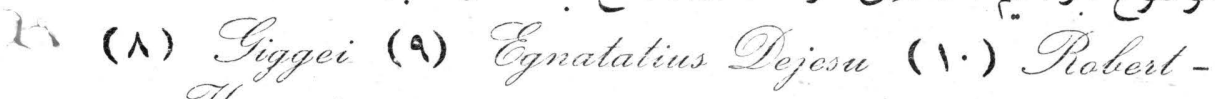
Rennet -

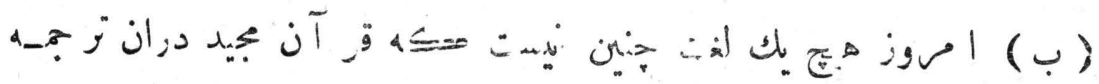

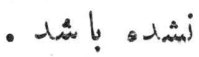

(11) Sale 


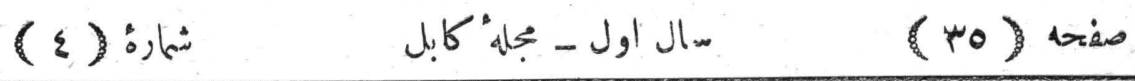

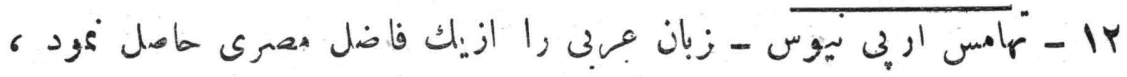

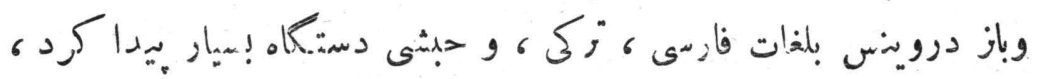

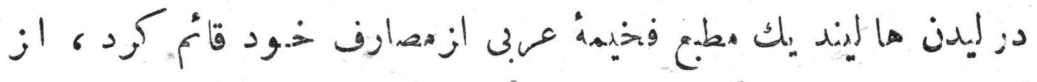

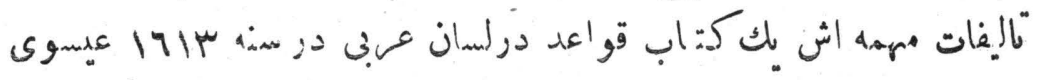

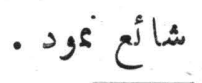

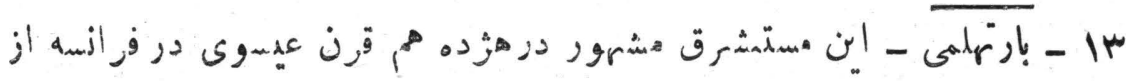

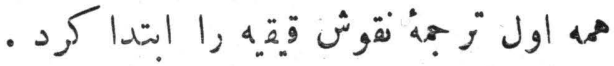

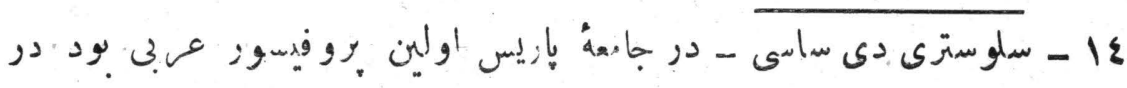

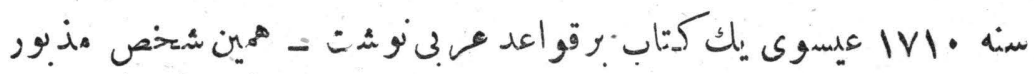

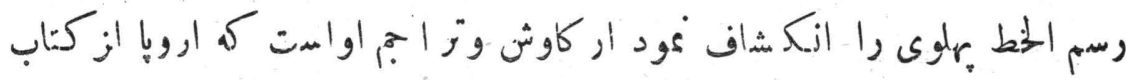

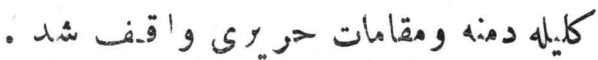

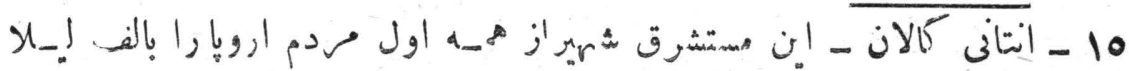

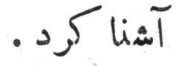

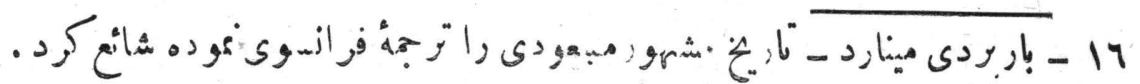
(ج)

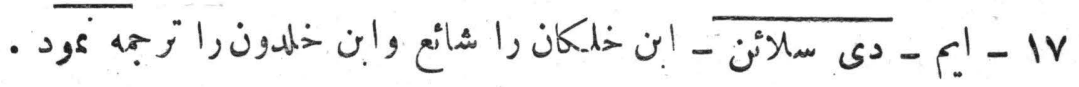

(ir) Lhamas Caponiux (Ir) Brathelmy

(IE) Sylasestre Gevorg (10) Alitaine Gallant

(1v) Draber de Aleypraid (Iv) M. OD. Slane

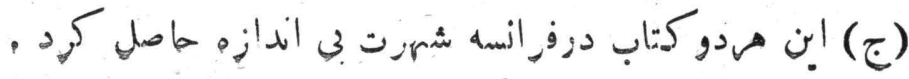




\section{سال الول - مجلهُ كابل}

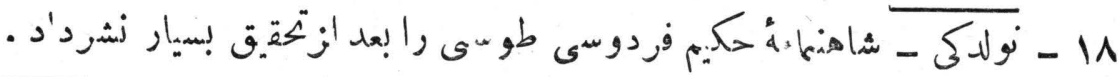

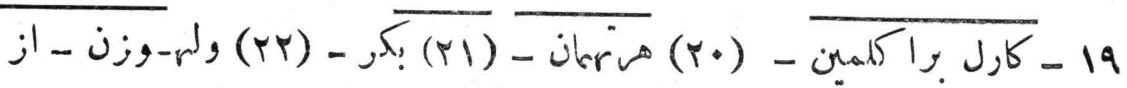

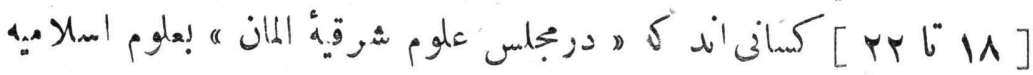

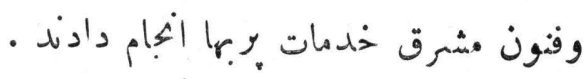

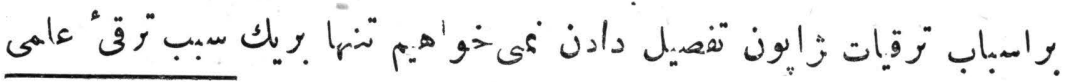

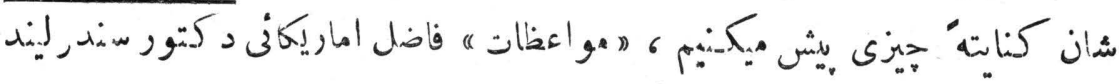

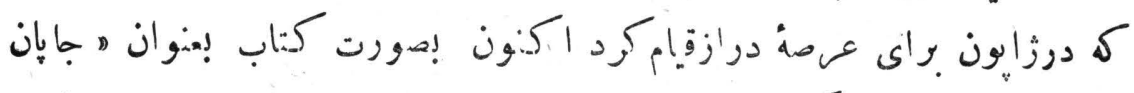

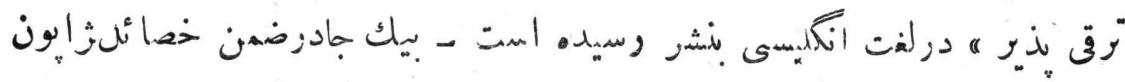

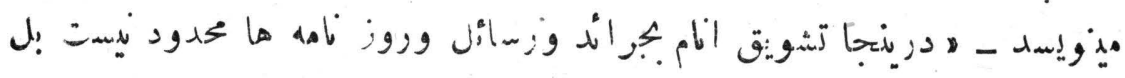

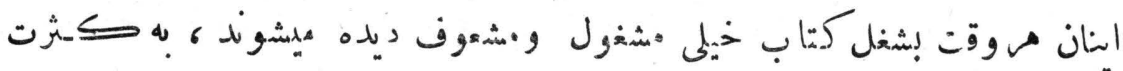

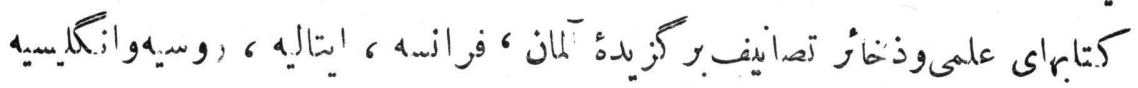

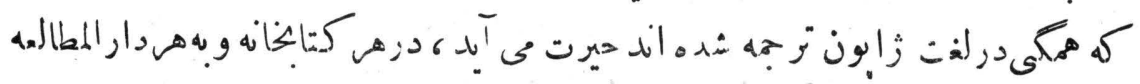

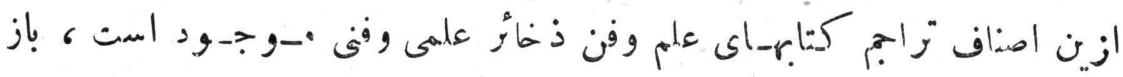

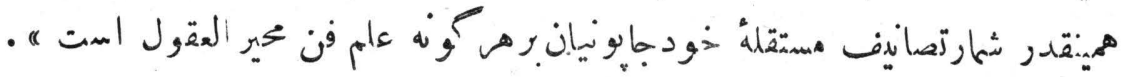

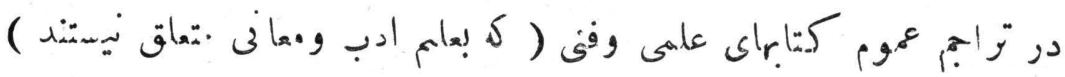

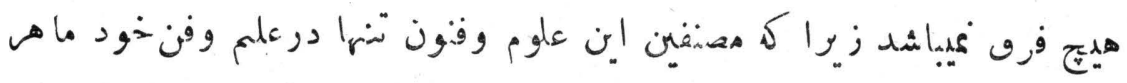

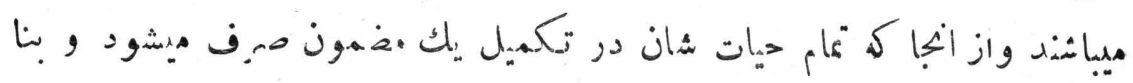

\section{(11) Sabteki (19) Coral Diakeleman}

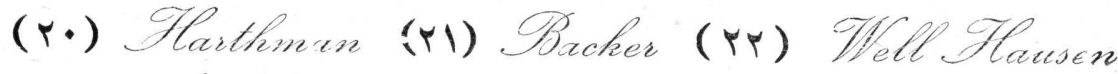
$(>)$ Siatic Sucity in Cermany. 


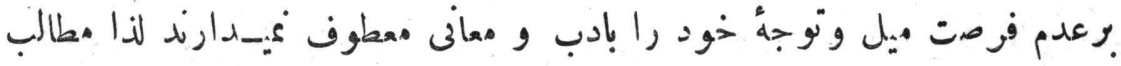

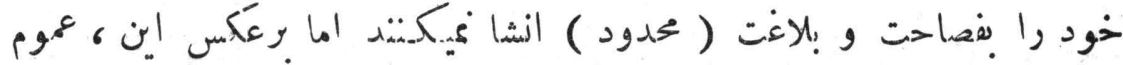

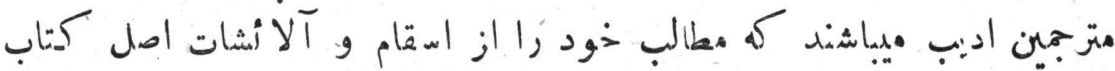

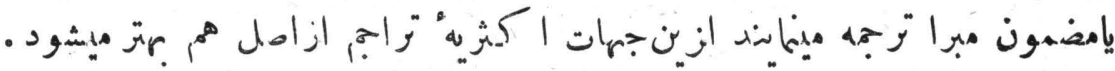

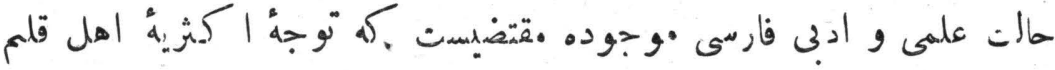

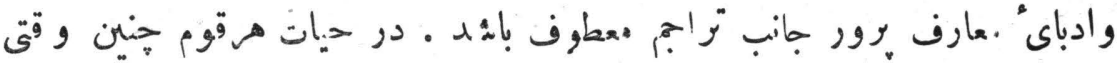

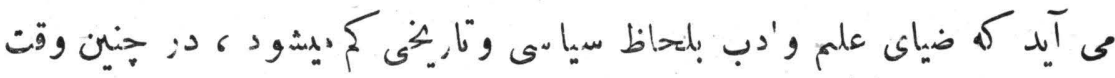

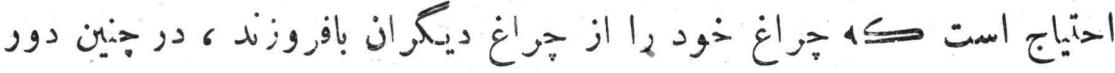

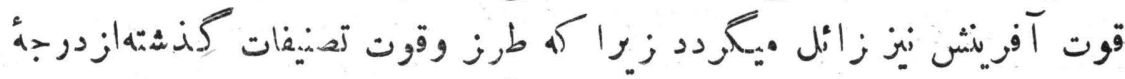

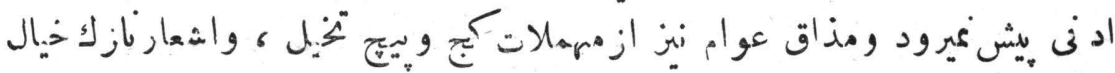

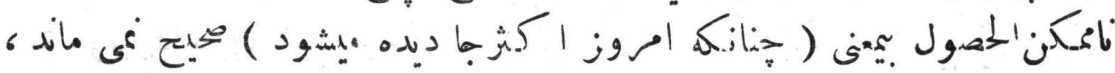

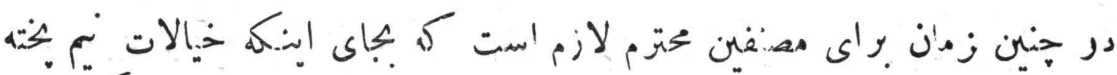

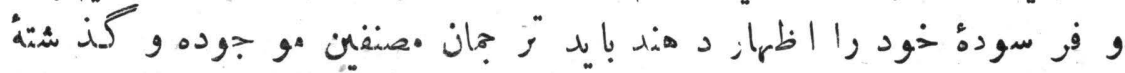

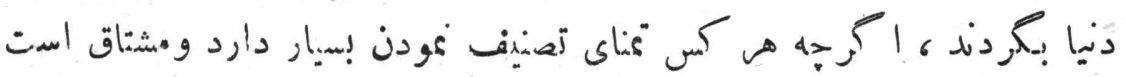

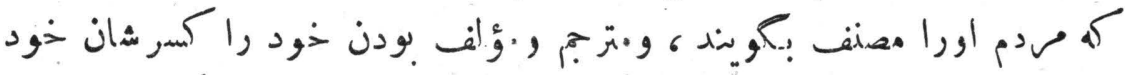

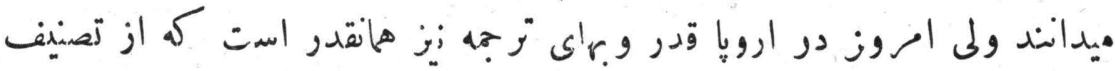

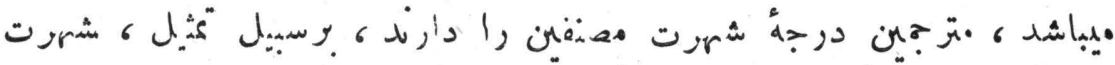

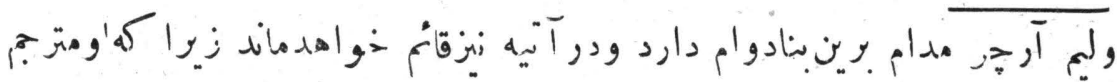

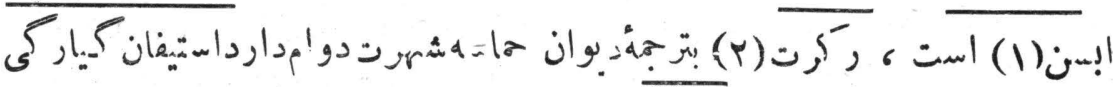

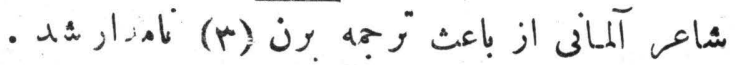

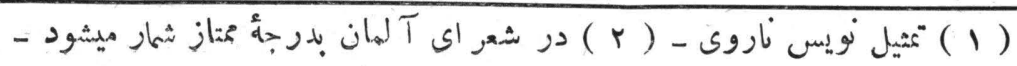

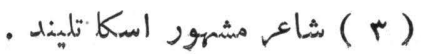


صفحة (

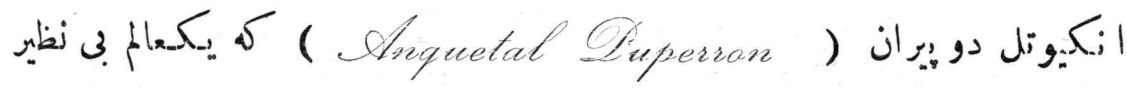

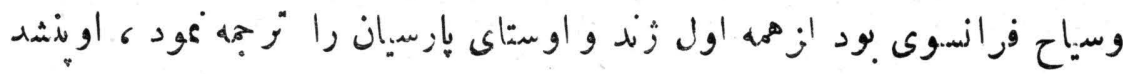

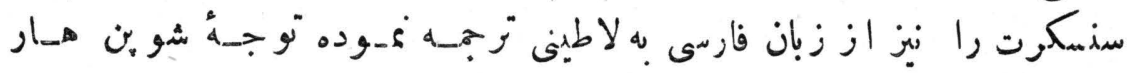

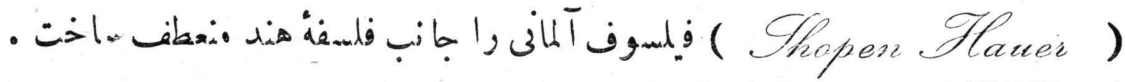

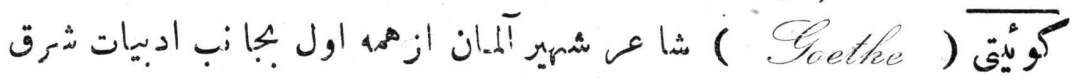

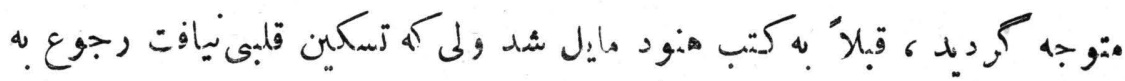

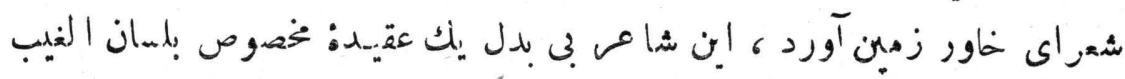

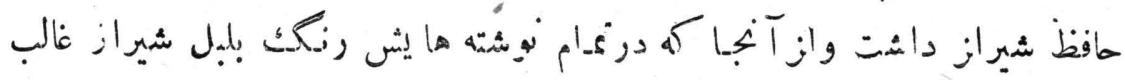

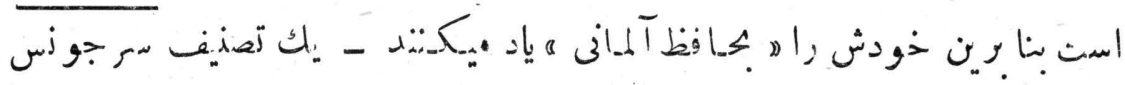

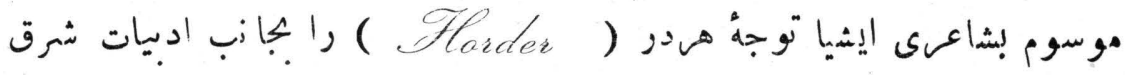

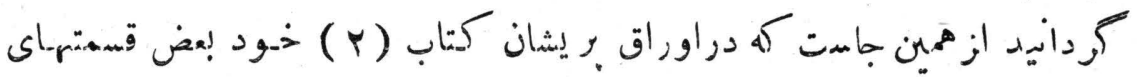

$$
\text { . }
$$

شيلى (Schellec

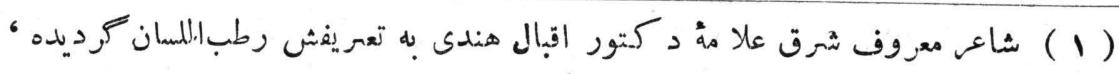

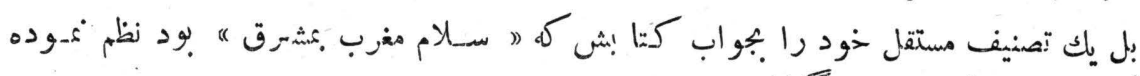

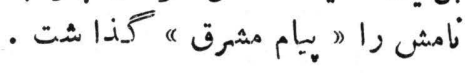

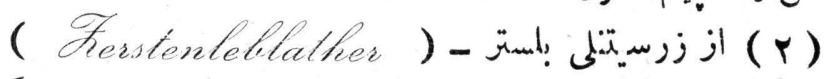

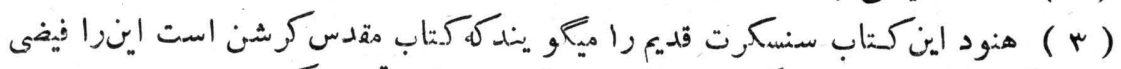

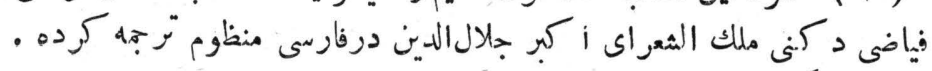

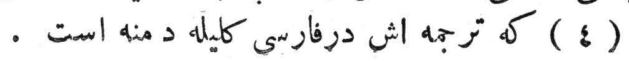




$$
\text { كرديد استفاده وشهرت بسيار هاصل نعود . }
$$

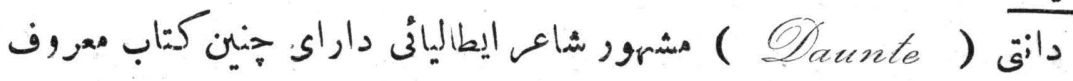

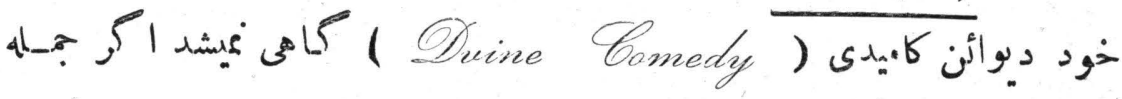

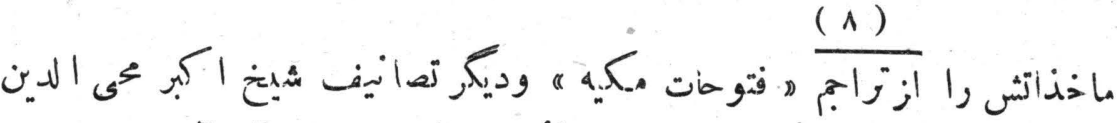

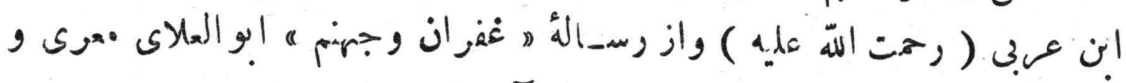

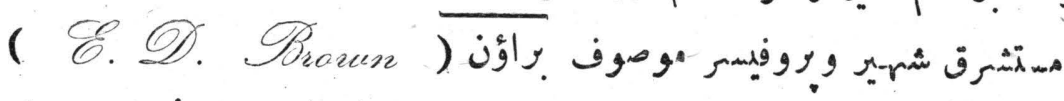

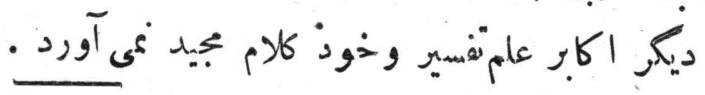

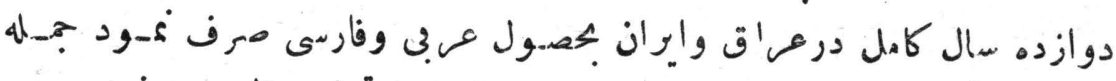

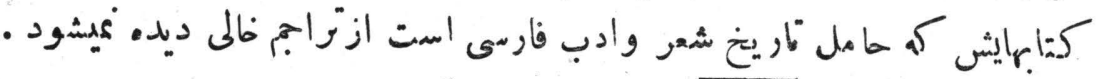

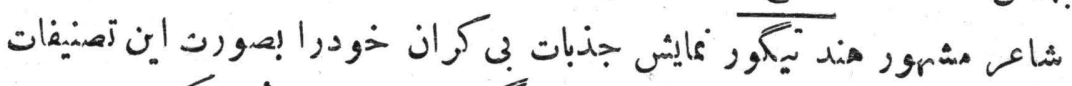

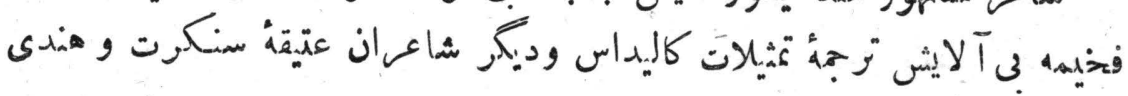

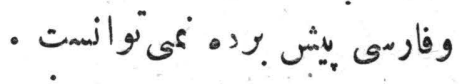

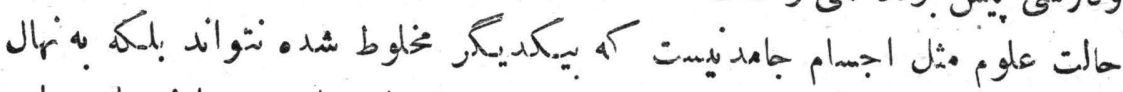

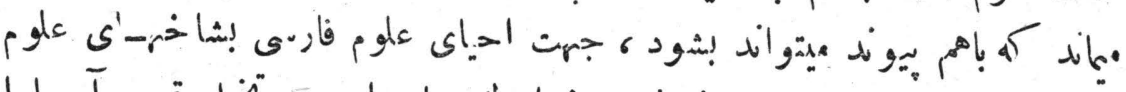

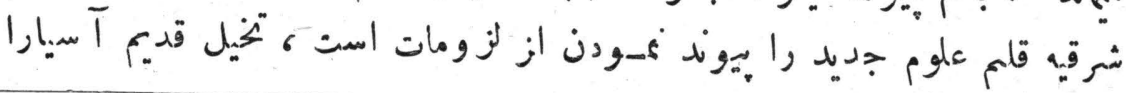

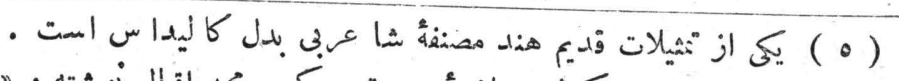

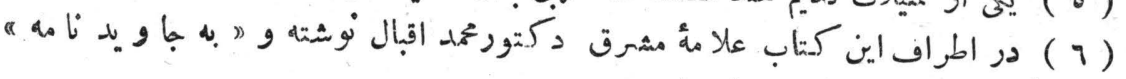

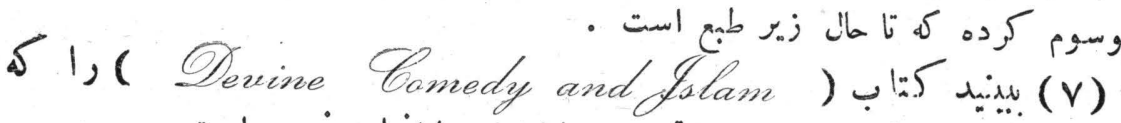

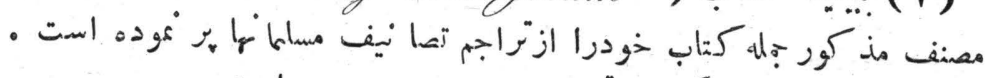

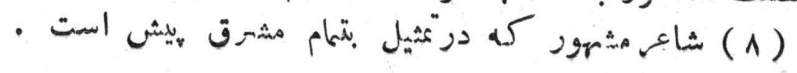




\section{مال الول - مجلة كابل}

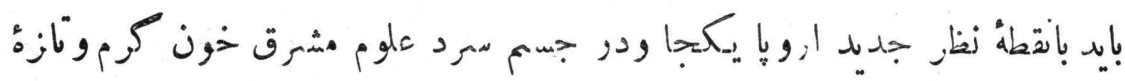

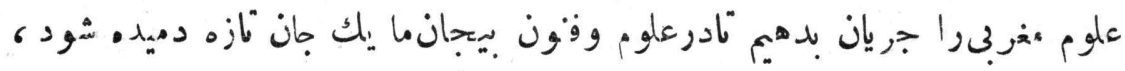

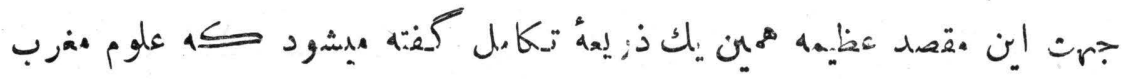

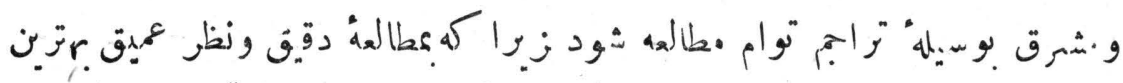

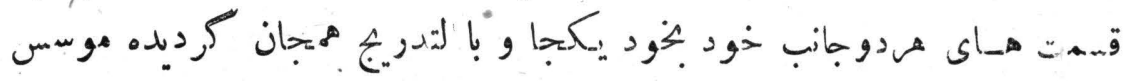

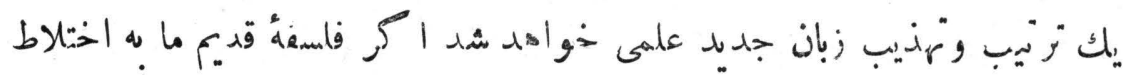

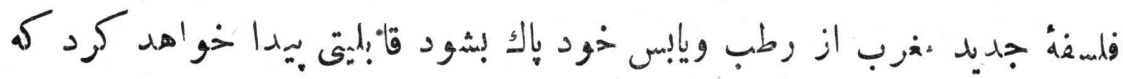

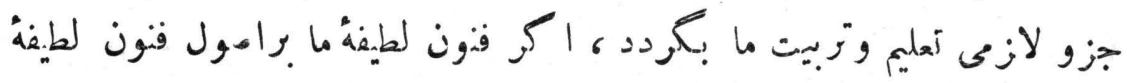

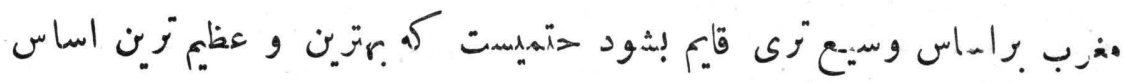

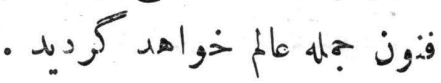

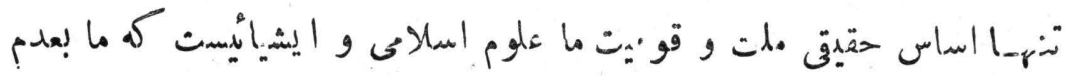

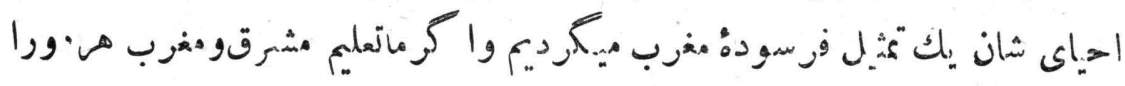

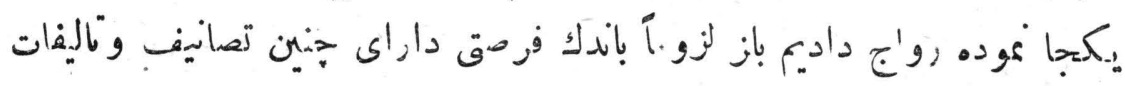

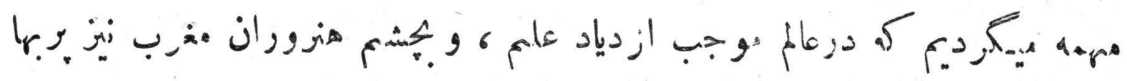

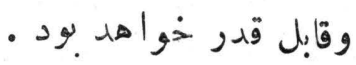

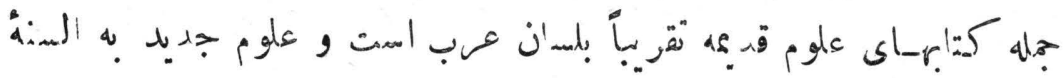

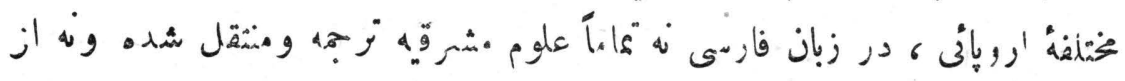

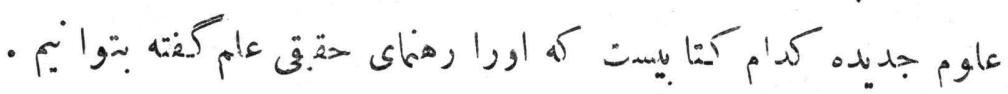

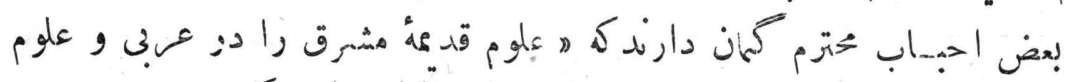

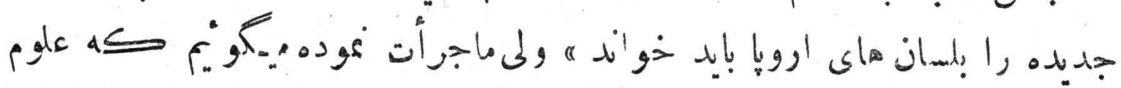

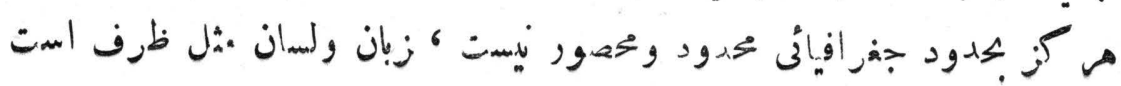




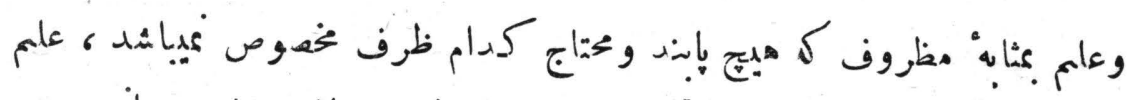

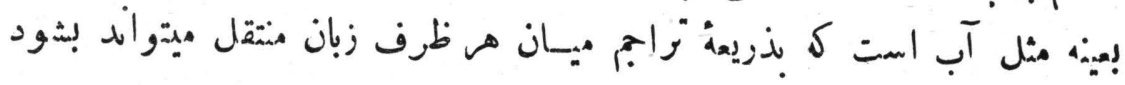

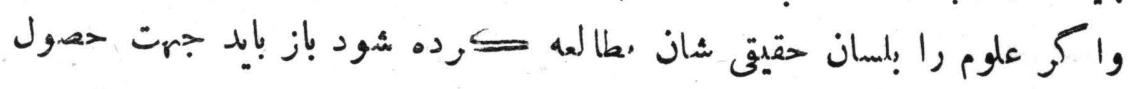

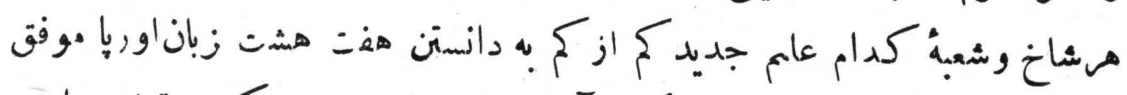

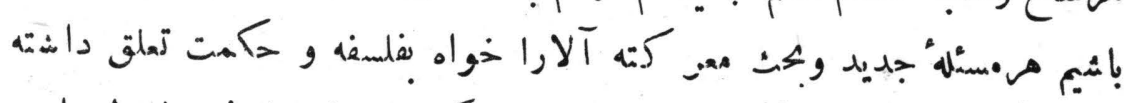

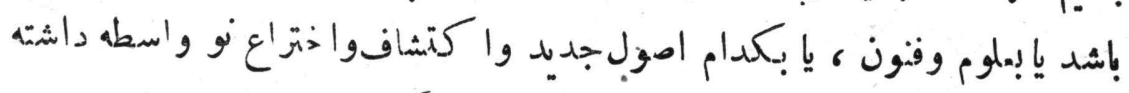

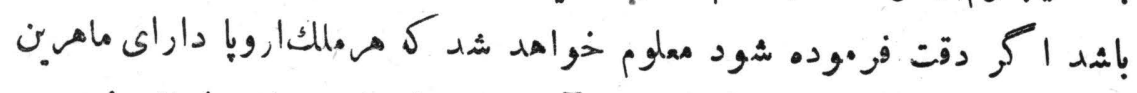

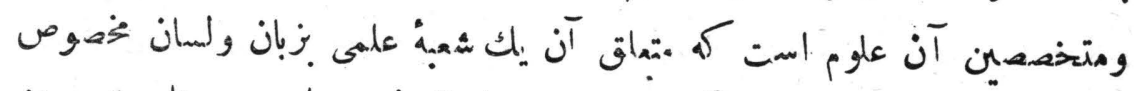

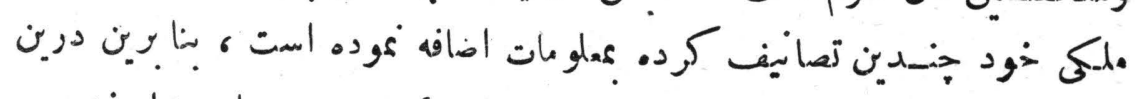

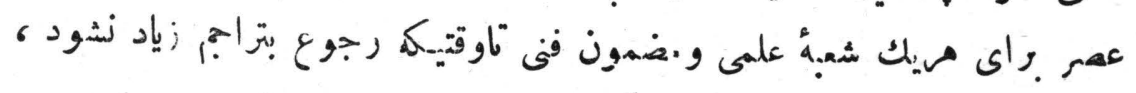

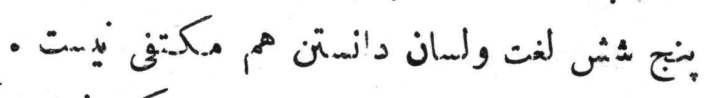

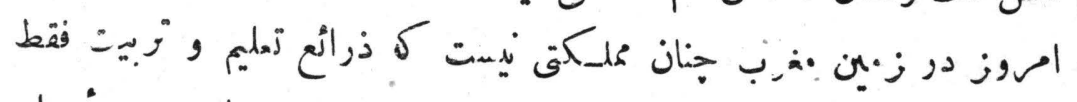

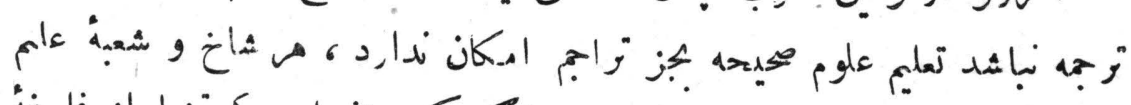

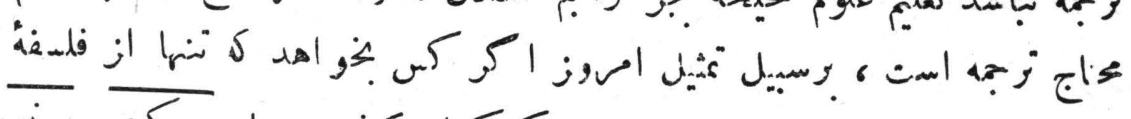

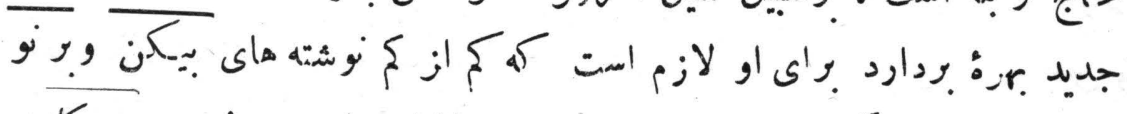

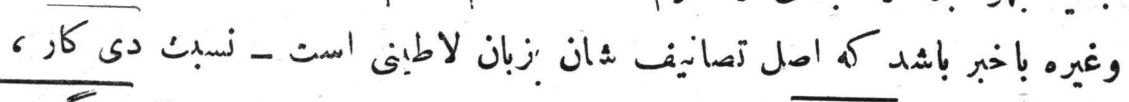

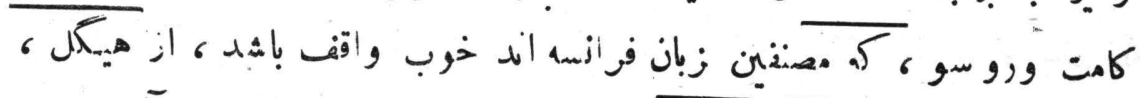

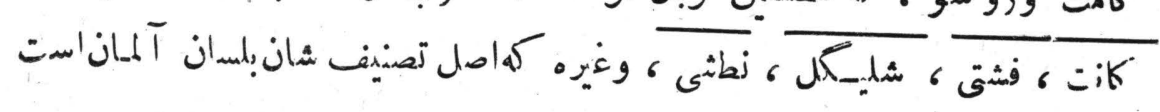

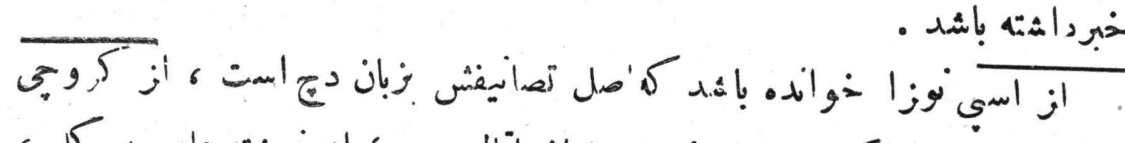

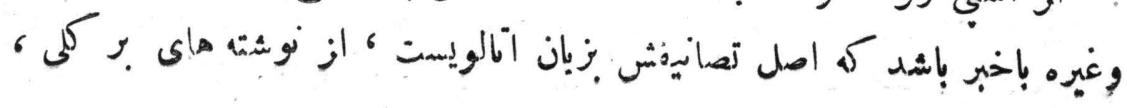


( 2 (

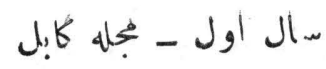

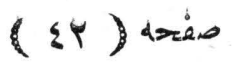

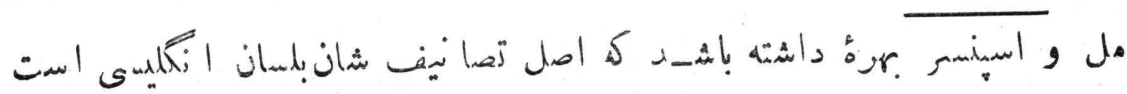

و قس على هذا ا.

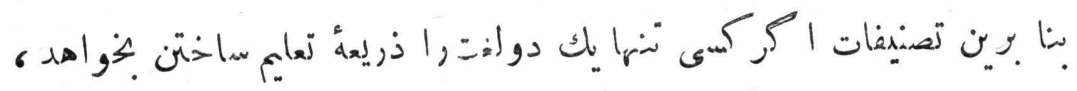

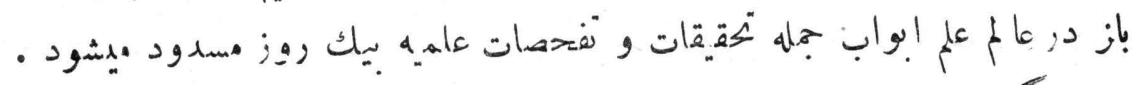

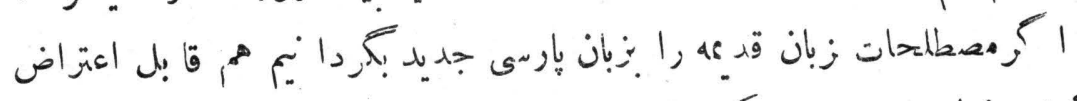

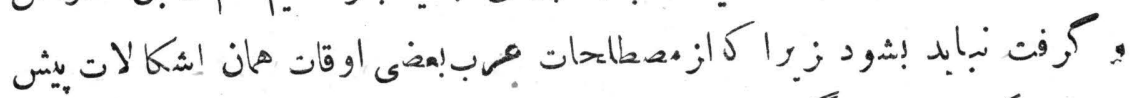

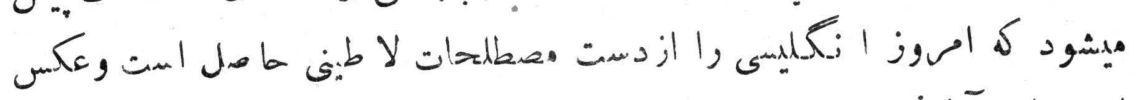

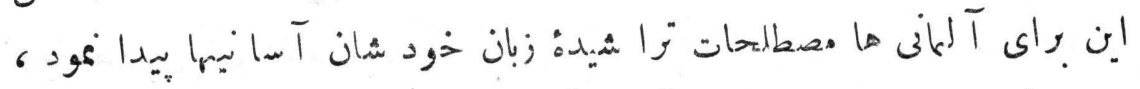

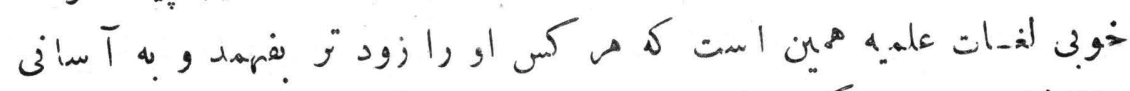

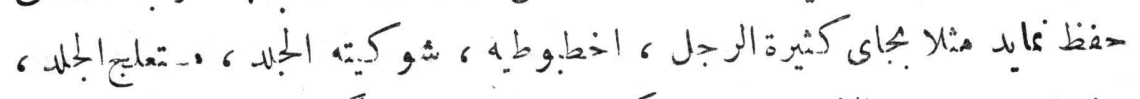

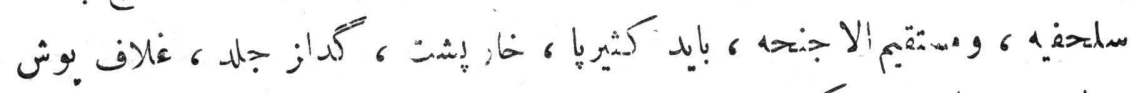

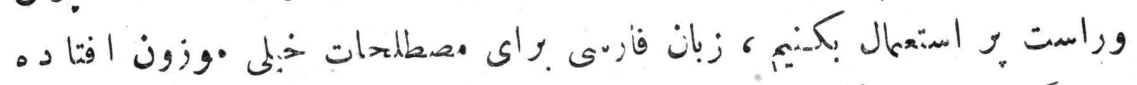

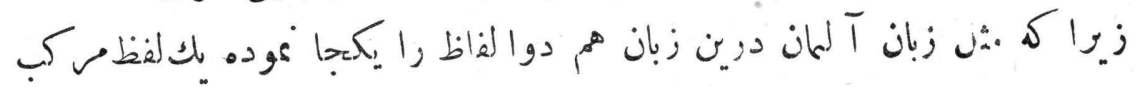

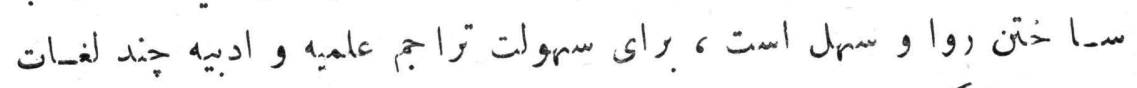

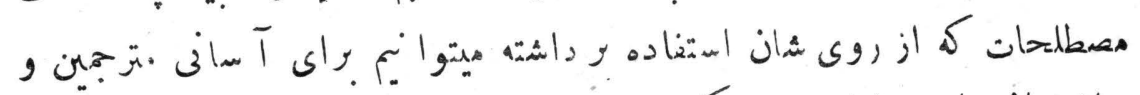

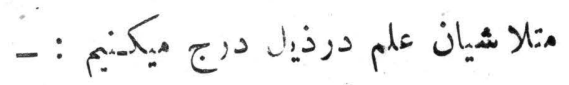

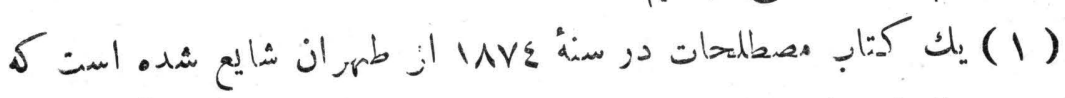

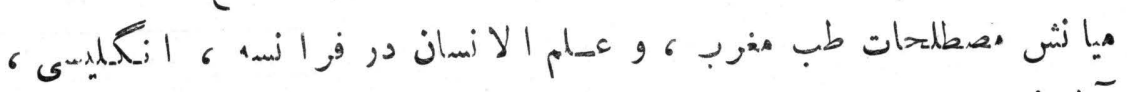

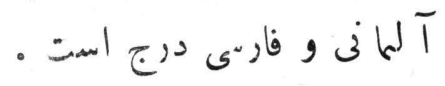

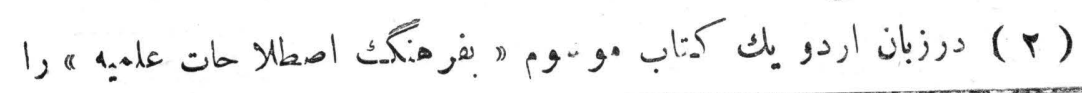
(1) 


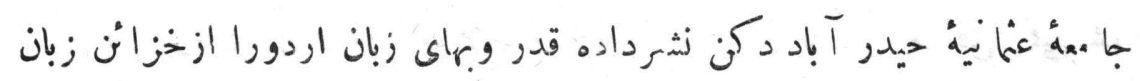

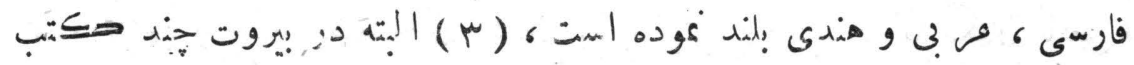

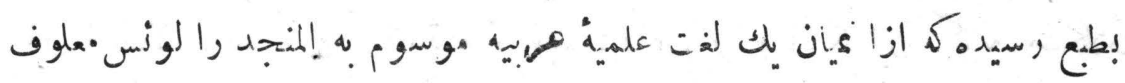

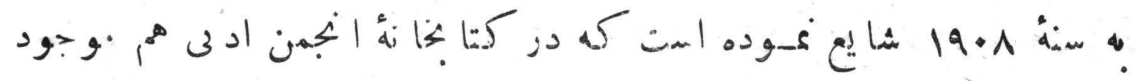

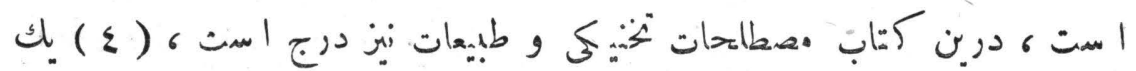

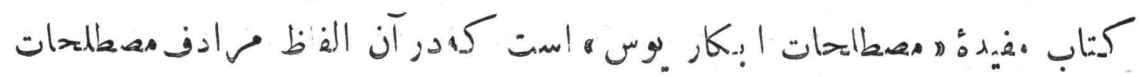

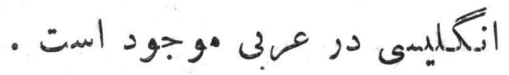

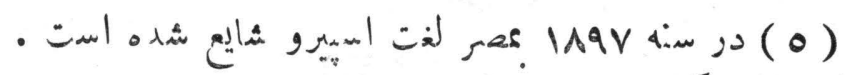

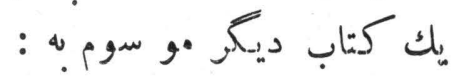

\section{(1) Dictionary of the Technical Temesused in the-

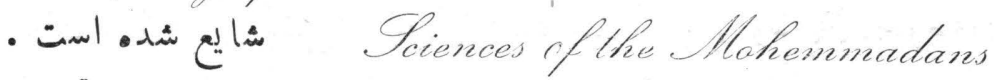

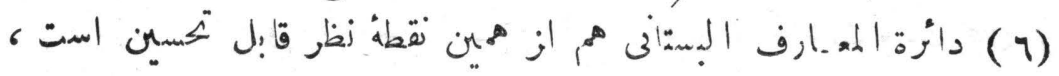

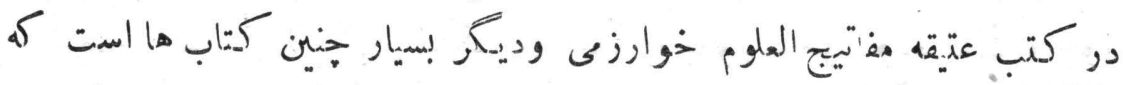

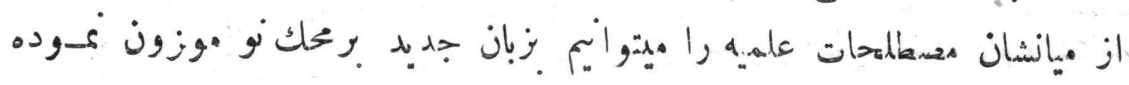

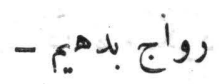

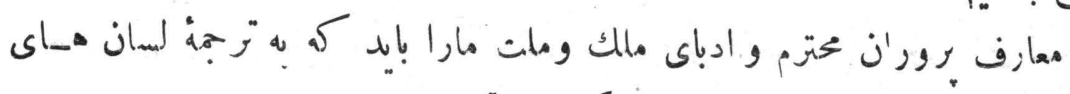

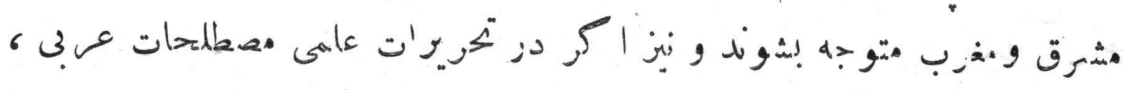

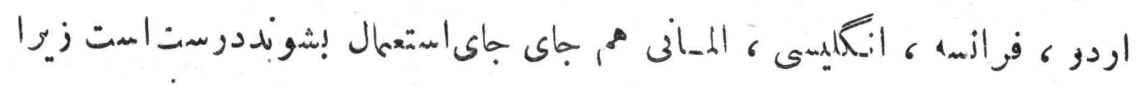

از

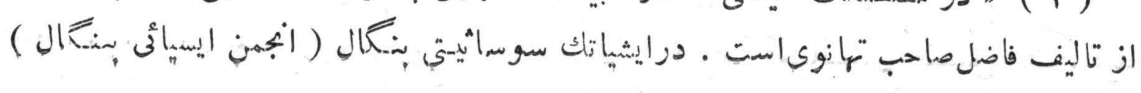

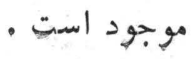


سال اول - مجله" (2)

( $\{\varepsilon$ ( ) ص

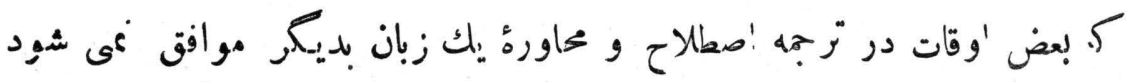

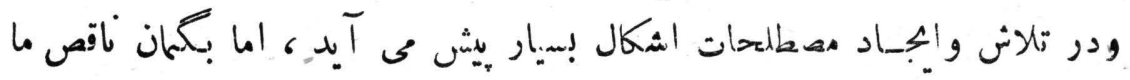

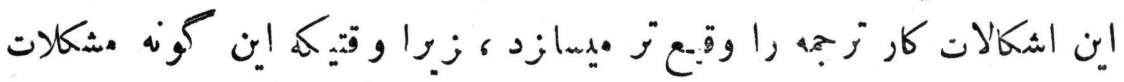

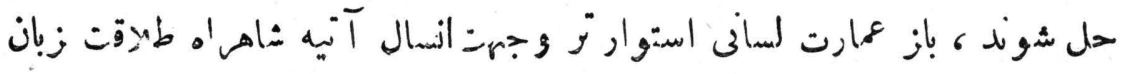

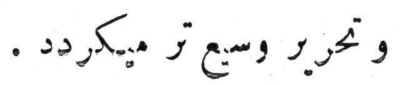

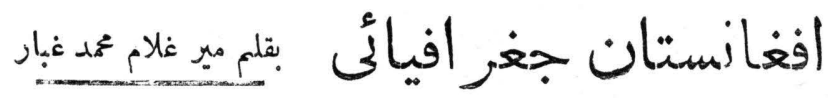
(Y)

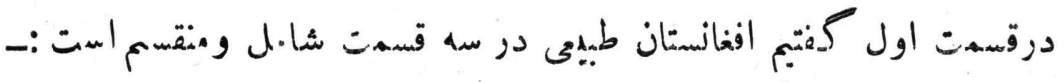

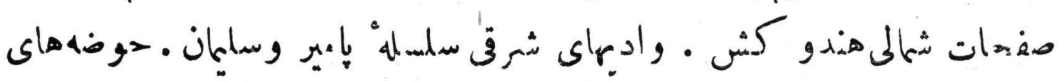

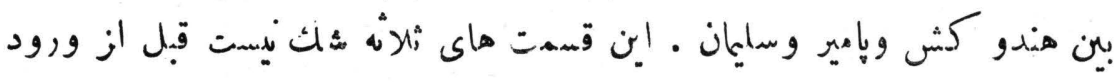

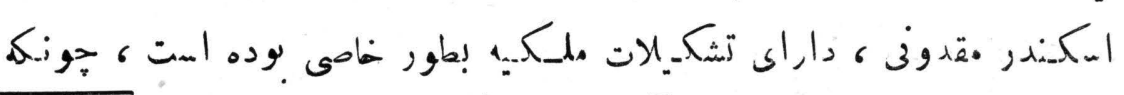

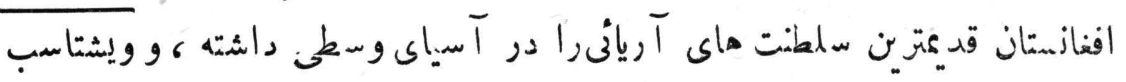

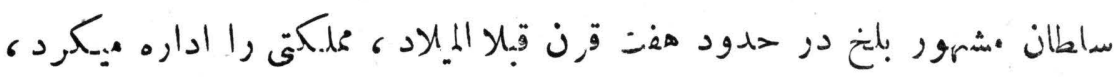

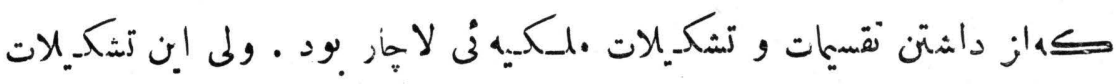

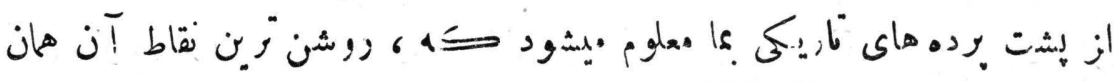

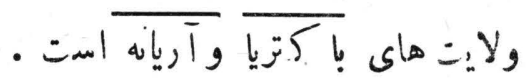

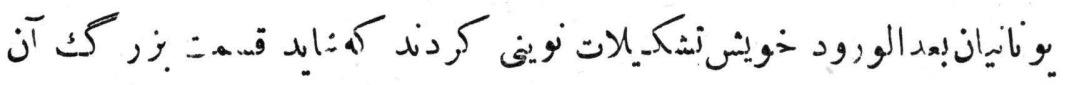

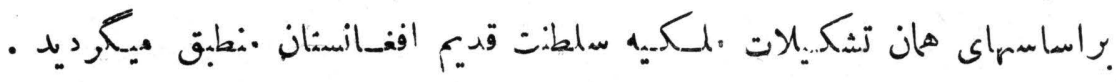

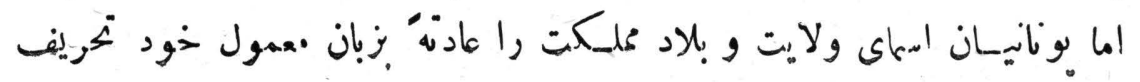


(z) $:$ )

سال اول ـ مجلة كال

(ะ0) (2)

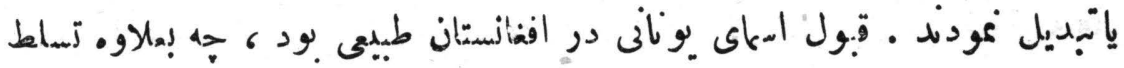

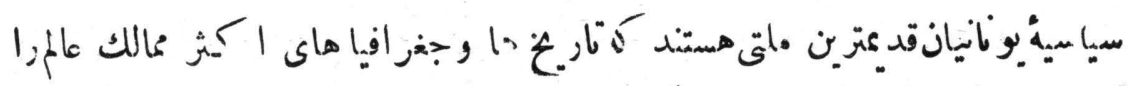

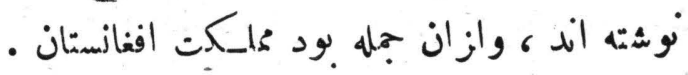

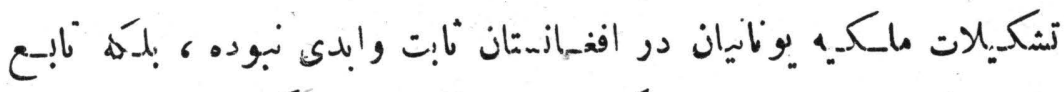

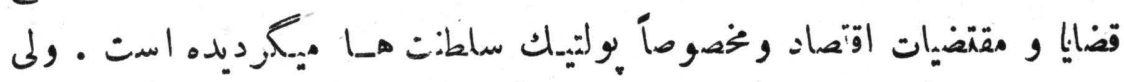

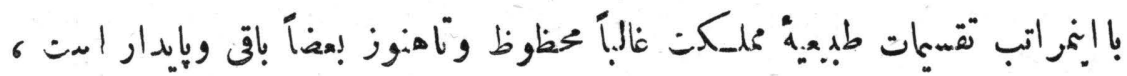

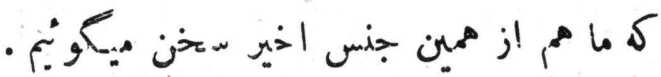

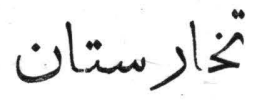

إعنى قُطغن وبدخشان

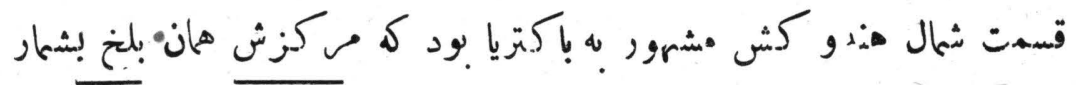

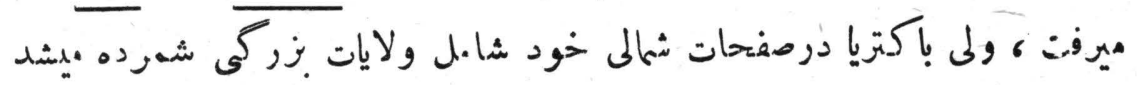

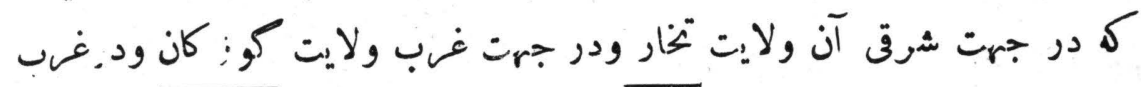
كوز كان ولايت مركيانا اوفتاده بود .

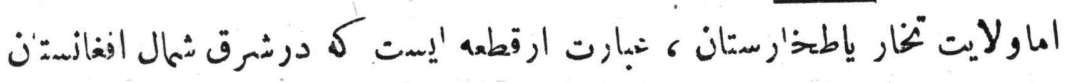

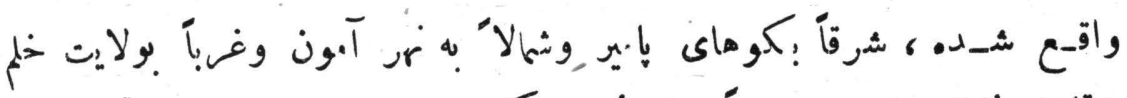

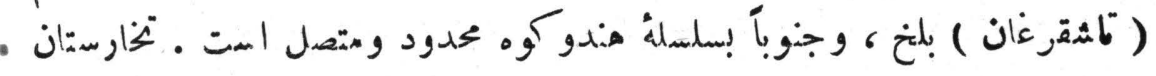

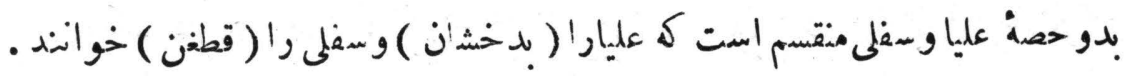

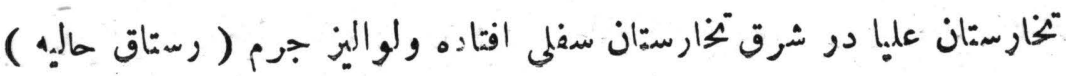


سال اول - مجله كابل

(24) isia

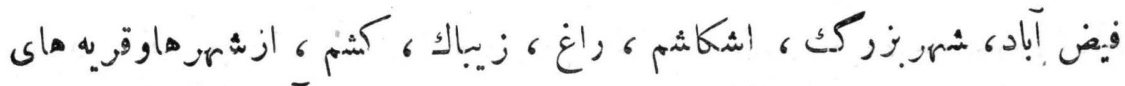

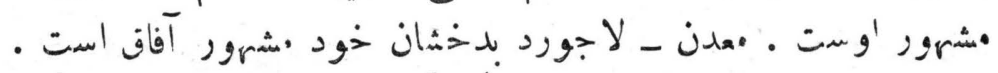

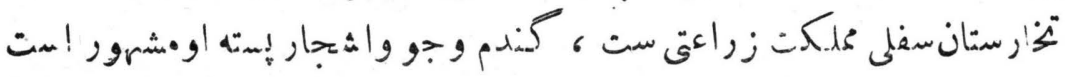

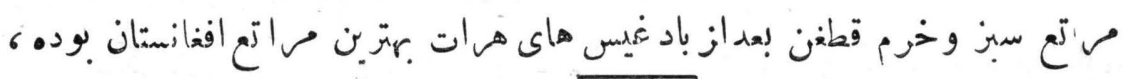

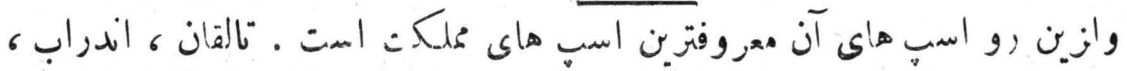

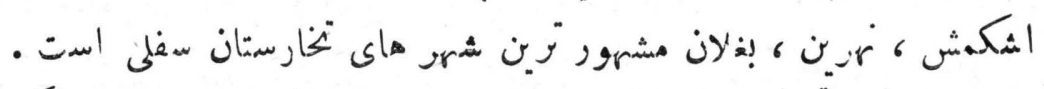

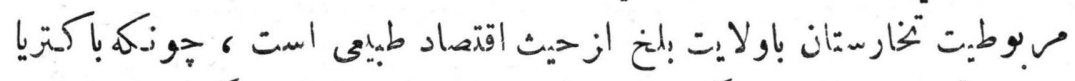

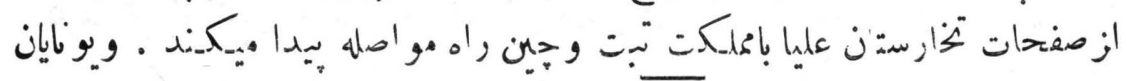

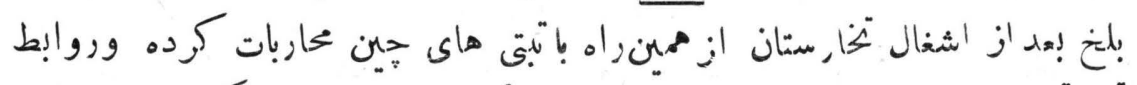

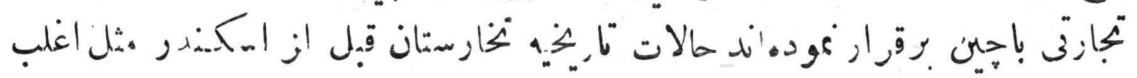

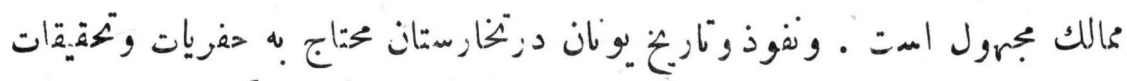

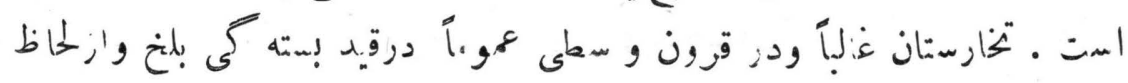

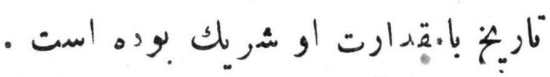

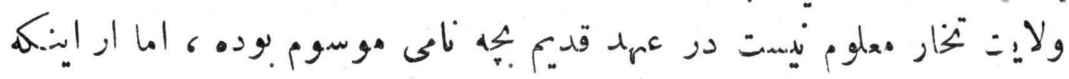

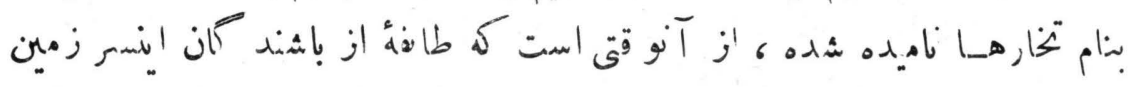

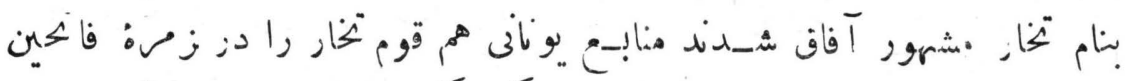

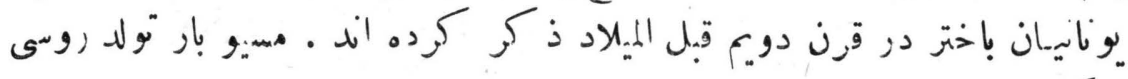

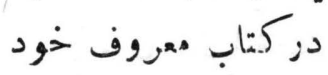

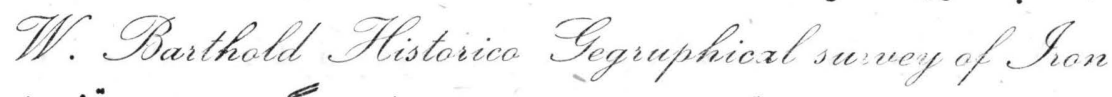

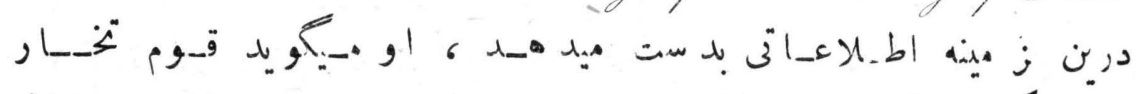

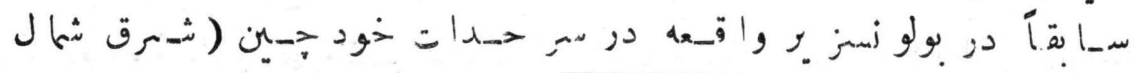

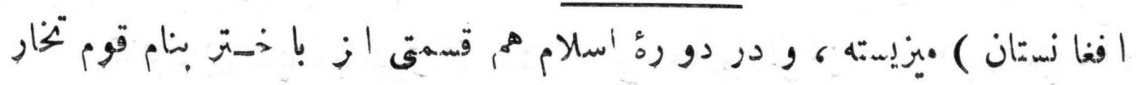




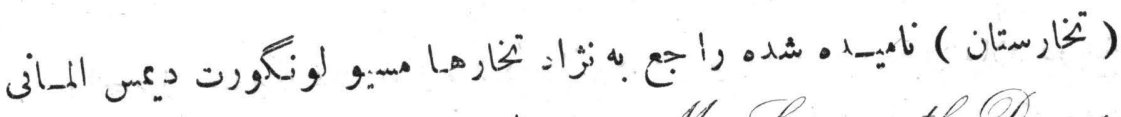
No. Sanguarth Oomed

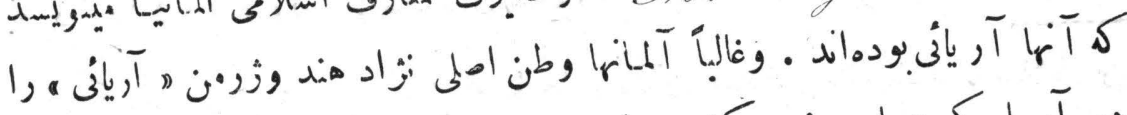

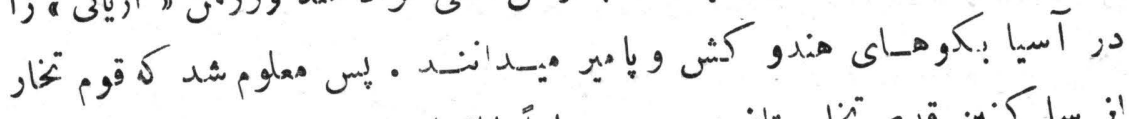

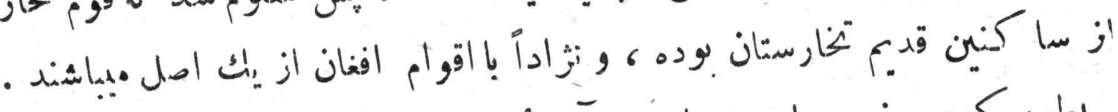

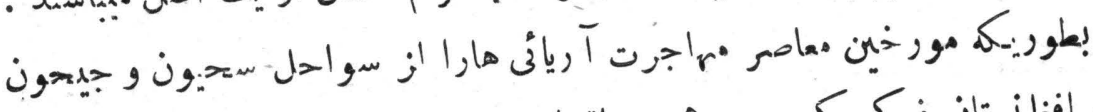

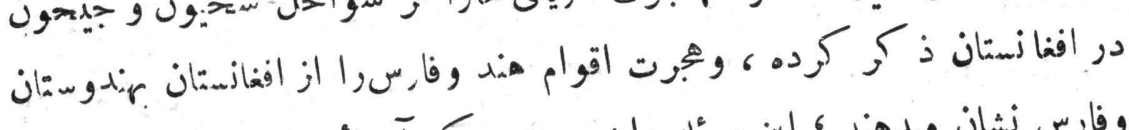

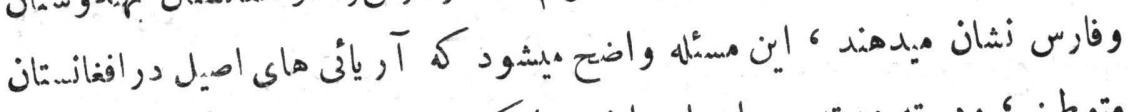

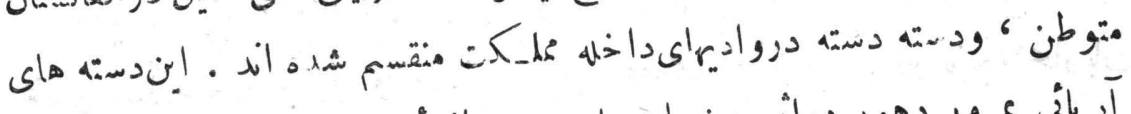

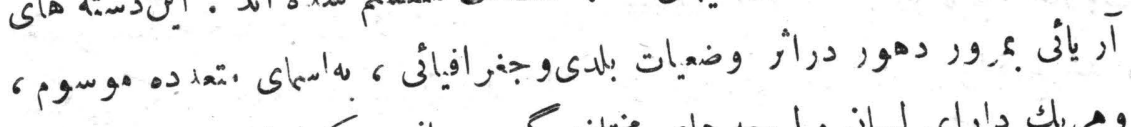

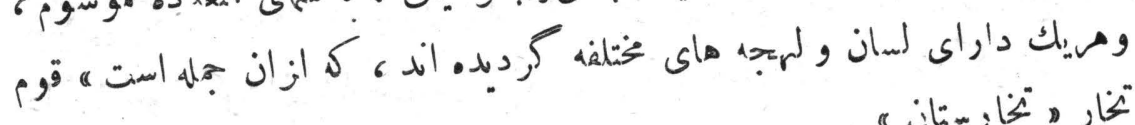

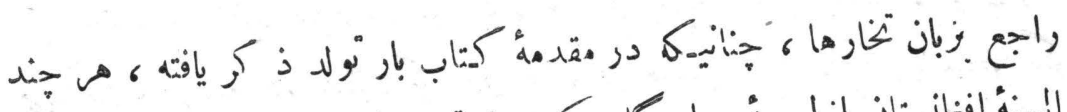

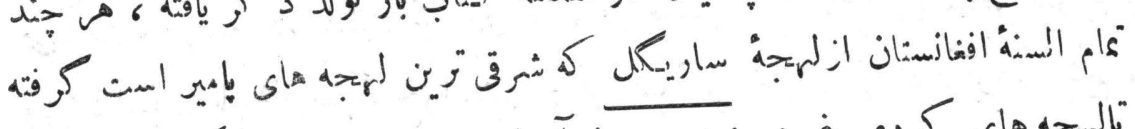

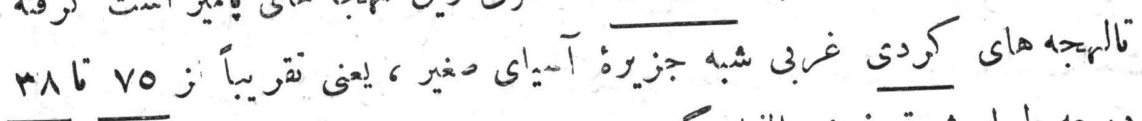

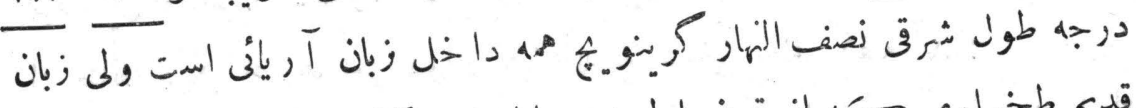

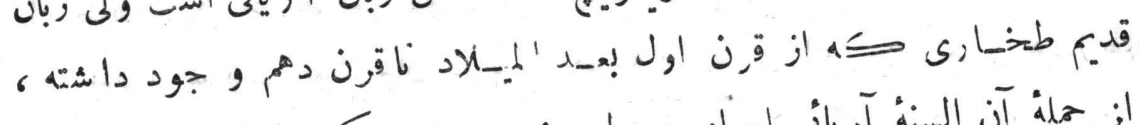

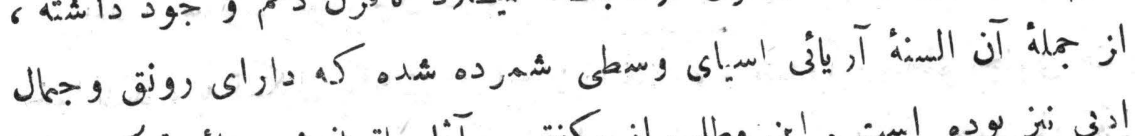

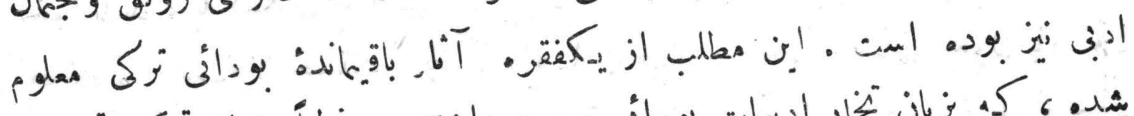

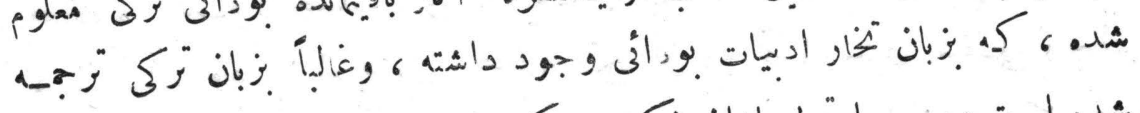

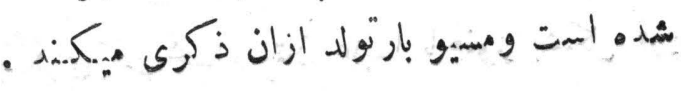




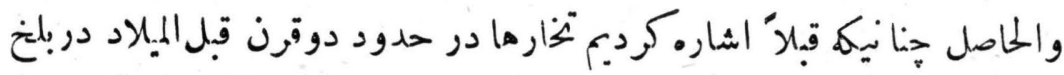

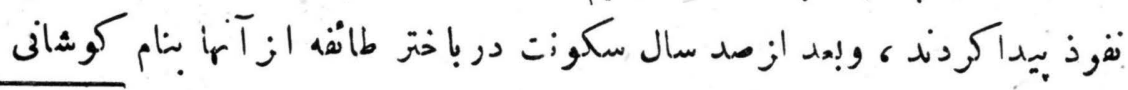

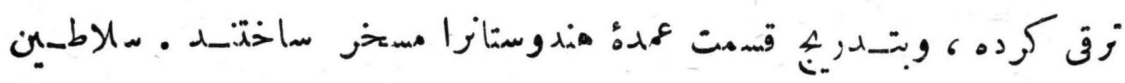

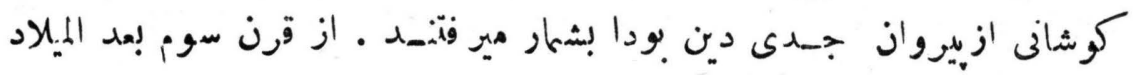

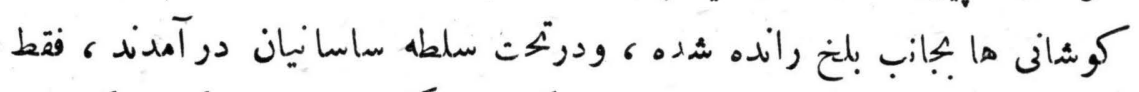

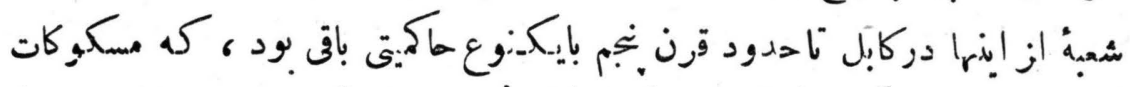

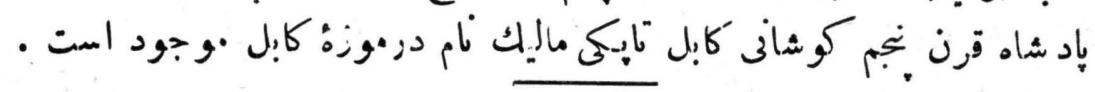

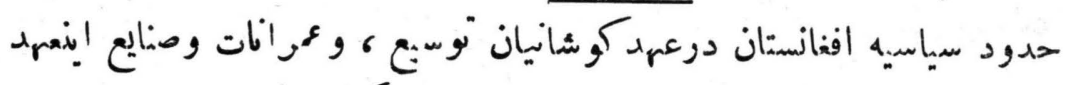

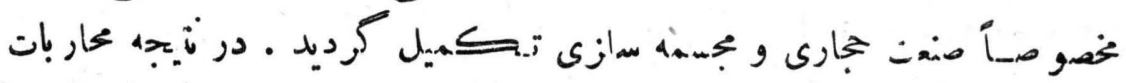

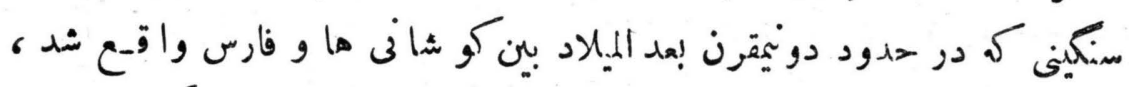

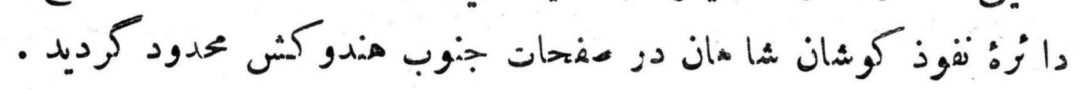

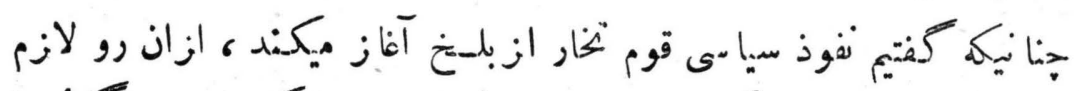

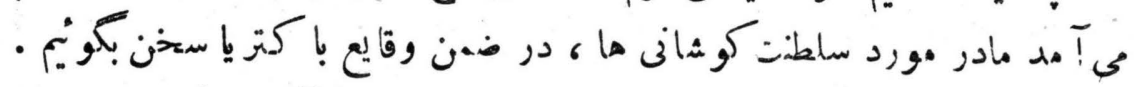

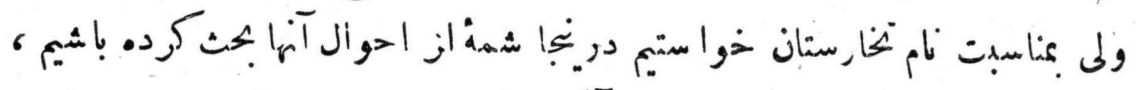

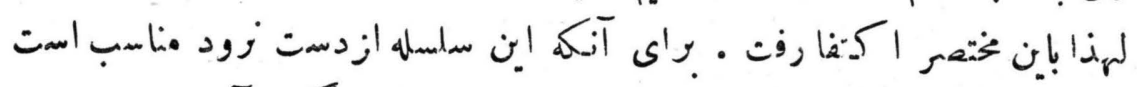

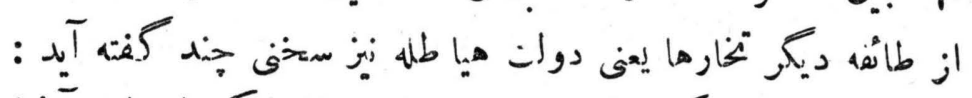

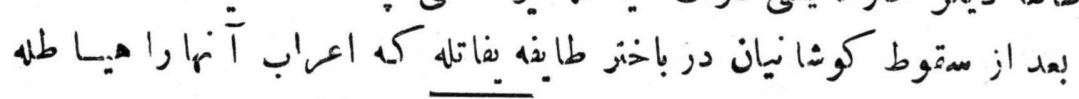

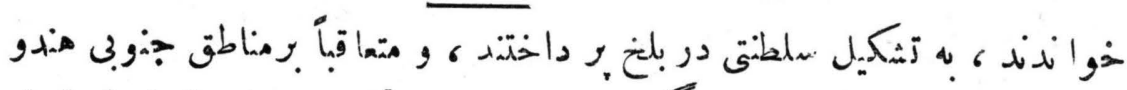

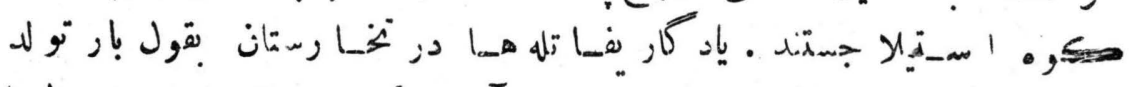

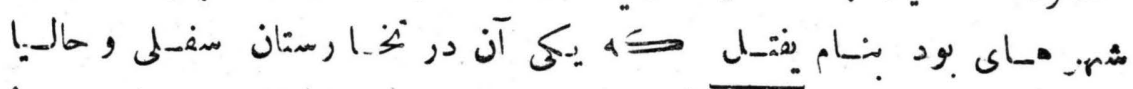

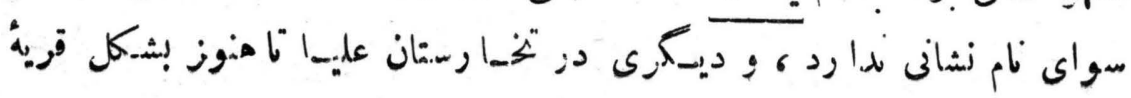




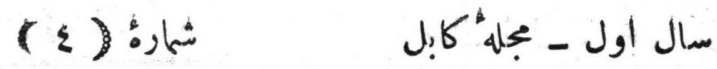

( (29) drib

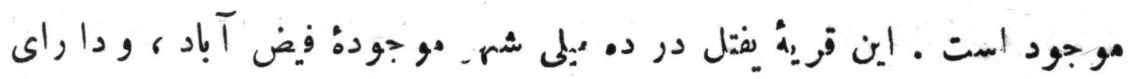

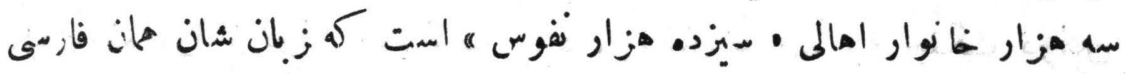

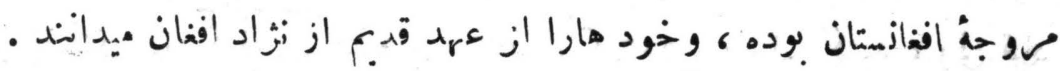

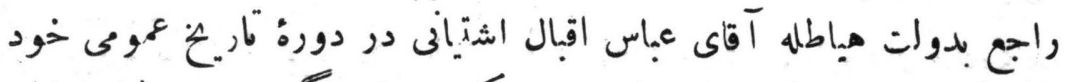

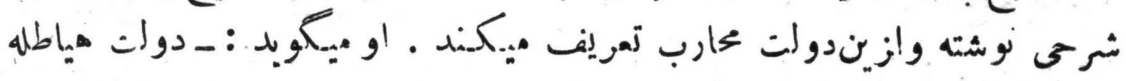

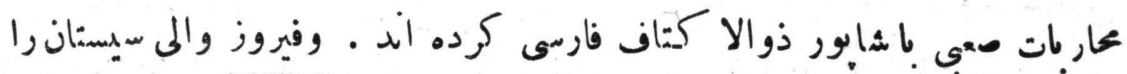

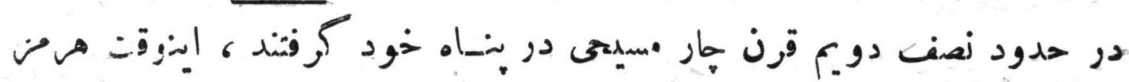

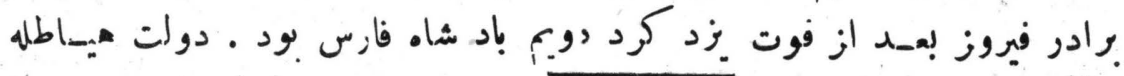

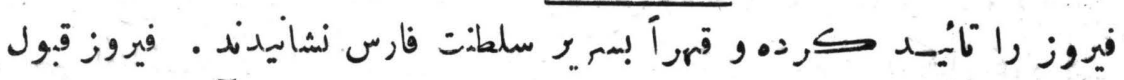

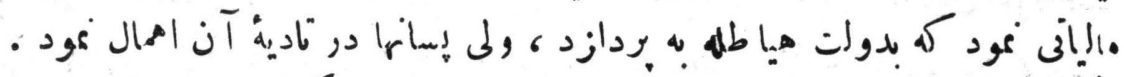

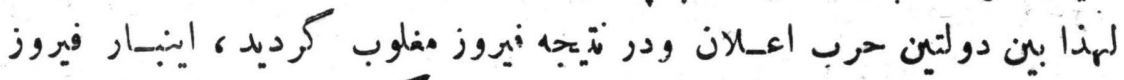

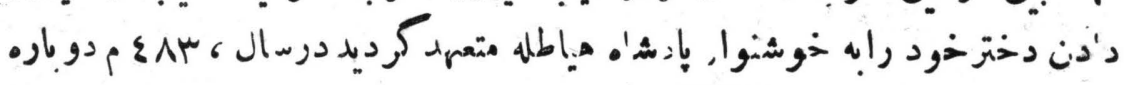

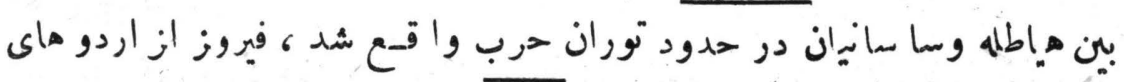

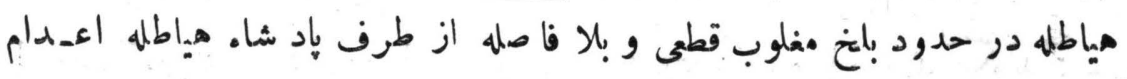
كرديد.

بلاش بعد از فيروز باد شاه فارس شد ( (

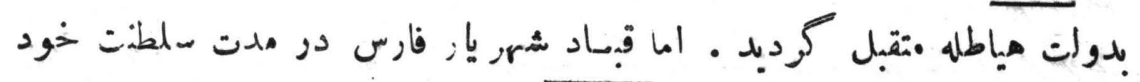

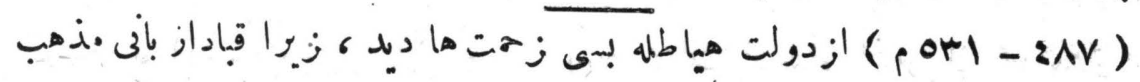

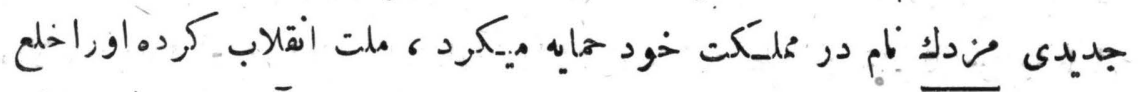

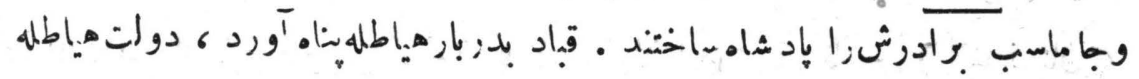

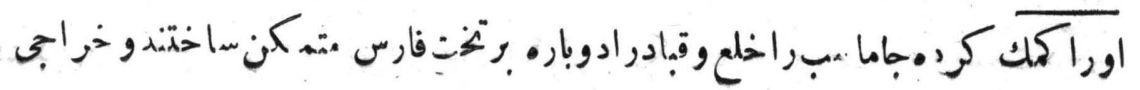




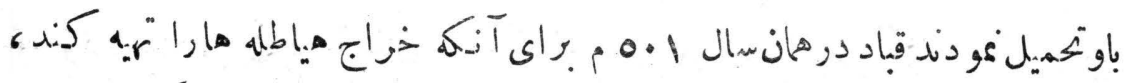

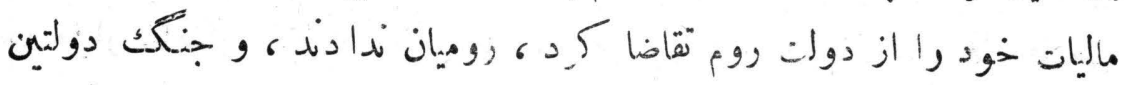

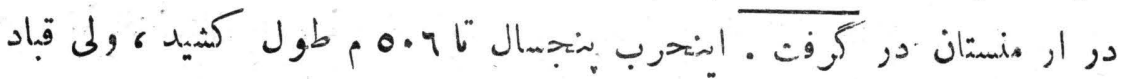

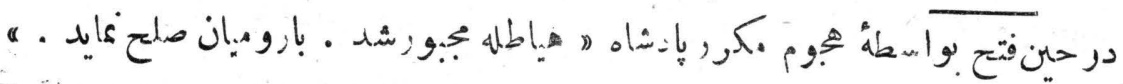

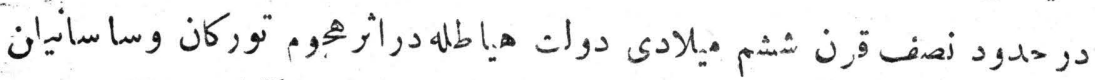

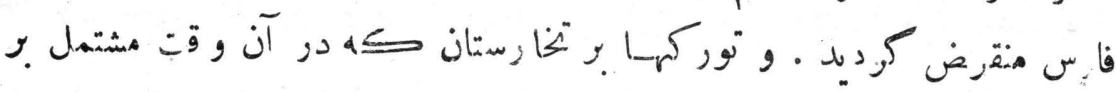

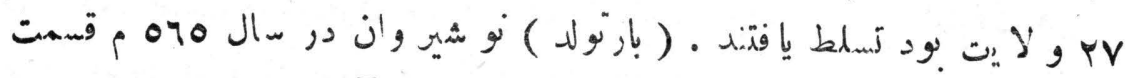

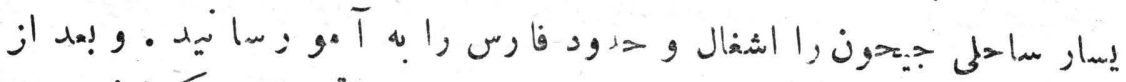

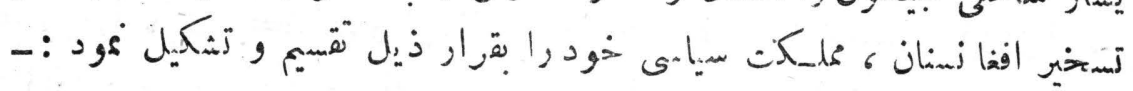

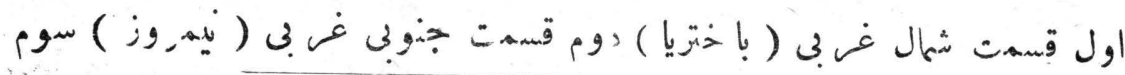

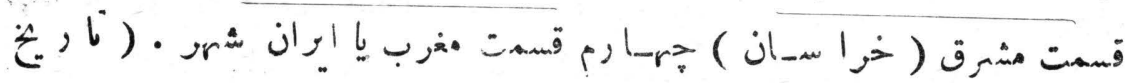

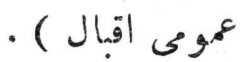

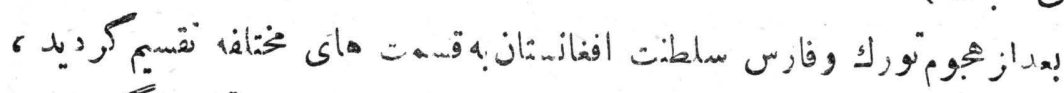

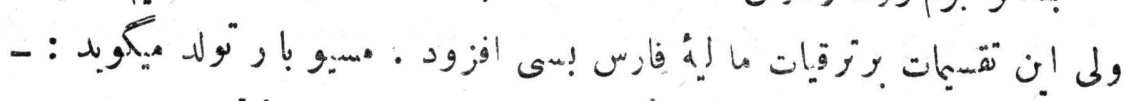

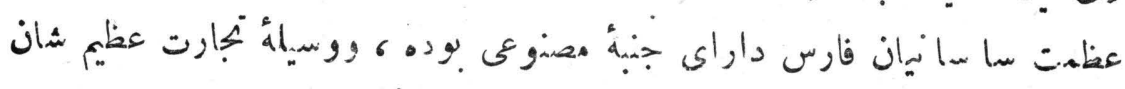

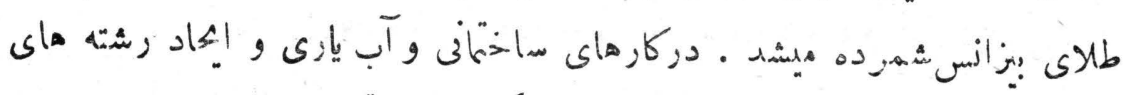

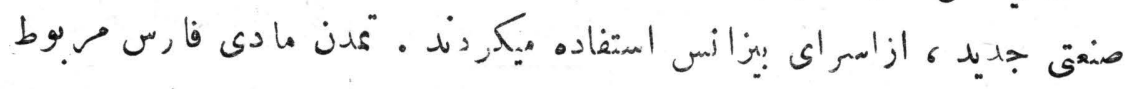

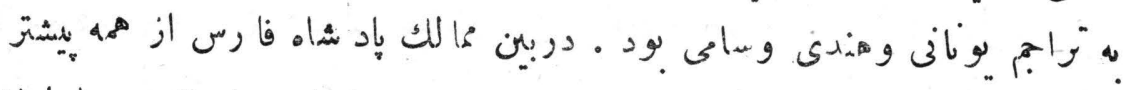

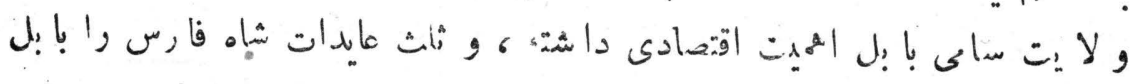

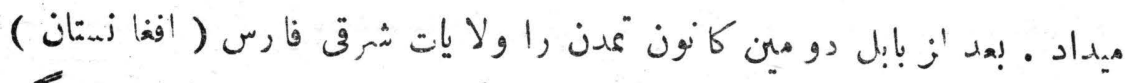

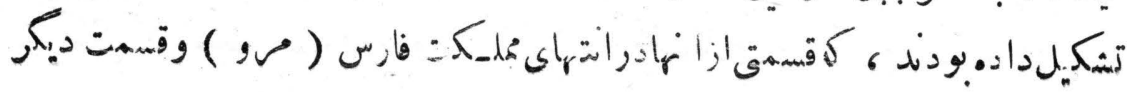




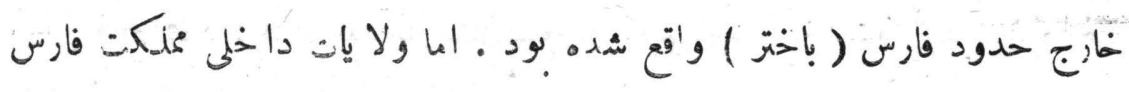

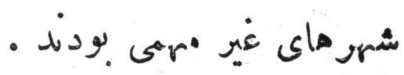

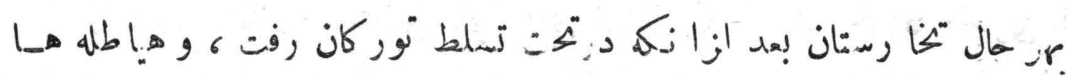

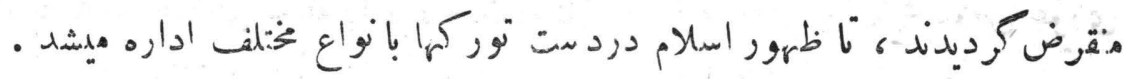

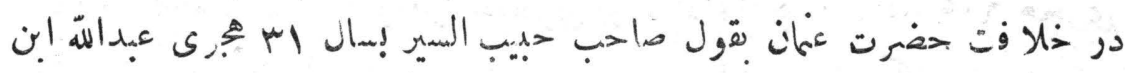

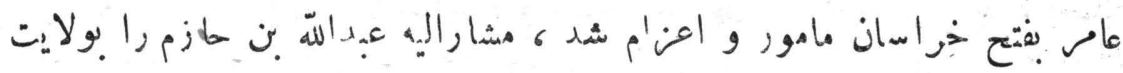

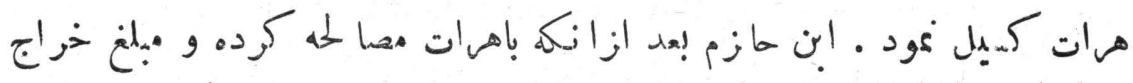

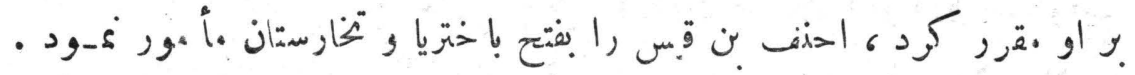

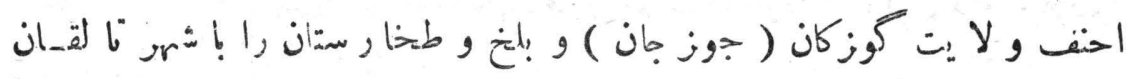

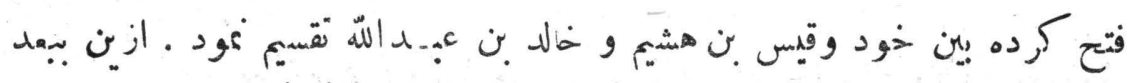

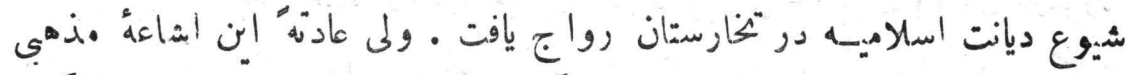

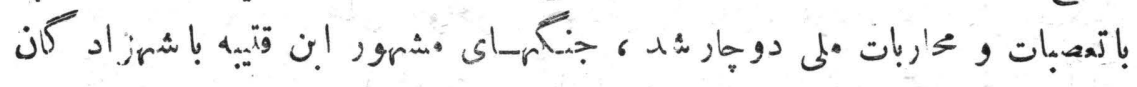

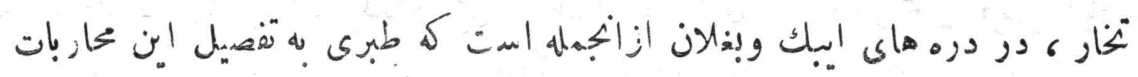

$$
\text { - : }
$$

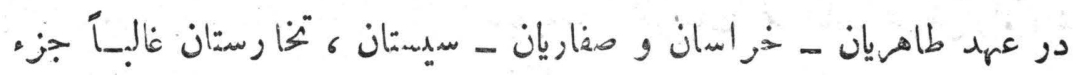

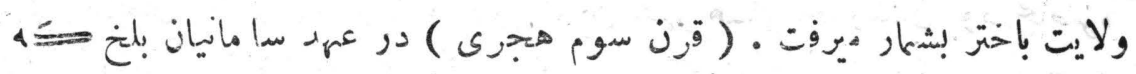

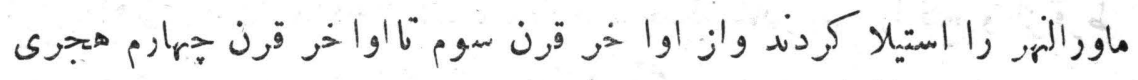

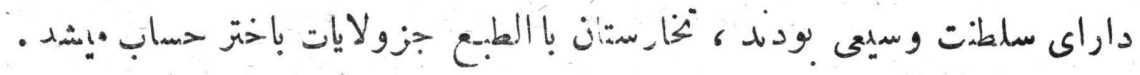

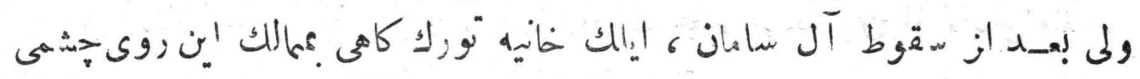

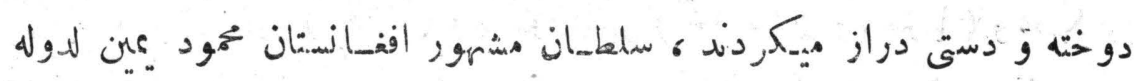

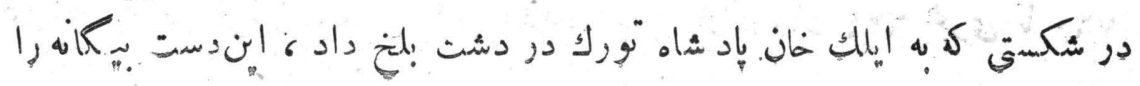




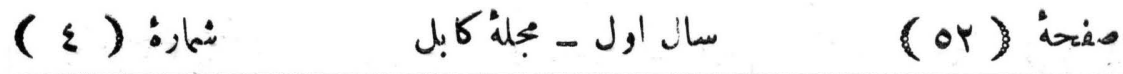

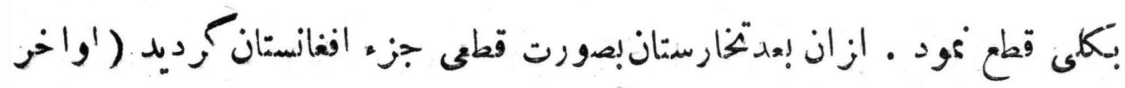

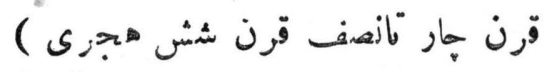

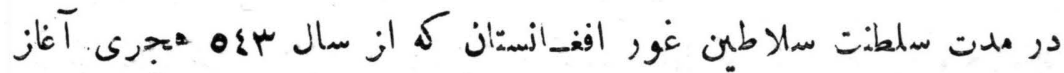

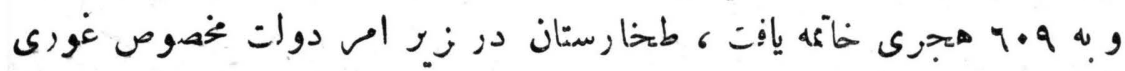

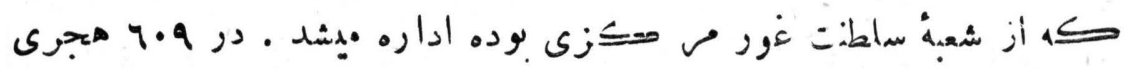

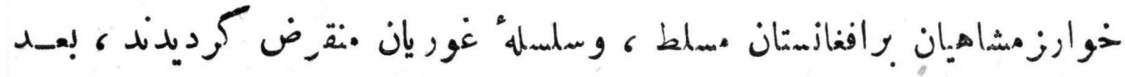

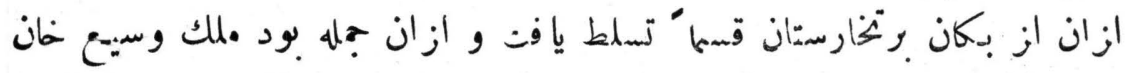

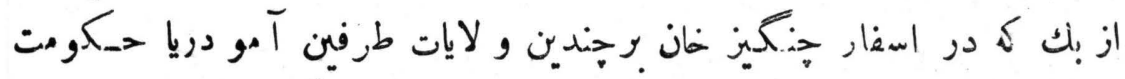

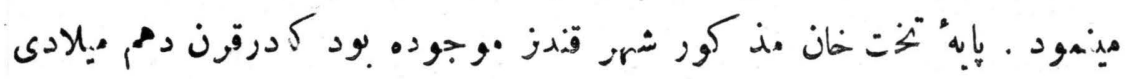

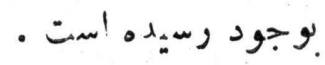

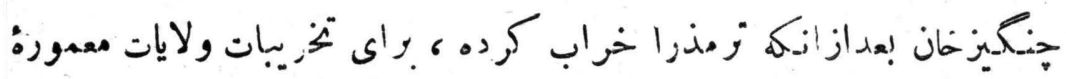

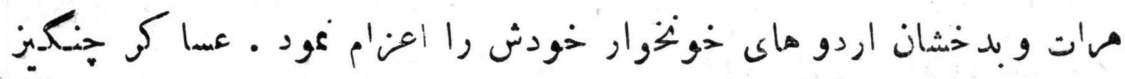

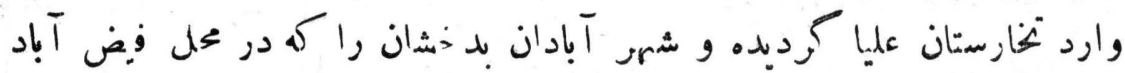

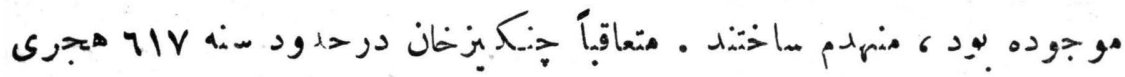

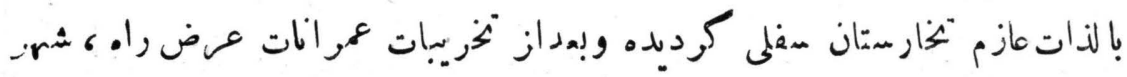

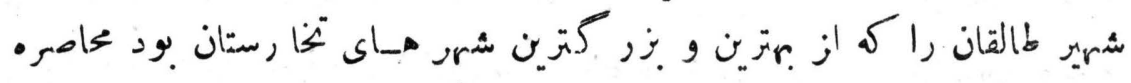

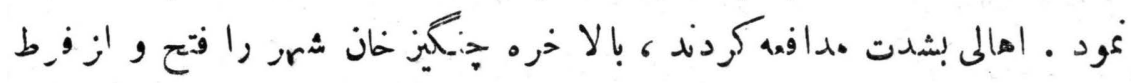

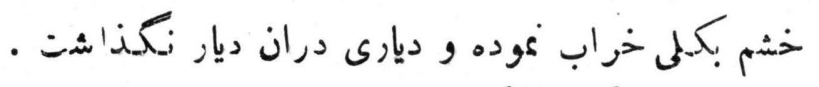

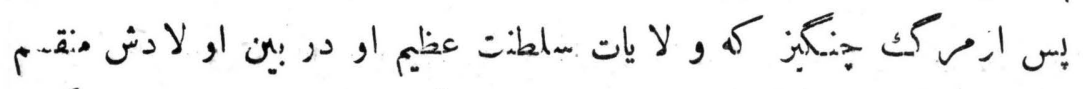

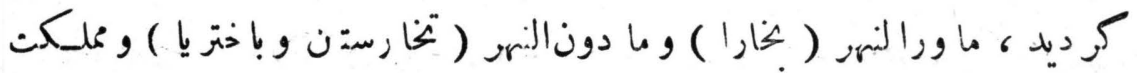

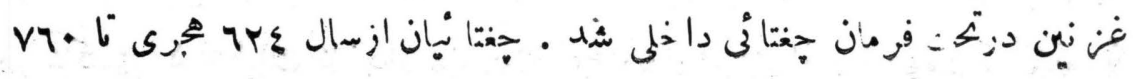




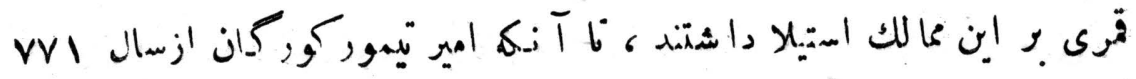

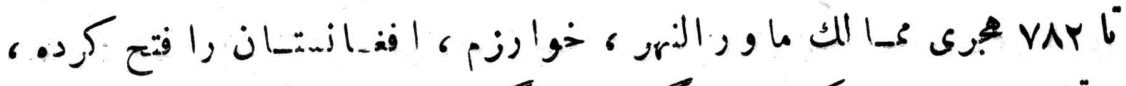

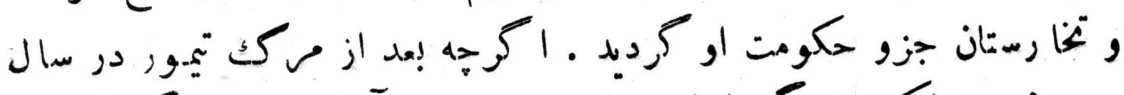

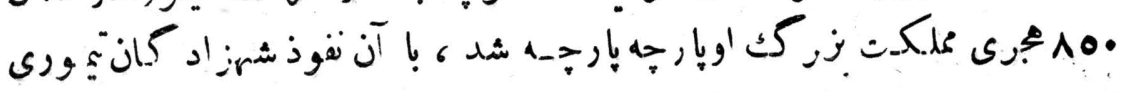

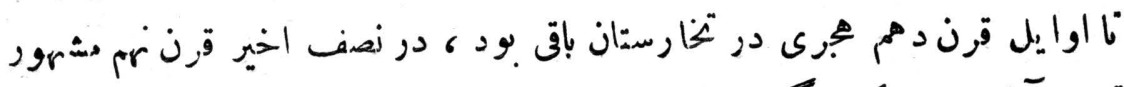

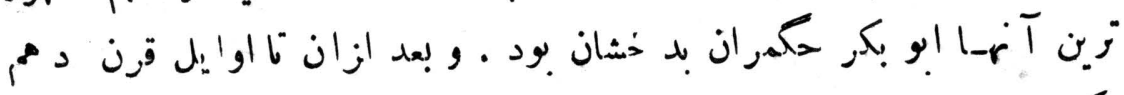

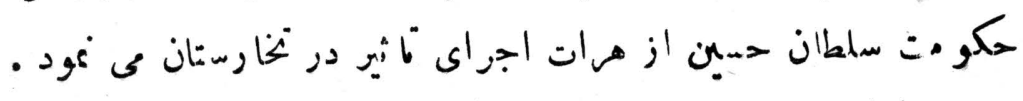

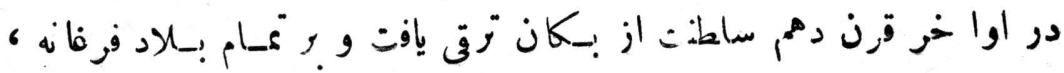

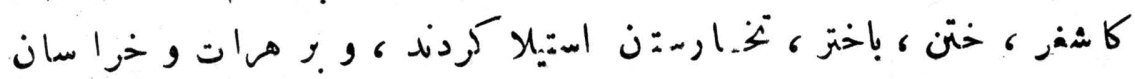

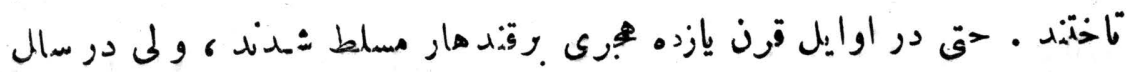

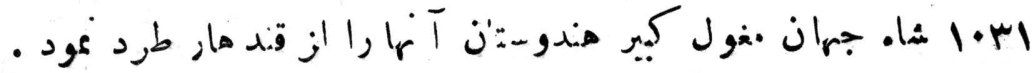

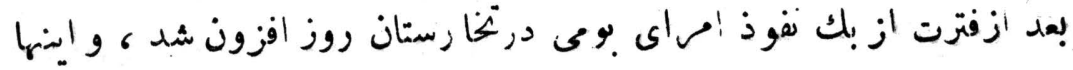

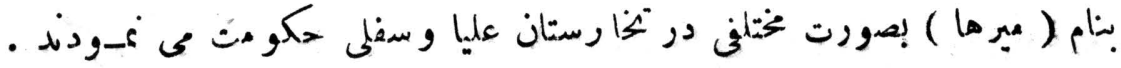

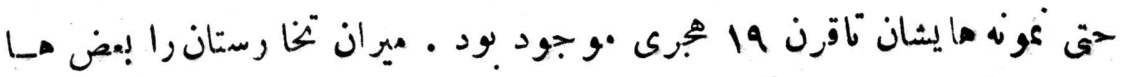

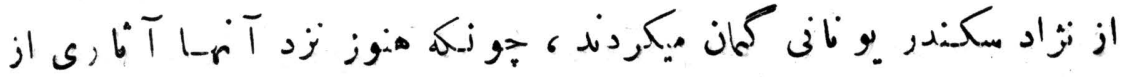

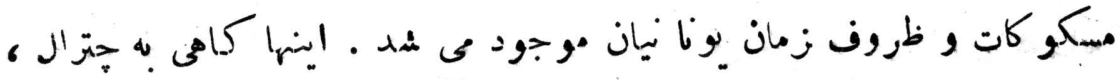

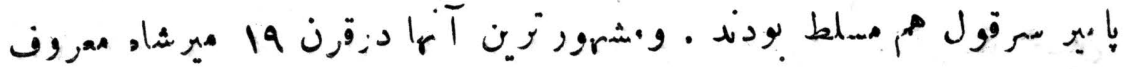
. ووده الست

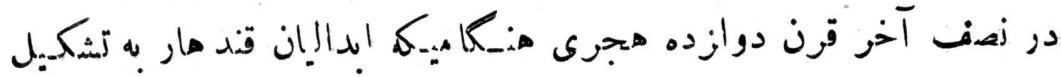

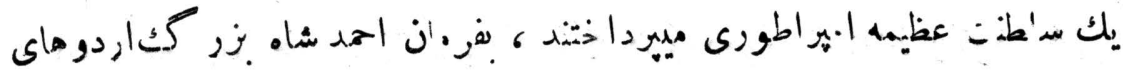

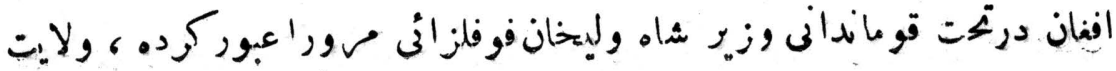


كوزكان ( ميهنه ، اند خوى شبر نان و غيره ) و بالخ وتخار هتان عليا و سفلى را

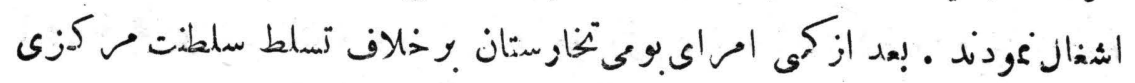

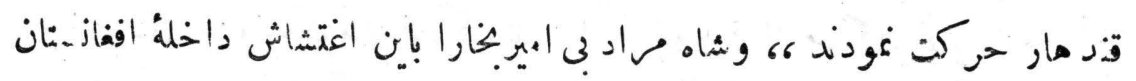

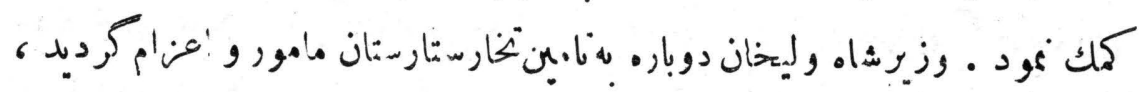

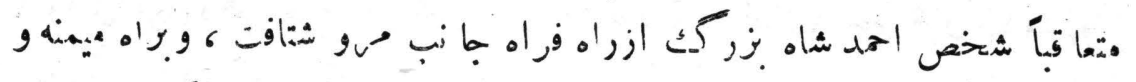

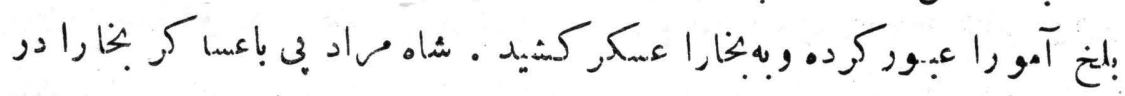

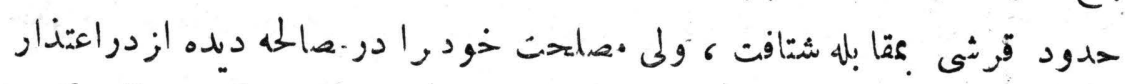

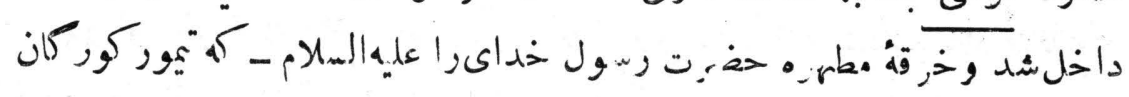

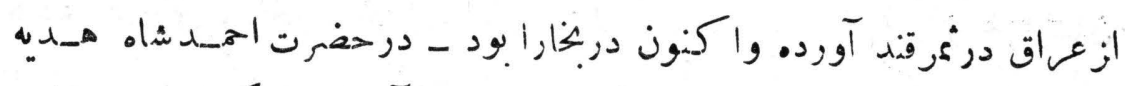

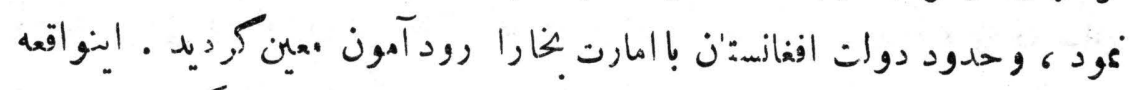

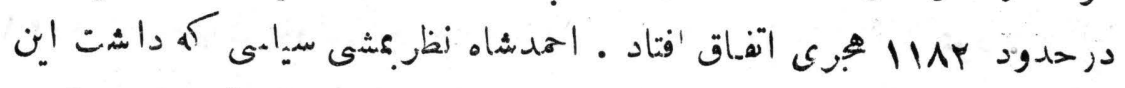

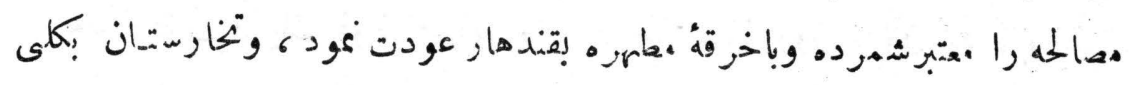

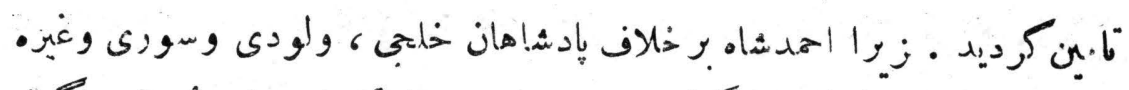

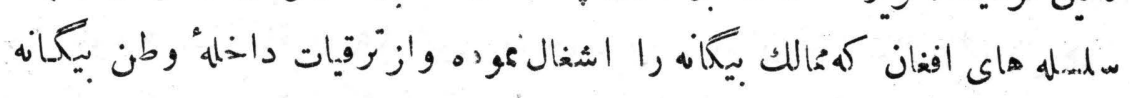

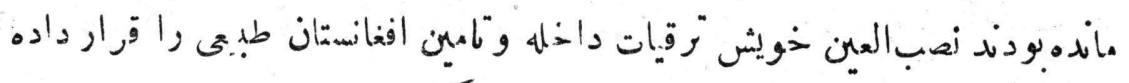

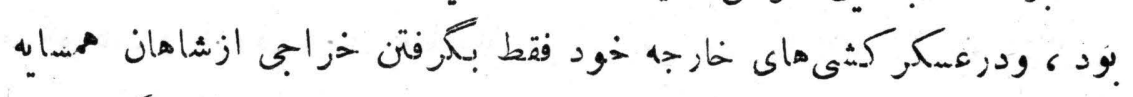

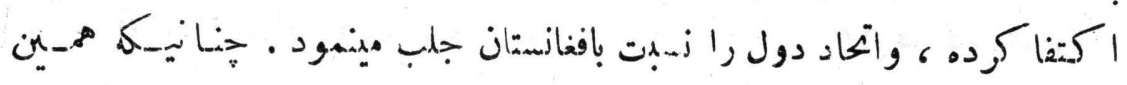

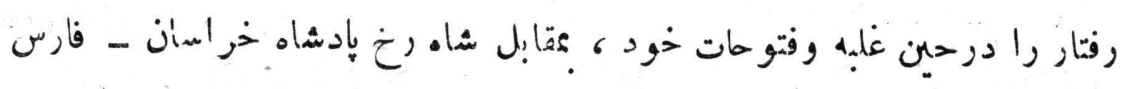

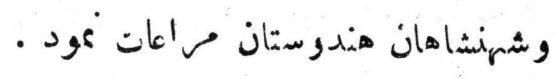

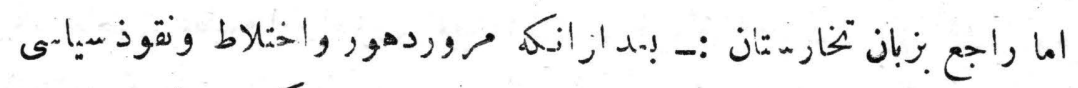

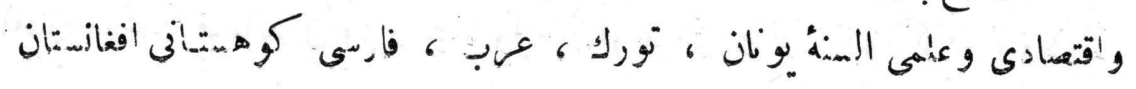




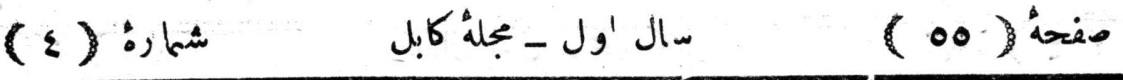

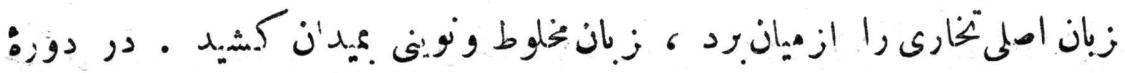

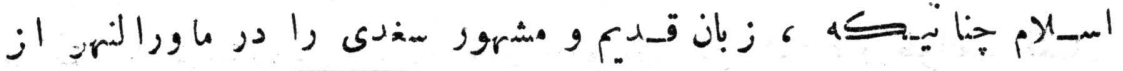

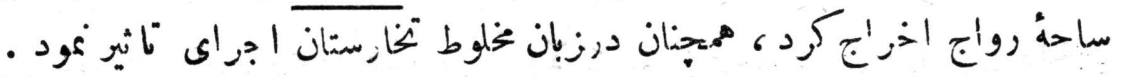

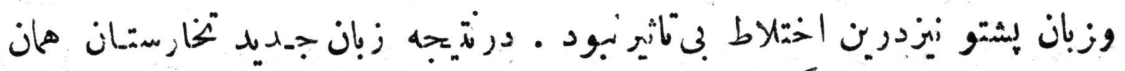

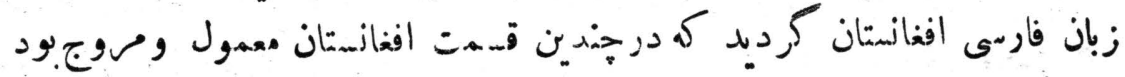

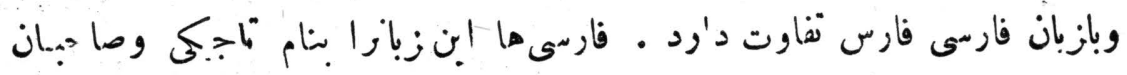

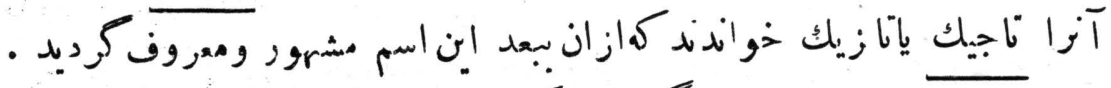

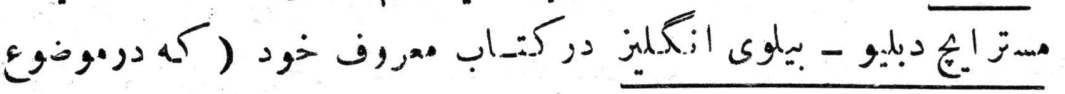

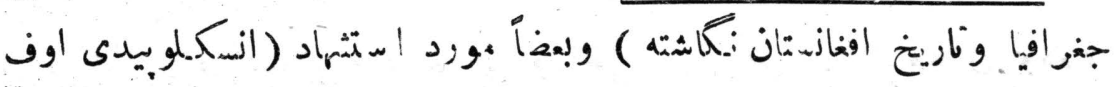

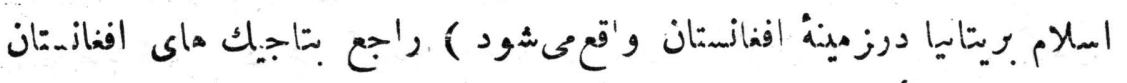

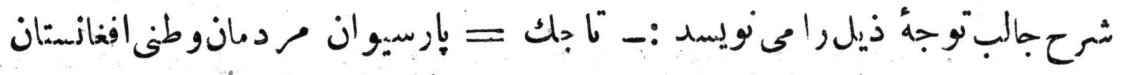

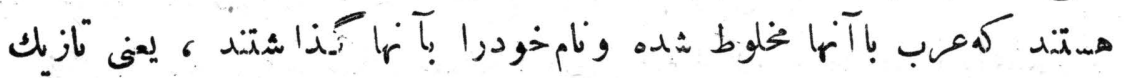

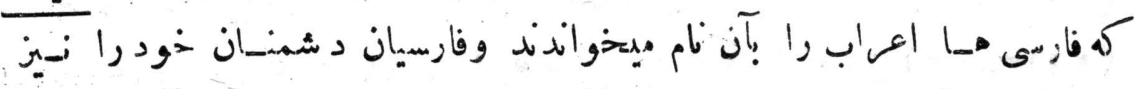

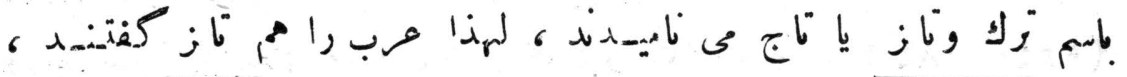

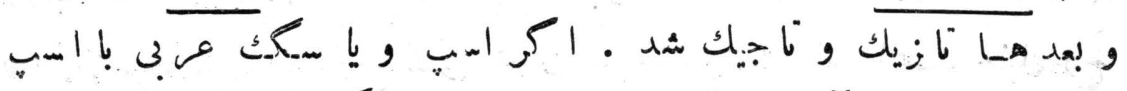

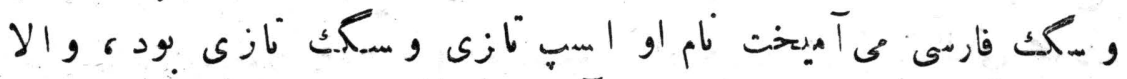

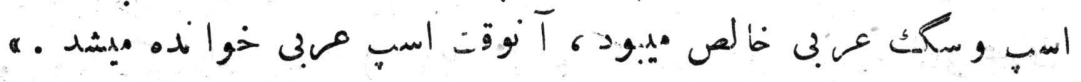

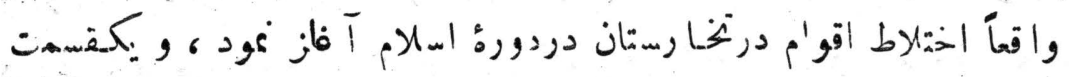

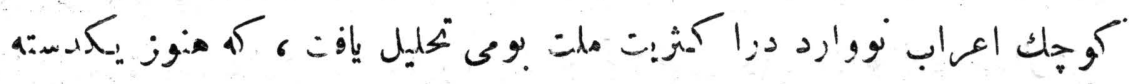

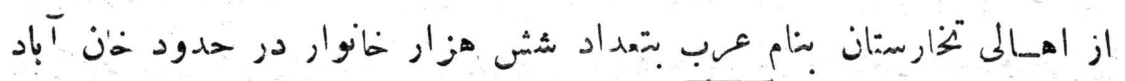

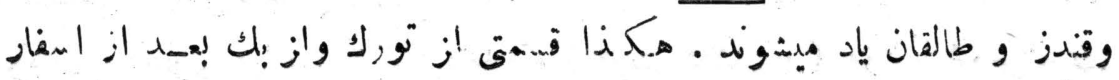


سال اول - مجله كابل

(01) 4xide

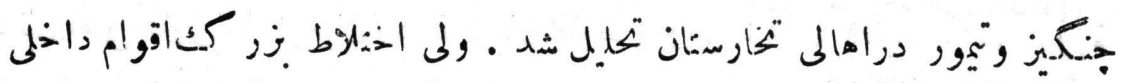

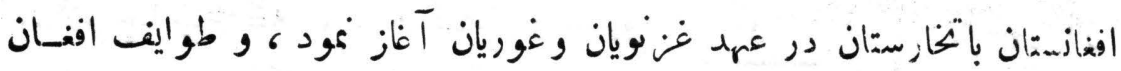

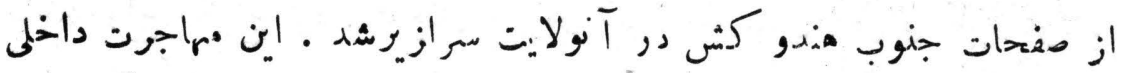

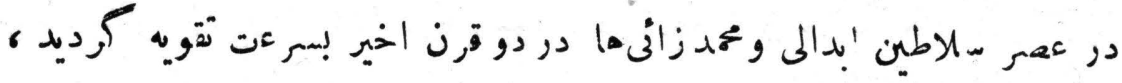

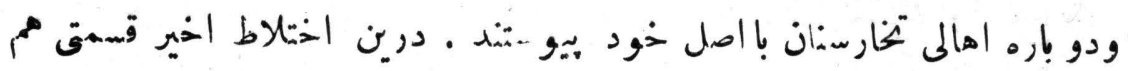

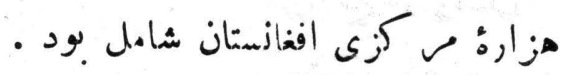

r.

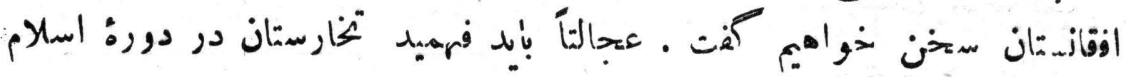

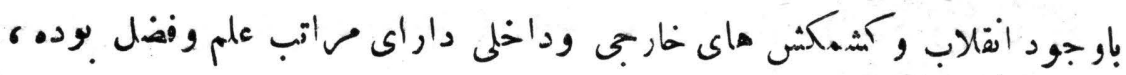

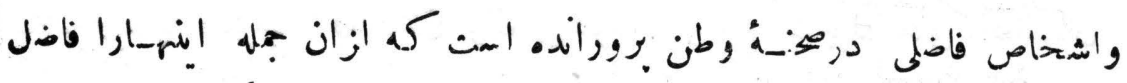

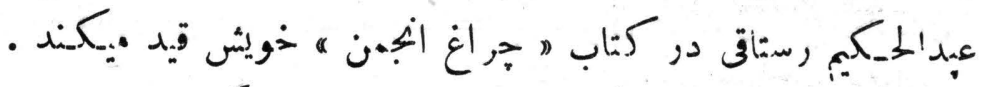

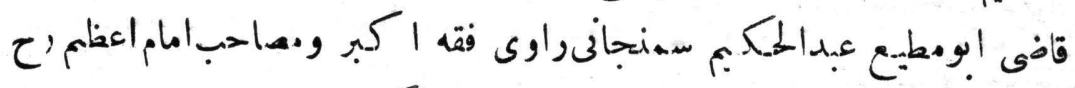

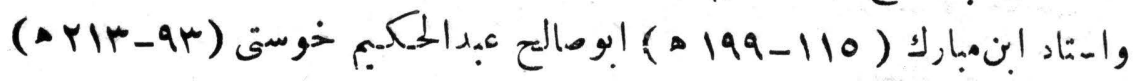

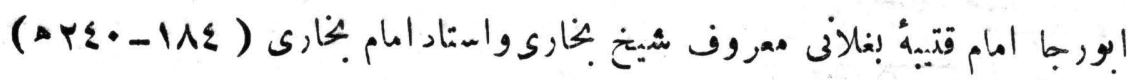

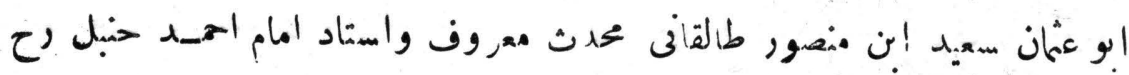

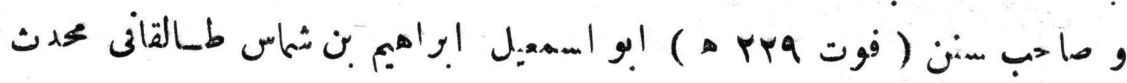

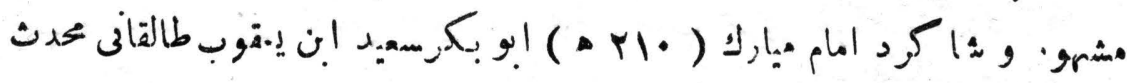

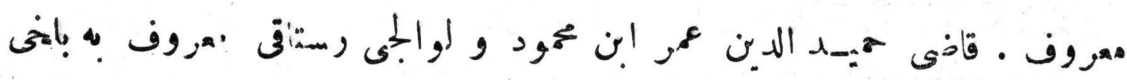

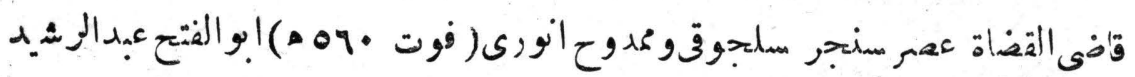

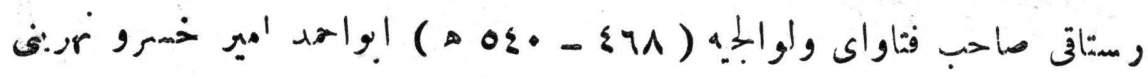

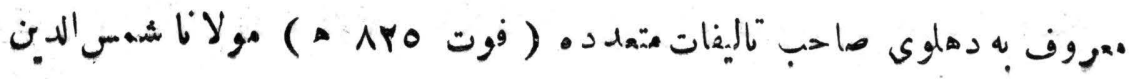




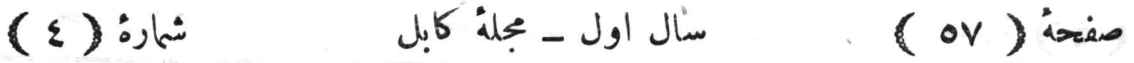

بغلانى جليس نظام الملك وزيومعروف درقرن ششم ـ شمسالدين شاعبدخشانى

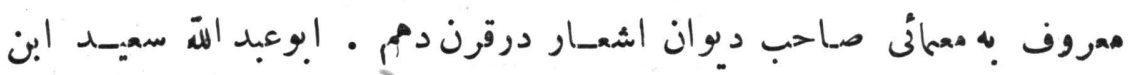

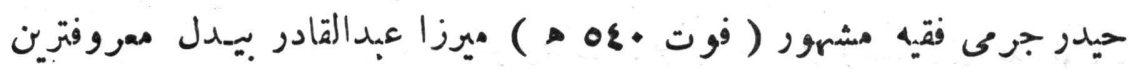

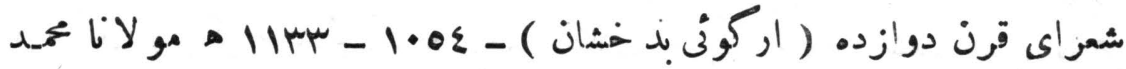

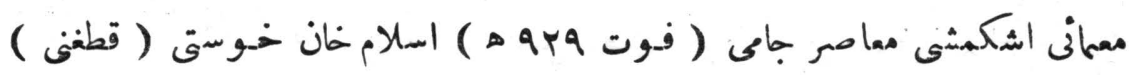

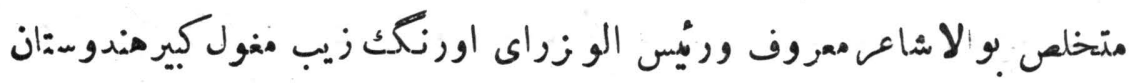

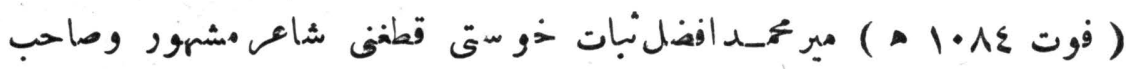

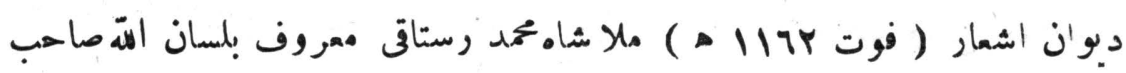

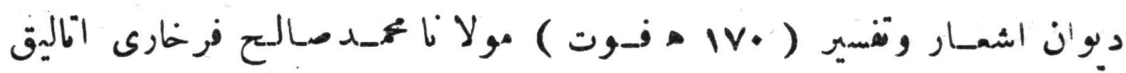

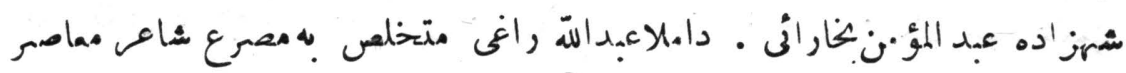

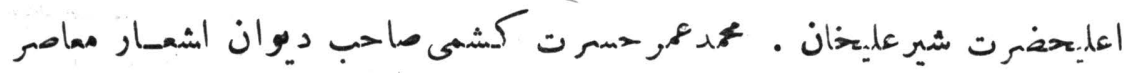

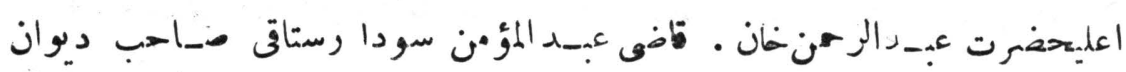

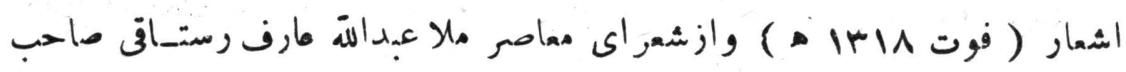

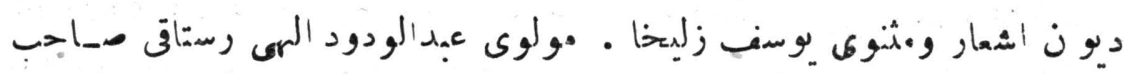

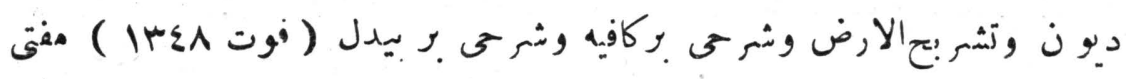

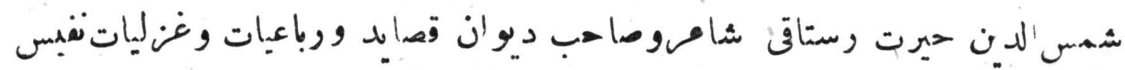

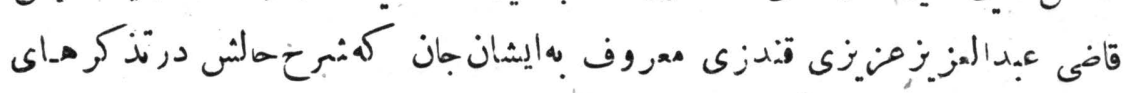

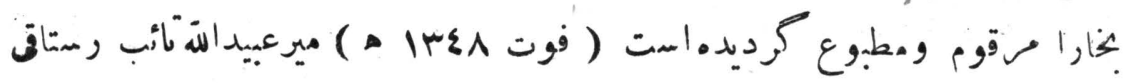

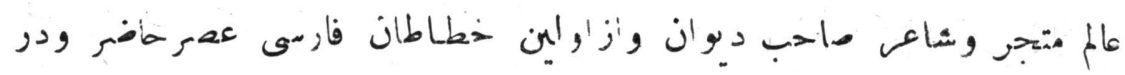

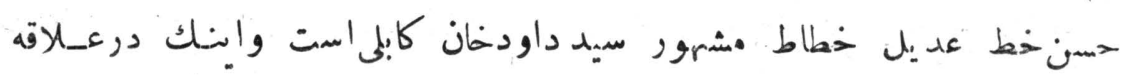


(ع) سال اول - بمجله كابل

(ON ) صer

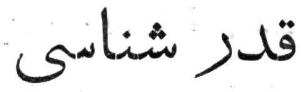

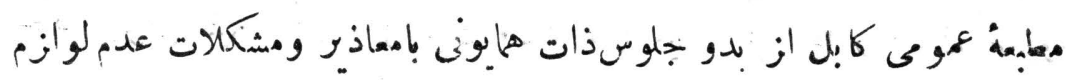

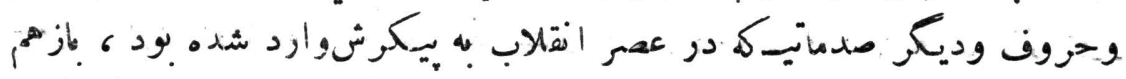

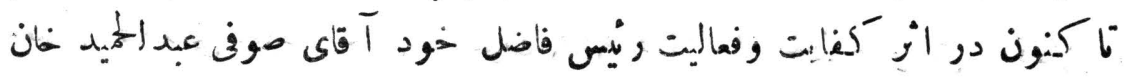

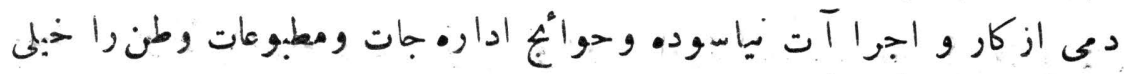

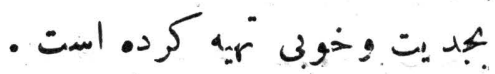

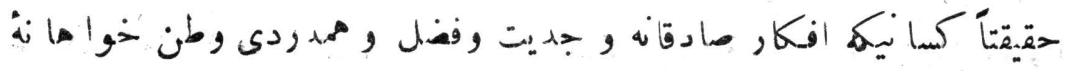

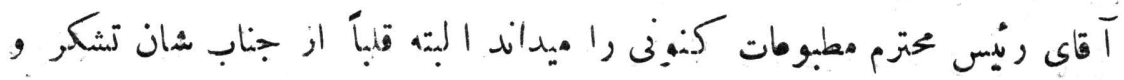

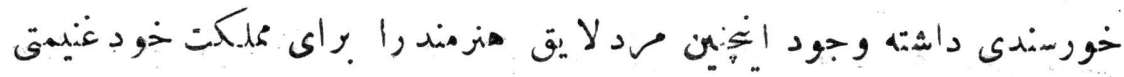
ميداند .

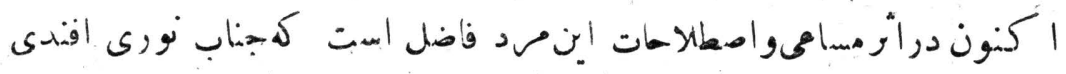

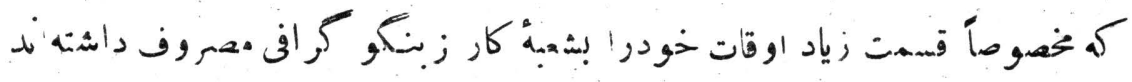

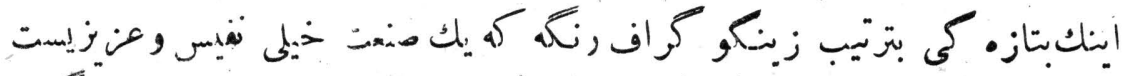

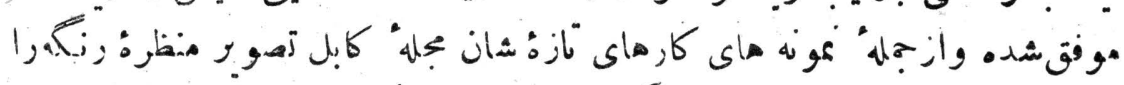

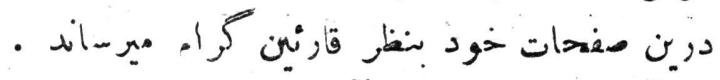

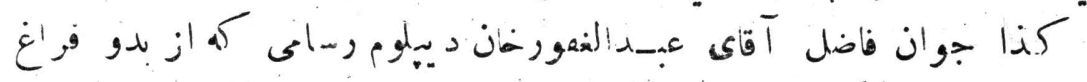

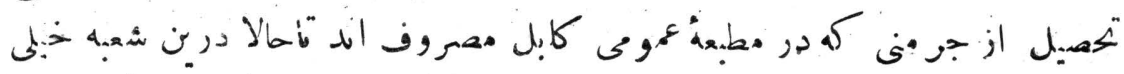

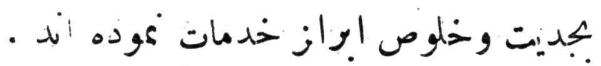

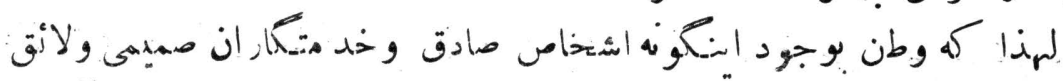

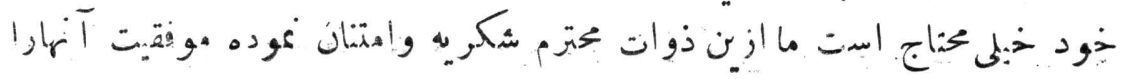
• 


\section{ياد آور و و يقشنهاد (2ACKU \\ $\$ 226$}

الجمن ادبى هون در زظر دارد صفحات مجله" كابل را بكضاهين

تاريخى وادبى وطن خزين سازد لذا : بنو يُسندكان محترم كه بتّ انند

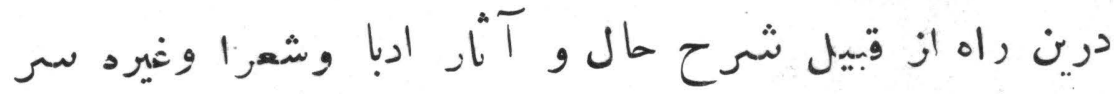

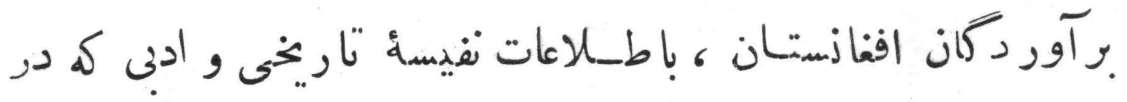
زواياى فرا موشى و زسيمان مد فون كرديده است خد متى نمايند يكدورؤ سالانه" مجلهُ كابل يا يك جلد كتياب نفيسى از طرف

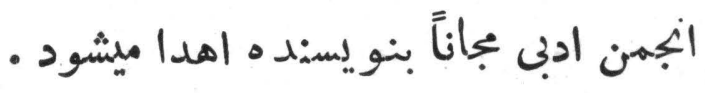

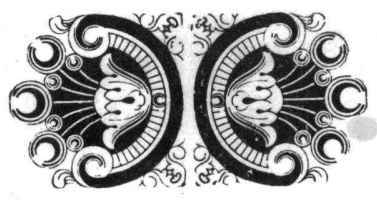

